\title{
WestVirginiaUniversity
}

THE RESEARCH REPOSITORY @ WVU

Graduate Theses, Dissertations, and Problem Reports

2016

\section{The Challenges Faced by New Science Teachers in Saudi Arabia}

Salman Alsharari

Follow this and additional works at: https://researchrepository.wvu.edu/etd

\section{Recommended Citation}

Alsharari, Salman, "The Challenges Faced by New Science Teachers in Saudi Arabia" (2016). Graduate Theses, Dissertations, and Problem Reports. 5089.

https://researchrepository.wvu.edu/etd/5089

This Dissertation is protected by copyright and/or related rights. It has been brought to you by the The Research Repository @ WVU with permission from the rights-holder(s). You are free to use this Dissertation in any way that is permitted by the copyright and related rights legislation that applies to your use. For other uses you must obtain permission from the rights-holder(s) directly, unless additional rights are indicated by a Creative Commons license in the record and/ or on the work itself. This Dissertation has been accepted for inclusion in WVU Graduate Theses, Dissertations, and Problem Reports collection by an authorized administrator of The Research Repository @ WVU.

For more information, please contact researchrepository@mail.wvu.edu. 
The Challenges Faced by New Science Teachers in Saudi Arabia

Salman Alsharari

\author{
Dissertation Submitted to the \\ College of Education and Human Services \\ at West Virginia University \\ in partial fulfilment of the requirements \\ for the degree of
}

Doctor of Education

in

Curriculum and Instruction

Patricia Obenauf, Ed.D, Co-Chair

James Rye, Ph.D., Co-Chair

Joy Saab, Ed.D. James Nolan, Ph.D.

John Oughton, Ed.D.

Department of Curriculum \& Instruction/Literacy Studies

\author{
Morgantown, West Virginia \\ 2016
}

Keywords: New teachers, science teachers, teaching challenges, teaching experience Copyright 2016 Salman Alsharari 


\title{
Abstract \\ The Challenges Faced by New Science Teachers in Saudi Arabia
}

\author{
Salman Alsharari
}

Growing demand for science teachers in the Kingdom of Saudi Arabia, fed by increasing numbers of public school students, is forcing the Saudi government to attract, recruit and retain well-qualified science teachers. Beginning science teachers enter the educational profession with a massive fullfilment and satisfaction in their roles and positions as teachers to educating children in a science classroom. Nevertheless, teachers, over their early years of practice, encounter numerous challenges to provide the most effective science instruction. Therefore, the current study was aimed to identify academic and behavioral classroom challenges faced by science teachers in their first three years of teaching in the Kingdom of Saudi Arabia. In addition, new science teacher gender, school level and years of teaching experience differences in perceptions of the challenges that they encountered at work were analyzed. The present study also investigated various types of support that new science teachers may need to overcome academic and behavioral classroom challenges. In order to gain insights about ways to adequately support novice science teachers, it was important to examine new science teachers' beliefs, ideas and perceptions about effective science teaching. Three survey questionnaires were developed and distributed to teachers of both sexes who have been teaching science subjects, for less than three years, to elementary, middle and high school students in Al Jouf public schools. A total of 49 novice science teachers responded to the survey and 9 of them agreed to participate voluntarily in a face-to-face interview. Different statistical procedures and multiple qualitative methodologies were used to analyze the collected data. Findings suggested that the top three academic challenges faced by new science teachers were: poor quality of teacher preparation programs, absence of appropriate school equipment and facilities and lack of classroom materials and instructional supplies. Moreover, excessive student absenteeism, student readiness to learn science and student lack of interest in science were the three most behavioral challenges encountered by beginning science teachers in the Kingdom of Saudi Arabia. Results also indicated that the perceptions of academic and behavioral classroom challenges may vary according to new science teacher gender, school level and years of teaching experience. More importantly, to become more effective science teachers, novice science teachers are expecting to receive more and better support from their schools. School principals and administrators should provide opportunities for beginning science teachers to attend effective new teacher orientation programs, use complete and well-developed curriculum materials with detailed sequence of teaching procedures, help in dealing with classroom management, and opportunities to participate in successful mentoring programs, coherent in-service training programs and regular professional development programs. Implications for Saudi Arabia government and policy makers, school principals and administrators, students and their parents were discussed and recommendations were made. 
The Challenges Faced by New Science Teachers in Saudi Arabia

Salman Alsharari

Dissertation Submitted to the

College of Human Resources and Education

at West Virginia University

in partial fulfillment of the requirements

for the degree of

Doctor of Education

in

Curriculum and Instruction

APPROVAL OF THE EXAMINING COMMITTEE

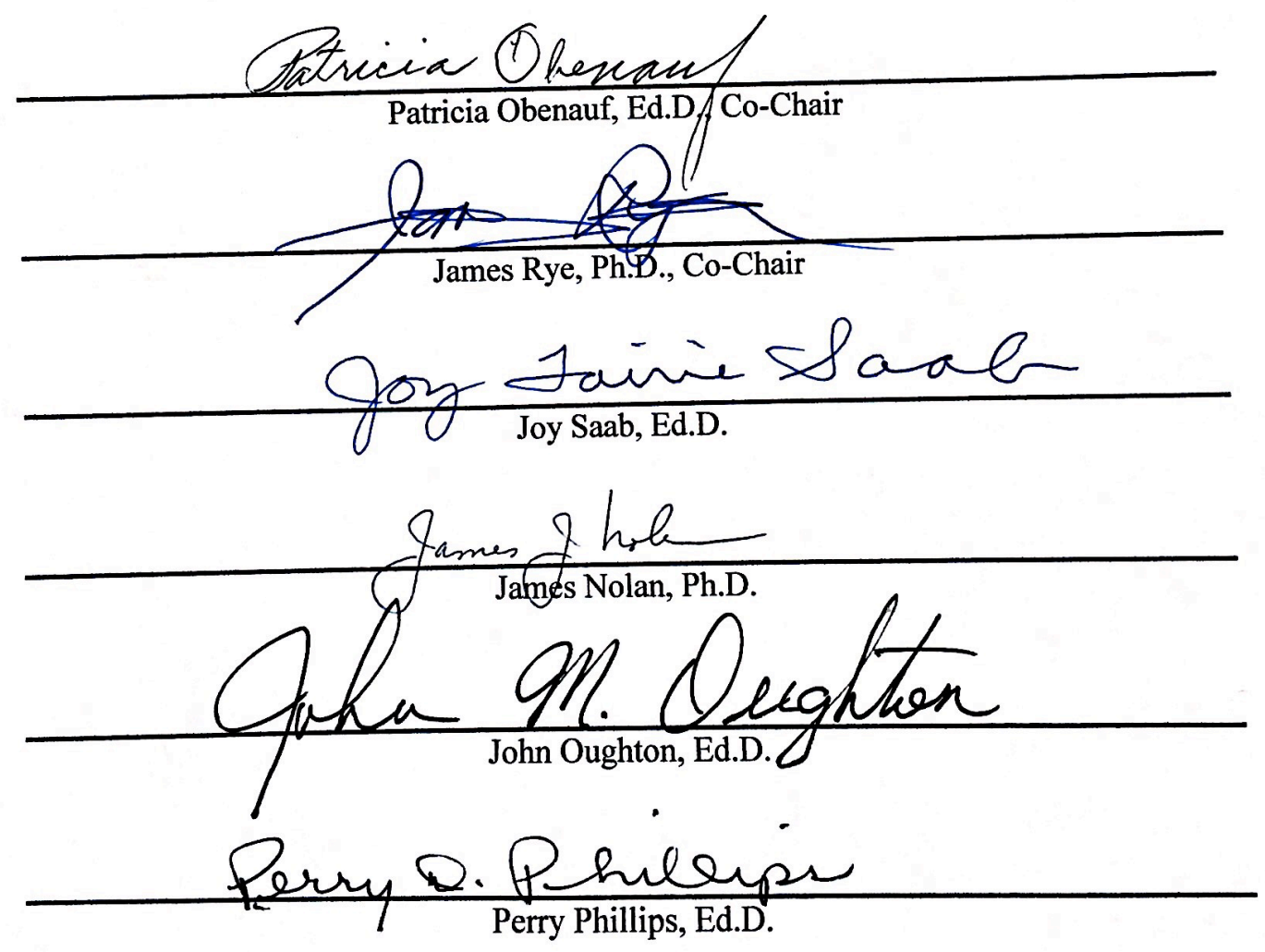

$\frac{12 / 11 / 15}{\text { Date }}$ 


\section{Dedication}

This work is dedicated to my parents and the rest of my family with deep love and tremendous gratitude for constantly supporting me and for encouraging me throughout my higher education career. 


\section{Acknowledgements}

I want to first acknowledge and thank ALLAH, the Most Merciful, the Most Gracious and Beneficent, who gave me the strength and courage to complete this work. I also want to thank my loving wife and my children for their love, patience, prayers and support during my graduate study.

I will be forever grateful to my dissertation committee chairperson, Dr. Obenauf, for her many years of support, assistance and clear guidance that have kept me grounded and motivated throughout my dissertation journey. My sincere thanks also go to my dissertation committee members Dr. Saab, Dr. Phillips, Dr. Nolan and Dr. Oughton for their thoughtful advice, enormous encouragement and insightful support.

I would like to express my deepest appreciation and heartfelt gratitude to my country Saudi Arabia Ministry of Higher Education for giving the opportunity to complete my studies in the United States of America. I feel very fortunate to be emotionally and financially supported by my country during my academic journey.

I would also like to thank my good friend, Dr. Raji AlSharari, for his encouragement in pursuing my doctoral degree and his continued support throughout the dissertation process.

In closing, I give thanks to all the science teachers who participated in this important research study. I appreciate their time, help, honesty and willingness to contribute to this research.

Thank you all so much! 


\section{Table of Contents}

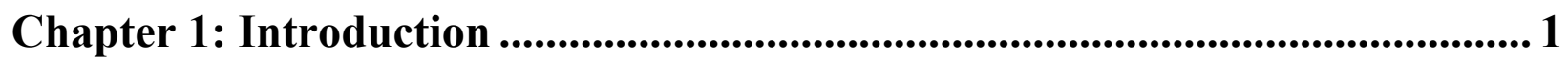

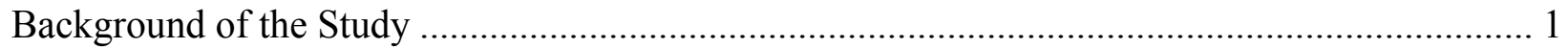

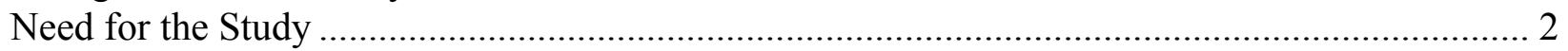

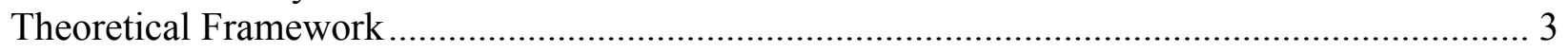

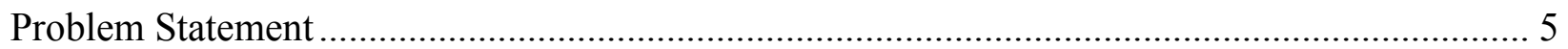

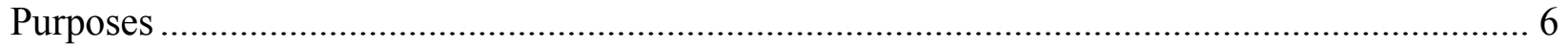

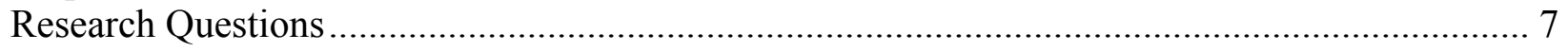

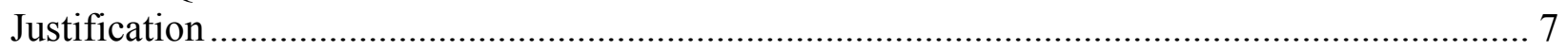

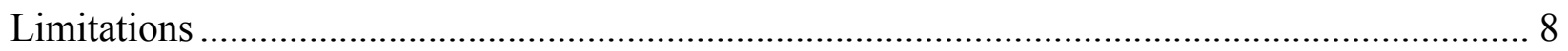

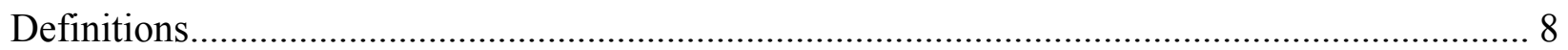

Chapter 2: Literature Review .......................................................................... 10

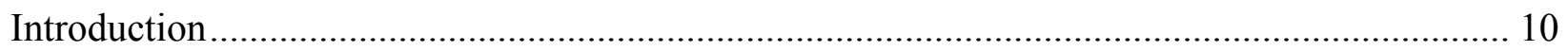

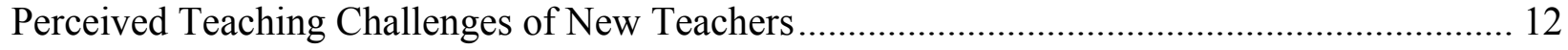

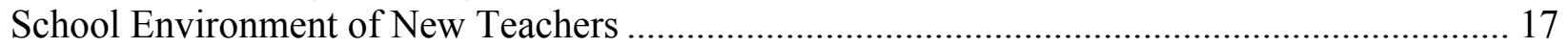

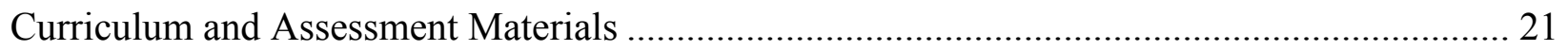

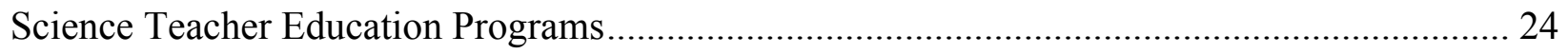

Characteristics of Highly Effective Science Teaching ..................................................... 27

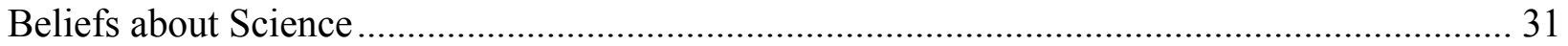

Chapter 3: Methodology................................................................................... 36

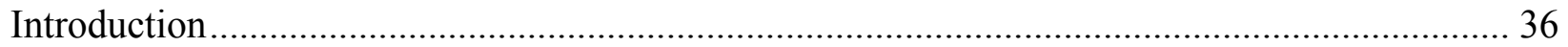

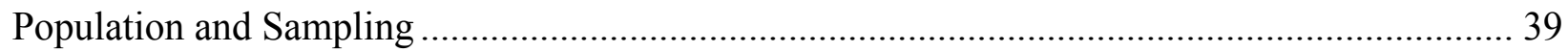

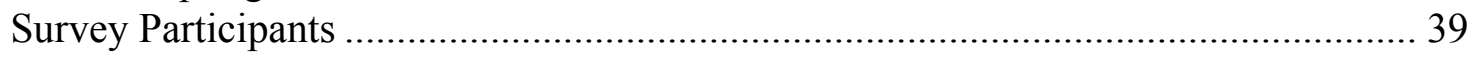

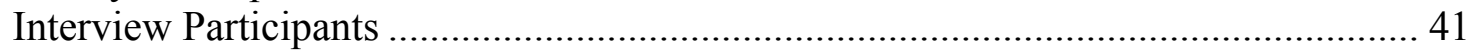

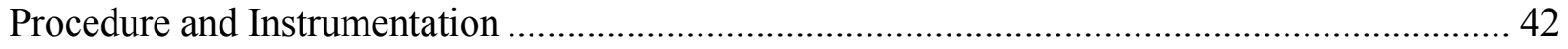

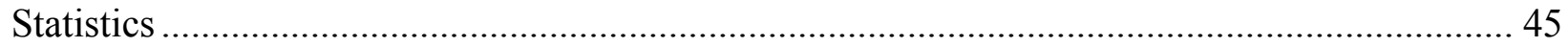

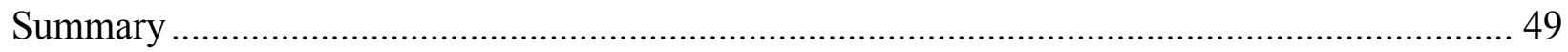

Chapter 4: Findings and Discussions ....................................................................... 51

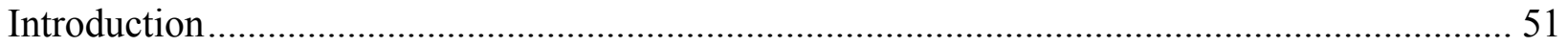

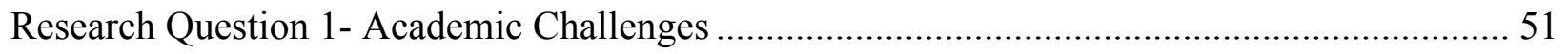

New Science Teacher Gender .......................................................................... 54

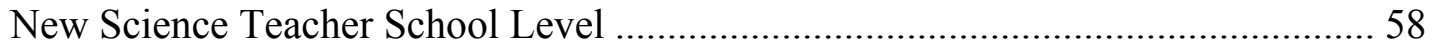

New Science Teacher Teaching Experience ........................................................ 63 
Research Question 2- Science Classroom Behavioral Challenges ………………..................... 67

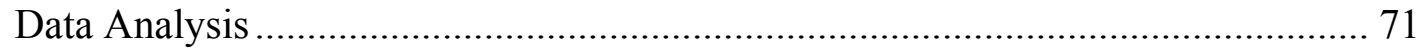

New Science Teacher Gender........................................................................ 71

New Science Teacher Teaching Experience........................................................... 74

New Science Teacher School Level ..................................................................... 80

Interaction Effects for the Factors Gender and Years of Experience ...................... 93

Interaction Effects for the Factors Gender and School Level................................ 100

Interaction Effects for the Factors Years of Experience and School Level........... 108

Research Question 3- New Science Teachers' Beliefs and Supports ........................................ 118

New science teachers' conceptions of effective science teaching ......................... 118

Identify and teach the core scientific ideas .................................................... 118

Connecting science content with students' interests and real life

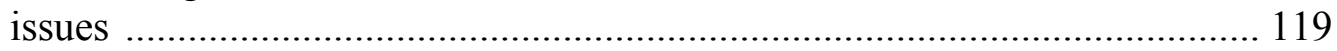

Using inquiry practices and getting hands-on experiences............................ 120

Cooperative and collaborative learning ...................................................... 121

Providing students with feedback by using multiple assessment

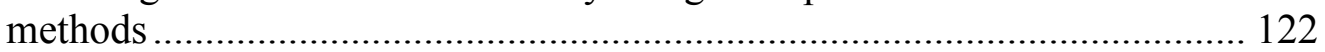

New science teachers' support programs......................................................... 123

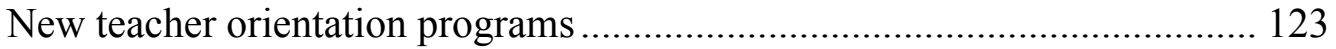

New teacher mentoring programs.......................................................... 124

Curriculum and Lesson Planning .............................................................. 125

Classroom Management and Discipline ………………............................ 126

Professional Development Programs ............................................................. 126

Chapter 5: Conclusions and Recommendations .......................................... 129

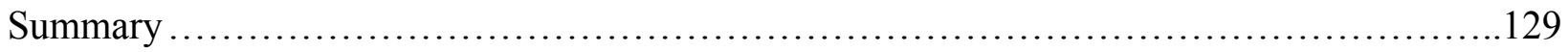

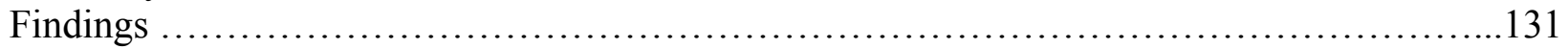

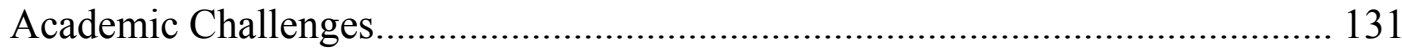

Behavioral Challenges …………………........................................................ 135

Beliefs and Supports ……………………………….............................. 140

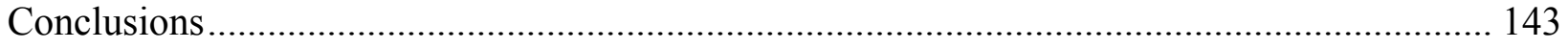

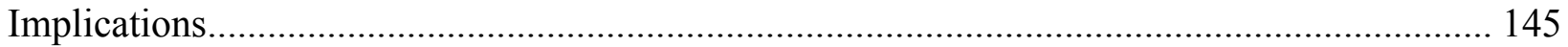

Saudi Arabia Government.......................................................................... 146

School Principals and administrators.................................................................. 146

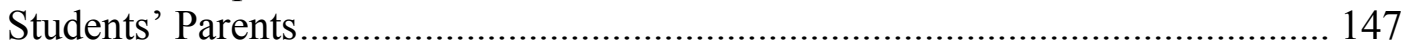

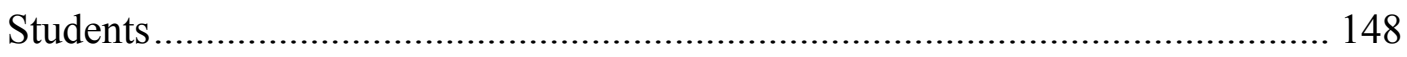

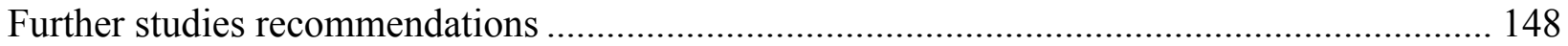

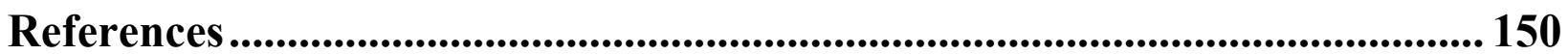

\section{Appendices}

A. Survey cover letter ............................................................................................ 163

B. Demographic survey questions ..................................................................... 164 
C. Academic challenges survey questions ....................................................... 166

D. Behavioral challenges survey questions .................................................... 168

E. Cover letter of invitation for interview ................................................169

F. Semi-structured interview questions ...................................................170

G. Semi-structured interview transcript.......................................................... 171 


\section{List of Tables}

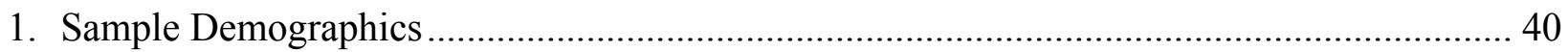

2. Summary of characteristics of the interview participants..................................................... 42

3. Total score and rankings of academic challenges faced by new science teachers.................... 52

4. Comparative score of academic challenges faced by male and female new science teachers . 55

5. Comparative rankings of academic challenges faced by male and female new science

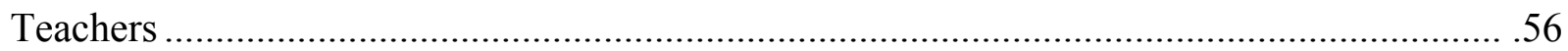

6. Mann-Whitney U Test results on difference of academic challenges faced by male and

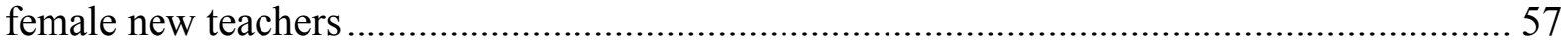

7. Comparative score of academic challenges faced by new science teachers in elementary, middle and high schools

8. Comparative rankings of academic challenges faced by new science teachers at the elementary, middle and high school levels

9. Kruskal Wallis H Test results on difference of academic challenges faced by new science teachers at the elementary, middle and high school levels

10. Comparative scores of academic challenges faced by first, second and third years new science teachers

11. Comparative rankings of academic challenges faced by first, second and third years new science teachers.

12. Kruskal Wallis H Test results on difference of academic challenges faced by first, second and third years new science teachers.

13. Means and standard deviations of science classroom behavioral challenges $67-68$

14. Means and standard deviations of science classroom behavioral challenges by gender ... 71-72

15. Independent $\mathrm{T}$ Test results on difference of science classroom behavioral challenges faced 
by male and female new teachers

16. Means and standard deviations of science classroom behavioral challenges by teaching

Experience..

$74-76$

17. ANOVA results on science classroom behavioral challenges and teaching experience ... 77-79

18. Means and standard deviations of science classroom behavioral challenges by school

Level

19. ANOVA results on science classroom behavioral challenges and school levels

20. Multiple pairwise comparisons of science classroom behavioral challenges faced by elementary, middle and high school new science teachers

21. Interactions between two factors: Gender and Experience.

22. Significance of Interactions between two factors: Gender and Experience $99-100$

23. Interactions between two factors: Gender and School Level $101-104$

24. Significance of Interactions between two factors: Gender and School Level $105-107$

25. Interactions between two factors: Experience and School Level $108-113$

26. Significance of Interactions between two factors: Experience and School Level $115-116$ 


\section{List of Figures}

1. Political Map of the Kingdom of Saudi Arabia .................................................................... 5

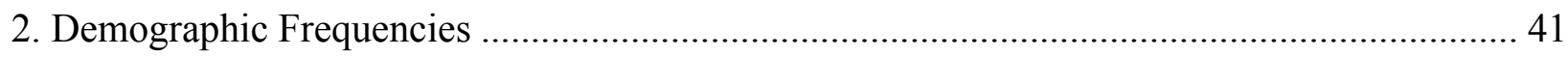

3. Effects of Independent variables on the dependent variable ............................................ 47

4. Interactions of Independent variables on the dependent variable ....................................... 48

5. Summary of Research Design and Methodology ...................................................... 50 


\section{Chapter 1: Introduction}

\section{Background of the Study}

Public education is seen as an essential ingredient of improving life quality and economic growth in many countries all over the world. The Kingdom of Saudi Arabia, along with other countries, believes that education is not only the most important investment a country can make, but also plays a key role in the development of human resources. It has allocated substantial resources to improve and develop its educational system because it prioritizes public education over all other issues. The state, the principal party in charge of education in the Kingdom of Saudi Arabia, guaranteed the right of education for all of its citizens by providing to them free education at every stage and branch of education. The Saudi Arabia's school system is gender segregated meaning that female teachers and administrators work exclusively with female students; whereas, male teachers and administrators work exclusively with male students. Overall, the school system services approximately 5 million students. The Kingdom is also committed to the supply of textbooks, equipment and facilities. Scholarships, financial aids and prizes are also given to deserving students. The Kingdom saw its tremendous efforts rewarded by achieving the two major goals set for 2015 during the Dakar Conference "Education For All" in 2000. These two goals were the eradication of illiteracy and the promotion of gender equality in public education.

Recent years have witnessed a simultaneous increase in student enrollment, due to the population growth in the Kingdom, and retirement of experienced teachers, resulting in a short supply of teachers in public schools. Several public schools in the Kingdom of Saudi Arabia are short 7,000 teachers in major subjects such as mathematics and science according to a study by the Saudi education ministry (Arab News, 2012). Additionally, the UNESCO Institute of 
Statistics (2006) suggested to the Arab states, mainly, Egypt, Morocco, Iraq and Saudi Arabia to expand their teaching force by almost $26 \%$ by 2015 to provide every child with primary education.

The Kingdom is looking for ways to improve the quality of the education system in order to meet the needs of the increasing number of students. One way to mitigate the effects of the shortage is to recruit and retain new teachers (McKinsey, 2007). The Kingdom of Saudi Arabia launches recruitment campaigns to highlight the gratification nature of teaching as a profession and proposes special recruitment incentives. Moreover, to make teaching more attractive, the Kingdom has increased the teachers' salaries and has provided scholarships for prospective teachers.

\section{Need for the Study}

Recruiting new science teachers is a short-term solution to the teacher shortage because of the low new teacher retention rate. Even the most developed country like the USA is still struggling with low retention rate of new teachers. In the USA, almost 50 percent of new teachers leave their profession within the first five years because of low salaries, poor working conditions, heavy workloads and lack of support (Achinstein, 2006; Bobbitt, Leich, Whittener, and Lynch, 1994; Darling-Hammond,1997). A high rate of new science teachers entering and leaving their jobs has particularly harmful implications on student achievement because it increases the cost for the government and creates instability in the educational system.

New science teachers leave their profession because they face more challenges than their more-experienced peers in achieving the goals set for them. "Exhilarated and exhausted, hopeful and cynical, fulfilled and dejected." With this statement, Liston, Whitcomb and Borko (2006) described the teachers' first year experiences. Pugach (1992) shared a similar view by stating 
that new teachers are vulnerable because they are neither secure nor confident. He described the first year of teaching for beginner teachers as a process which leads to the preservation of the existing state of classroom practice.

Moreover, Veenman (1984) identified eight major problems encountered by new teachers in their classrooms from the results of eighty-three studies conducted since 1960 by researchers on three different continents: America (United States of America, Canada and West Indies), Europe (United Kingdom, Netherlands, Switzerland and Finland) and Oceania (Australia). These major problems in rank order from the most encountered to the least by beginning teachers are:

(1) Classroom discipline, (2) motivating students, (3) dealing with individual differences, (4) assessing students' work, (5) relationships with parents, (6) organize class work, (7) lack of materials and supplies, and (8) dealing with individual students' problem.

This study is important because it provides a good opportunity to better understand the challenges that new science teachers encounter in their profession in the Kingdom of Saudi Arabia. Understanding new science teachers' challenges is the first step in helping them to overcome the challenges. In addition, this study discusses appropriate support and assistance that can be provided to the new science teachers.

\section{Theoretical Framework}

Snow, Griffin and Burns (2006) defined the progressive differentiation model as a process related to the professional development of teachers. They emphasize the relationship that exists between the five levels of progressive differentiation and the five points in the teacher career which are: (1) preservice, (2) apprentice, (3) novice, (4) experienced and (5) master teacher. The five levels of progressive differentiation are declarative, situated procedural, stable procedural, expert or adaptive and reflective/analyzed. Although the total knowledge of teachers 
grows across their career, the distribution of the levels of progressive differentiation changes with respect to various points of teacher's career. For example, preservice teachers, who were involved in learning new materials, were expected to acquire more declarative knowledge than novice or master teachers.

Fieman-Nemser (2001) designed a professional learning continuum from teachers' preparation to their early career years to help and improve the teaching process. Her continuum is defined as the central executive tasks instrumental in the process of teacher preparation, new teacher induction and early professional growth. It takes five major steps to be prepared as teacher: (1) analyzing beliefs and forming new vision, (2) developing subject-matter knowledge, (3) developing understandings of learners and learning, (4) developing a beginning repertoire, and (5) developing the tools to study teaching.

Porter and Brophy (1988) described a model of good teaching that identifies several factors influencing teachers' instruction of their students in particular content. They defined a good teaching concept as a rational process in which the teachers' development of professional pedagogical knowledge and routines are influenced by background and milieu factors. Moreover, teacher knowledge, in turn, enhances instructional planning and affects the nature of instruction. As a result, this instruction combined with student aptitude and motivating factors affect students' immediate responses to instruction. The model of good teaching has a self-correcting mechanism in which the feedback received from students influences teacher reflection. This, in turn, improves teachers' professional knowledge and their planning of instruction. Furthermore, the model of good teaching provides students with the opportunity to learn and master metacognitive strategies. Good teaching requires not only knowledge of subject matter but also the need and appropriate use of: (1) characteristics of class (students, resources), (2) external 
factors (policies, people, instructional materials, social norm), (3) teachers' personal experiences and professional education, and (4) teacher reflection. This shows that effective teaching can be influenced by the challenges that the teacher faces and the support that they receive which the research questions will address in this study.

\section{Problem Statement}

The Kingdom of Saudi Arabia is an Arab country, located in the west of the Arabian Peninsula on the Persian Gulf, bordering United Arab Emirates, Bahrain and Qatar to the east, Yemen to the south, Oman to the southeast, Kuwait to the northeast, as well as sharing borders with Iraq and Jordan to the north. The kingdom consists of 13 provinces: Al Jouf, Northern Borders, Tabuk, Hail, Al Madinah, Al Qasim, Makkah, Al Riyadh, Eastern Province, Al Bahah, Asir, Jizan and Najran. See Figure 1.

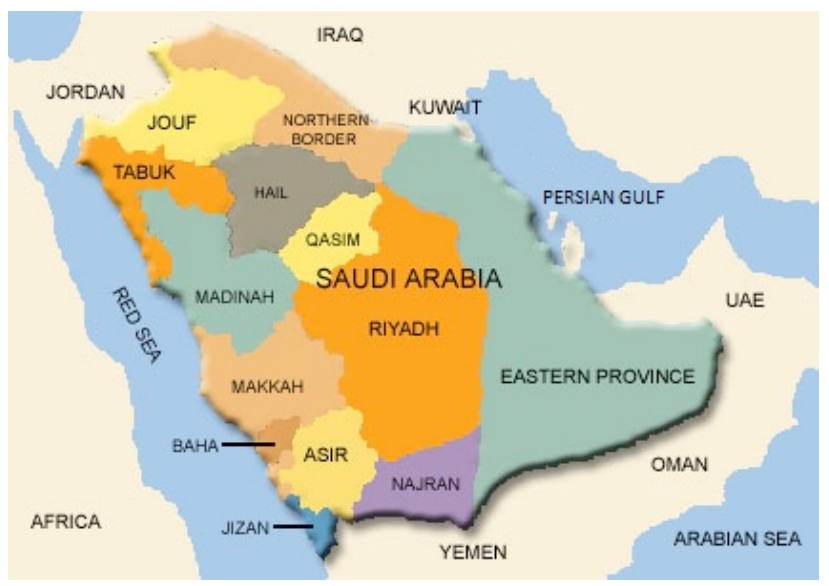

Figure 1: Political Map of the Kingdom of Saudi Arabia

Located in the north of the Kingdom of Saudi Arabia, Al Jouf has a population of 440,009 according to the 2010 census and a land area of $100,212 \mathrm{~km}^{2}$. It is divided into three governorates: Sakakah (the capital city of the province), Qurayyat and Dumat Al-Jandal. Al Jouf is known as one of the most important grazing and agricultural ground in the Kingdom of Saudi Arabia because of its abundance of underground water. The fertile agricultural land of the 
province makes it possible for farmers to cultivate olives, citrus, yellow corns, potatoes, dates, onions and wheat.

However, Al Jouf failed to develop and modernize over a short period of time. During the last decade, the Saudi government invested heavily in the economy and infrastructures of the province of Al Jouf leading to the creation of more jobs, including science teachers. With the creation of several new public elementary, middle and high schools in the province of Al Jouf, the demand for science teachers significantly increases. New teachers enter the education profession with a massive fullfilment and satisfaction in their roles and positions as teachers to educating children in a classroom. Indeed, by engaging in effective science teaching in a classroom, teachers can assist students to deepen their conceptual understandings, inquiry abilities and problem-solving skills.

Nevertheless, over their early years of practice, teachers encounter numerous challenges to provide the most effective science instruction. For example, preservice science teachers may lack subject-matter knowledge as well as pedagogical content knowledge. This study is mainly focused on the major current challenges in teaching science faced by new teachers in the province of Al Jouf in the Kingdom of Saudi Arabia. Furthermore, numerous solutions to the problems encountered by new science teachers in Aljouf are discussed in the present study.

\section{Purposes}

The growing population of students in Saudi Arabia brings increasing demands for additional school buildings, educational resources and teachers. In fact, Saudi Arabia faced a shortage of qualified teachers in subjects like science, technology, engineering and mathematics. To address this issue, Saudi government is recruiting more beginning science teachers across all the provinces of the kingdom. New teachers entered the teaching profession with a feeling of 
excitement and massive commitment to making a difference in the lives of their students. They hold a romantic and idealistic view about the role of teacher and strategies to impact students' lives. However, after several weeks of work and stress, beginning teachers realized that their professional lives are not going according to plan. They faced many various challenges in their early classroom years when they must teach effectively at their workplace. The present study has three main goals: to identify and better understand the academic challenges that new science teachers faced in the Kingdom of Saudi Arabia, to determine the behavioral challenges that new science teachers encountered in their classrooms, and to investigate new science teacher beliefs about effective science teaching and their perceptions regarding the support they received from their schools.

\section{Research Questions}

In this study, three research questions were addressed. The research questions used in this study are as follows:

Research Question 1: What are the academic challenges that new science teachers face in the Kingdom of Saudi Arabia?

Research Question 2: What are the behavioral challenges encountered by new science teachers in their classrooms?

Research Question 3: What are new science teachers' perceptions of effective science teaching and teacher support?

\section{Justification}

This study provides the opportunity to determine and better understand new science teachers' challenges. Numerous studies described several challenges new science teachers 
encounter in their classroom. However, very little of the available research looked specifically at the challenges of science teachers in their first three years of teaching in the Kingdom of Saudi Arabia. The participants in this study expressed their opinions and shared their views and beliefs about effective science teaching and challenges in the teaching profession.

\section{Limitations}

One of the major limitations of the study is that it only involved new science teachers who work in Al Jouf, a province of the Kingdom of Saudi Arabia. The study did not include new science teachers located in the remaining provinces of Saudi Arabia. Moreover, the number of new science teachers who participated in the study was not large enough to ensure statistically representative sample size and external validity of the results. Therefore, the findings of the study represent only the opinions and views of Al Jouf new science teachers who were surveyed and cannot be generalized to other provinces.

It is important to note that this study focused on new science teachers' challenges; thus new teachers in other subject areas were not interviewed. Although the content of science teacher preparation programs in the Al Jouf region of the Kingdom of Saudi Arabia was investigated, the teaching materials themselves used in these programs were not studied.

\section{Definitions}

1. Challenge: Challenge is defined as a test of someone's abilities, skills and resources in a professional environment which is demanding but stimulating. It is also used here as a matter or any situation that invites decision, resolution and solution.

2. Science: The word science comes from the Latin word "scientia" meaning "knowledge." Therefore, science is defined as a branch of knowledge or principles gained by the study of the nature and behavior of the material and physical universe. It is the investigation of natural 
phenomenon based on observation, experiment and measurement followed by the formulation of laws to describe the phenomenon.

3. New teacher: A new teacher is, by definition, a teacher who recently graduated from teacher preparation program without professional experience or someone who has been teaching only for one, two or three years. He or she is new to the profession and works toward expertise.

4. Science teacher- Elementary, middle and high school teacher who teaches a particular branch of science such as earth science, health, biology, chemistry or physics.

5. Teaching- Teaching is an activity that consists of helping students construct meaning and come to an understanding of important ideas and processes. 


\section{Chapter 2: Literature Review}

\section{Introduction}

Humans have always showed the desire to better understand and interact with the world around them by making observations, asking questions and seeking answers. To accomplish this goal, the inherent restlessness of the imaginative human mind has engaged in the process of scientific inquiry by designing and carrying out investigations, making relationships between evidence and explanations and building conceptual models. This attempt to explore, examine and explain the natural world, including biology, physics, chemistry, geology is science.

Science plays a key role in the world because it helps people to improve their life quality at many different levels and to get out of poverty, superstition and ignorance. Science instruction provides students with the opportunity to know and learn about living organisms, non-living matter, energy, space and events that occur in their daily lives, to develop scientific attitudes such as humility, responsibility, curiosity, objectivity and intellectual honesty, to generalize and discover scientific principles. The interests and needs of the students, their level and development and desires must lie at the heart of the science teaching process. In other words, it is necessary for science teachers to make every science lessons meaningful by establishing a link between their students personal life experiences to science. In addition, science teachers need to have sufficient subject-matter knowledge and pedagogical content knowledge to be effective teachers of science (Shulman, 1986; Vasquez, 2008). Knowledge of educational contexts, knowledge of learners and their characteristics, knowledge of learning goals and knowledge of principles and strategies of classroom management and organization define the teacher subjectmatter knowledge. Content knowledge, curriculum knowledge and understanding of teaching profession address general dimensions of teacher pedagogical content knowledge. 
When entering the teaching profession, the majority of new science teachers are highly motivated, excited and desire to be successful teachers because of their love and passion for teaching. After several months, most beginning teachers experience doubt and fear about their teaching skills and their students learning ability because they are confronted with several new events and a variety of problems and situations. Conway (2001) and Sabar (2004) have confirmed by their studies that the novice teachers' illusions, their despair and their sense of loss and grief stem mainly from the differences between new teachers' expectations and the first year of school reality. As a result of frustration in the teaching profession, many promising beginning teachers leave. Without appropriate support and an effective plan for support, the early years of teaching are described as a "sink or swim" experience (Bartell, 2005; Reiman \& Paramore, 1994). Given the same responsibilities as their more experienced colleagues, beginning teachers can experience difficult and challenging work.

The objective of the literature review is to examine and discuss the research that has been done related to the challenges faced by new science teachers. Indeed, several scholars have provided evidence that beginning teachers face numerous challenges in their profession. Davis, Petish and Smithey (2006) searched for papers related to the challenges faced by new science teachers in seven journals: American Educational Research Journal, Journal of Research in Science Teaching, Journal of Science Teacher Education, Journal of Teacher Education, Journal of the Learning Sciences, Science Education and Teaching and Teacher Education. They identified several challenges faced by new science teachers and grouped them into five main themes: (a) challenges related to understanding the content and disciplines of science, (b) challenges related to understanding learners, (c) challenges related to understanding instruction, (d) challenges related to understanding learning environments, and (e) challenges 
related to understanding professionalism.

The literature review summarizes and gives an overview of concerns and problems encountered by science teachers in their first three years. The challenges faced by new science teachers are usually perceived as obstacles to effective teaching. Therefore, the characteristics of effective science teaching and effective science teachers are also discussed.

\section{Perceived Teaching Challenges of New Teachers}

In addition, the most frequent challenges and difficulties encountered by new teachers reported by much of the research and literature (Corcoran, 1981; Fuller, 1969; Gold, 1996; Reeves \& Kazelkis, 1985) are: (a) classroom management, (b) knowledge of administrative routines and procedures, (c) good understanding of a particular school philosophy, (d) building and sustaining relationships with colleagues and parents, (e) strong subject matter knowledge, and (f) effective use of instructional, curriculum and assessment materials.

Several studies have also revealed that when teachers entering the profession, they have the following major concerns: (a) how to set up their classroom, (b) how to prepare for the first weeks of school, (c) what to expect from the curriculum, and (d) what are their salary and benefits (Britt, 1997; Ganser, 1999; Mandel, 2006). Drummond (1991) investigated the work performance and preparation of new teachers. Four-hundred new teachers who recently graduated from the University of Florida, participated in the study. The study indicated that these students were facing challenges in the following areas: teaching skills, knowledge of the subjects, computer and questioning skills, lesson planning, motivating students and dealing with paperwork. Teaching skills which include classroom management and preparation of materials for the teaching process were the most mentioned problems.

Evans and Tribble (1986) identified and compared the challenges faced by teachers in 
their first two or three years of teaching with those faced by teachers in their first year of teaching in the studies reviewed by Veenman (1984). They found that both groups of teachers stress problems with motivating students and dealing with individual learners differences. The most serious problem perceived by beginning teachers is classroom discipline, followed by assessing students' works and relationship with parents. In contrast to beginning teachers, preservice teachers gave significantly higher problem seriousness ratings for knowledge of subject matter, organization of class work and dealing with individual differences.

According to Connelly and Dienes (1982) and Shulman (1987), the major challenges faced by new teachers arise from the need to adjust, adapt and become familiar with the organizational norms, symbols and internal ethical and cultural codes of the school. In too many cases, when new teachers enter their new school, they are often confronted by conflicts between their employment rules and their beliefs. The confrontations are major causes for a lack of selfconfidence and the social marginality of new teachers. The outcome of marginalization of new teachers is that the affected teachers, who faced major challenges, do not seek professional help from others.

Teachers also faced behavioral challenges within the classroom environment. Owaidat and Hamdi (1997) examined the behavioral problems of 1907 male students in $8^{\text {th }}, 9^{\text {th }}$ and $10^{\text {th }}$ grade from several public schools in Jordan. The information was collected by questionnaire. The results of the study show that students were exhibiting the following negative behavior at higher frequency: quarrels and fight between students; cheating during in-class examinations; and student lateness to morning classes.

Sabar (2004) investigated the transition and adaptation process of beginning teachers to the teaching profession in Israel by interviewing 46 novice teachers during their first and second 
year of teaching. He pointed out that the process of adjustment of novice teachers to the teaching profession and to school culture can be compared to the main stages of socialization of immigrants when coming into a new country. There are some remarkable emotional similarities between novices and immigrants groups such as the hopes and expectations, the illusions and the crises. Like immigrants who are expecting better life conditions and financial success from the host country, new teachers enter classrooms with hopes and dreams to achieve success for themselves as teachers and for their students. Very soon after being confronted with real life, new teachers and immigrants experience a reality shock or cultural shock and frustration leading to an inescapable sense of feeling failure and desperation about themselves. While Veenman (1984) defined reality shock as the feeling experienced by new teachers when reality does not match their expectations, Oberg (1972) defined the feelings experienced by immigrants as a result of the cultural difference between their home and host countries. Despite similarities between new teachers and immigrants, there are some striking differences between the two groups which provide a source for hope. In an instrumental and supportive school environment, new teachers can develop their knowledge, skills and ability to become expert and good teachers within a short period of time compared to immigrants who may experience the culture shock over a long period. Furthermore, unlike the immigrants who do not have any means and tools to prepare them to overcome culture shock of the new country, new teachers can avoid school culture shock by having a better preparation through induction, mentoring and training programs.

Le Maistre and Pare (2010) compared the experiences of beginning practitioners of four professions: teaching, occupational therapy, physiotherapy and social work during their final of year field training and first of professional practice. The findings indicate that all the students of 
the four professions under investigation received considerable support during their final year of field training. Beginning teachers, however, were treated differently than the neophyte practitioners in occupational therapy, physiotherapy and social work during their first year of professional practice. Novice teachers failed to get appropriate, adequate and necessary support from their experienced colleagues or school management team during their first year of teaching. Unlike novices in other professions, teachers are expected to introduce into the schools the most recent methods they acquire in the teacher education institution. In addition, new teachers are excepted to affect an individual student's socialization process from the first day of school. As a socialization agent for students, teachers have responsibility for providing knowledge, skills, rules and social settings values for their students. In some cases, new teachers are asked to teach a large number of students with negative attitudes and educational difficulties. However, many beginning teachers do not have a repertoire of strategies to make decisions in a timely manner in order to solve problems that occur during their classroom. They also do not possess a collection of knowledge states to deliver instructions effectively while dealing with recalcitrant students by establishing order in the classroom. Another difference between teaching and other professions is the workload assigned to novices teachers in their initial period of practice which is similar to the one assigned to their experienced colleague without giving them any organized supports. A great deal has been written about factors explaining the increase in the workload of new teachers: (a) Society has higher expectations of teachers and offers to them lower recognitions, (b) promotion of high level of accountability to parents and policy-makers, (c) numerous changes made in the instructional and curriculum materials in a short period of time, (d) Rapid growth in the use of computer technology as instructional tools in school, (e) Extension of teacher's role beyond classroom walls, (f) student population is more diverse, 
and (g) increased the amount of administrative work (Dussault et al., 1999; Goodlad, 1984; Hagreaves, 1992; McLagan, 1999; Nias, 1989).

Furthermore, Meister and Melnick (2003) examined the perceptions of 273 new teachers across the United States as they moved from pre-service to in-service training and identified the three greatest difficulties encountered by these novice teachers: (a) dealing with individual differences and needs of students, (b) managing timetables and the complexity of workloads, and (c) maintaining a good relationship with parents.

After surveying and interviewing 86 graduates of the two years graduate pre-service teacher education program from 2004 to 2006 in Ontario about their experiences as a new teacher, Fantilli and Mcdougall (2009) found that preparation time of the first teaching assignment and mentorship status were areas which posed the greatest difficulties for neophyte teachers.

A case study analysis (Romano \& Gibson, 2006) was conducted for beginning elementary teachers in an attempt to understand the concerns and needs of new teachers entering the profession. In this regard, a total of 29 successes and 29 struggles were identified over the length of the study. The successes and struggles were then grouped into a seven different categories: external policy (administrative routines and procedures), inclusion and special need students, classroom management, personal issues, content and pedagogy, parents and teacher evaluation. It is interesting to note that each particular category had a number of both feelings of: successes and struggles. The largest category of struggles was external policy with 12 struggles, followed in descending order by inclusion and special need students with 7 struggles, personal issues with 4 struggles, and classroom management and teacher evaluation with 2 struggles each. 


\section{School Environment of New Teachers}

Johnson (1990) defined a school workplace conditions as a place where a teacher works, consisting of the following characteristics: (a) physical features such as school buildings and equipment, (b) organizational structures such as collegial relationship between teachers and teacher's workload, (c) sociological features such as teacher's role and status, (d) political features such as teacher's participation to the decision making, (e) cultural features such as teacher's morale, commitment and values, (f) psychological features such as teacher's personality, characteristics and beliefs, and (g) educational features such as curriculum materials and school policies. All of these features of the school workplaces are interdependent and can positively affect a teacher's performance and decision to stay in the teaching field.

School environment appears to play an important role in shaping new teachers' commitment toward teaching. Yee (1990) interviewed and surveyed 59 experienced teachers and found that some of these teachers abandoned the profession because of their adverse and unsupportive workplace conditions. Other teachers stay in teaching because they experience a supportive, cooperative and resourceful school environment. Similarly, Boyd and his colleagues (2011) and Ladd (2011) showed that teachers' stated career intentions, plans and decisions are strongly related to the working conditions.

For new teachers, the decision about whether to remain in teaching is mostly influenced by the school social organization and climate and the types of support that they received from the school. According to Darling-Hammond (1984) and Johnson (1990), a poor school environment can have a major impact on new teachers' initial commitment and willingness to stay in the profession. Poor workplace conditions can make new teachers feel discouraged about their work and are likely to contribute to some of the most talented new teachers leaving the 
profession (Metropolitan Life, 1985; Murphy, Hart \& Walters, 1989). Undoubtedly, supportive school environments provide professional growth opportunities for teachers entering the profession. Supportive school environments are referred to as more responsive workplaces with available and appropriate instructional supplies, adequate workload, teachers' involvement in decision-making, opportunities for professional development in real-time contexts and being mentored by more experienced teachers.

Moreover, Odden and Kelley (1997) and Murnane et al. (1991) showed that competitive salaries and benefits and criteria for awarding salary increases are very important factors to attract and retain the most promising and talented new teachers. New teachers who are not satisfied with their salary tend to leave their job for another career. Weiss (1999) examined the relationship between the first-year teachers' workplace conditions and their morale, career choice commitment and planned retention by extracting data from the databases of School and Staffing Surveys (SASS) in 1987-1988 and 1993-1994. It is important to note that career dissatisfaction and the desire of better salaries and benefits were the main reasons of new teachers abandoning their profession in 1987-988 (Bobitt, Leich, Whitener \& Lynch, 1994). Six years later, the results of a similar survey reported that a sizable proportion of teachers who left their profession enumerated not only the same reasons for leaving but also cited the student discipline problems (Whitener, Gruber, Lynch, Tingos, Perona \& Fondelier, 1997). The author found that a school environment that responds to the needs of first-year teachers might allow them to plan to stay in the teaching field, be committed to teaching as a career choice and be more effective with students. Her findings also revealed that the current system failed to provide supportive induction experiences to new teachers. She supports the hypotheses that first year teachers' morale, commitment to profession and decision to stay in teaching is strongly related to their perceptions 
of workplace conditions such as school leadership and culture, teacher autonomy and discretion, student behavior and social climate.

To examine the effects of school workplace conditions on student achievement growth, teacher satisfaction and career intentions, Johnson and her colleagues (2012) gathered Massachusetts' survey results from three sources: school working conditions, school demographic characteristics and student achievement data. After controlling for student demographics, school and teacher characteristics, the researchers demonstrated that a positive school workplace context contributes to higher rates of student academic growth, increases teachers' job satisfaction and reinforces their initial commitment to stay longer in the teaching profession. Ladd (2011) used data from North Carolina to analyze the relationship between student successes and five school working conditions and found that in addition to school-level student and teacher demographic characteristics, working conditions substantially influenced the school-level value-added scores in mathematics and reading. The quality of a school's leadership and teacher's ratings of school facility were the most important predictors of student achievement in mathematics and reading respectively.

Of the working conditions, the school's culture, leadership of the school's principal and collegial interactions emerged as the most important predictors in teachers' job satisfaction and career plans. Subsequent studies have confirmed that collaboration and interdependent among teachers are key components for teacher's workplace improvement and increased teacher's satisfaction and student achievement. In their study, Louis, Kruse and Marks (1996) concluded that schools performed better when they have strong professional communities in which the innovative practices and pedagogical skills of teachers are developed by exchanging ideas and feedback, sharing goals for student learning and achievement and receiving support of mentor 
teachers in their professional community. Holding formal authority in the school, the principal has a great impact on the school as a workplace for teachers. The principal is the primary leader and educator in a school organizational context. Key responsibilities of the school principal include the following: (a) supervising and evaluating the work of teachers, (b) providing teachers with adequate instructional, curriculum and assessment materials, (c) helping to improve instruction by engaging teachers in induction programs, (d) handling student discipline, (e) maintaining the school facility, (f) building relationships with parents and community members, and $(\mathrm{g})$ hiring new teachers and staff.

Many new teachers, who have fewer less developed skills, heavily rely on principal to provide to them all kind of supports they need for success. School care, position responsibilities and time constraints may not allow the principal to meet the individual need of new teachers. However, a skillful principal can support new teachers by making them work together and collaboratively with their experienced colleagues to accomplish student learning goals. The professional interaction between new and experience teachers must include dialogue on improving teaching, investigation of school curriculum, structured observations and research on pedagogical innovations.

There is also considerable evidence showing that principal plays a fundamental role in school environment by creating positive, collaborative and supportive working conditions for teachers and students( Levine and Lezotte, 1990; Smith \& Andrews, 1990; Quinn 2002) . Not surprisingly, first-year teachers' morale are affected when student misbehavior interferes with their teaching. This can lead to the shrinkage of teacher's productivity and student learning. The worst-case scenario is when first-year teachers become the targets of physical and verbal abuse by students in their workplace. Hence, first-year teachers are more likely to plan to quit their job. 


\section{Curriculum and Assessment Materials}

The curriculum and its associated materials provide teachers with opportunities for developing appropriate skills and knowledge to manage classrooms, design lessons, assess student understanding and teach students well. They are source of guidance for teachers about what to teach and how to teach the instructional materials. Brophy (1982) believed that curriculum materials such as textbooks and teachers' guides offer to teachers a way of improving their instructional strategies for effective teaching.

Ball and Feiman-Nemser (1988) studied 6 new teachers and revealed that teachers who showed resistance to the use of curriculum materials at the early stage of their profession changed their attitude by relying heavily on them over the course of their career due to the lack of other kinds of supports. Kauffman et al. (2002) interviewed fifty first and second year teachers in the state of Massachusetts during the 1999-2000 school year in order to investigate beginning teachers' experiences with curriculum and assessments in the face of state's standards-based assessment. Their findings described the struggle of new teachers to prepare content and materials due to the lack of coherent curriculum and assessment materials. For this reason, Huberman (1989) argued that the relationship between teachers' attitudes and the use of the curriculum materials is related to the teachers 'experience level. Teachers new to the profession faced a major challenge using curriculum materials, but as they are getting more years of teaching experience, they learn how to use curriculum materials to teach effectively.

The interactions between teachers and material resources need to be well conceptualized and clarified in order to help teachers to master the curriculum materials for effective teaching. To investigate the use of science curriculum materials by beginning teachers, Forbes and Davis (2007) studied three new elementary teachers and the relationship between their use of 
curriculum materials and their learning about science and the teaching of science. Their findings indicated that each of these three teachers design their own science curricula by modifying and combining several set of existing science curriculum materials to meet the need of their classrooms. Grossman and Thompson (2004) reported on three new teachers' response to and use of the curriculum materials for their classes. Firstly, they discovered that new teachers spent tremendous amount of time searching and identifying curriculum materials to use in order to teach the most important concepts in an effective way. Secondly, the authors concluded that the curriculum materials provide to new teachers additional learning opportunities by guiding their classroom content organization and enhancing their instructional and assessment strategies. Finally, the authors recommended more opportunities related to the study of curriculum materials for new teachers during their teacher education and curricular conversations between new teachers and more experienced teachers in order to help the new teachers with their jobs . The professional growth of the new teachers related to their use of science curriculum materials was influenced by their conception of effective science teaching and by the characteristics of the singularity of their school settings.

Most of the existing literature have documented that most teachers are considerably dependent on curriculum materials to prepare, plan and teach their lessons (Woodward \& Eliot, 1990; Goodlad, 1985). However, nearly all available current science curriculum materials are of poor quality, fail to improve teachers' professional knowledge and do not provide the appropriate supports for students to meet their well-specified learning goals expectations (Kesidou \& Roseman, 2002; Stern \& Roseman, 2004). As a result, poor quality curriculum materials can diminish the instructional capacity of teachers, particularly new teachers because they do not possess the skills, resources and knowledge necessary to distinguish between strong 
and weak curriculum materials.

Schwarz et al. (2008) and Davis (2006) have advocated for more and better support to new teachers who are struggling in their use of curriculum materials. They believed that learning to use curriculum materials must be a major component of science method courses taught for preservice teachers. Schwarz et al. (2008) analyzed the attitudes of preservice teachers toward curriculum materials after they attended a science methods course containing curriculum analysis and modification based on specified instructional criteria. Their results indicated that preservice teachers accurately applied the structured curriculum analysis material criteria within each method section. Most preservice teachers were able to identify materials and activities that address specific student learning goals because their teachers provided not only an explicit attention to some criteria such as "learning goals", "data into patterns" and "engaging students with phenomena" but also the opportunity for them to use these criteria in different contexts within the course. However, new teachers were struggling to accurately apply the criterion "sense of purpose" because they were not able to determine the goals of a specific activity and its effects on student motivations. Similarly, preservice teachers did not accurately apply and use criterion "application and practice" because they have interpreted the meaning of this criterion as any activity or task providing practical experiences within classroom rather than an activity providing opportunities for students to apply their new knowledge and skills to a new context. These findings show that it is important to help new teachers to develop necessary knowledge and skills to use, analyze and modify curriculum materials by changing the theoretical frameworks and incorporating new methods to get teacher candidates more involve in their use of curriculum materials at earlier stage of their teacher preparation program. 


\section{Science Teacher Education Programs}

Teacher preparation programs are designed to educate, support and equip beginning teachers to meet the expectations of daily classroom life. Darling-Hammond (2006) demonstrated that teachers prepared in powerful teacher preparation programs respond better to the challenges of their first years of teaching compared to others. Liston and his colleagues investigated the role that teacher preparation programs play in preparing beginning teachers. As a result of their discussions with several new teachers, Liston and his colleagues pointed out three reasons for why teacher education programs are doing too little to prepare candidates for the first years of teaching. The first reason is that the teacher preparation programs mostly focused on theoretical knowledge rather than practical skills of teaching which the most important knowledge. In his study, Corcoran (1981) showed that new teachers struggle to transfer their knowledge, acquired from their university coursework, to their students. A different framing argues that new teachers graduate from teacher education schools without learning the right theory. The second reason is that Schools of education do not equip candidates sufficiently for the stress and emotional intensity related to the beginning years of teaching. The third reason is that teacher preparation programs do not provide any type of supports to their recent graduates who land in a less collegial workplaces.

Furthermore, academic preparation plays an important role for teacher candidates because it provides to them with more extensive subject matter knowledge and improves their understanding of the major concepts and topics. A source of beginning teachers' struggles can be related to their lack of adequate academic preparation in terms of coursework in their major teaching area. Many researchers have investigated the difficulty encountered by new teachers in their classroom due to the inadequate preparation for their undergraduate education programs to 
meet the demand of the contemporary classrooms (Flores and Days, 2006; Ulvik, Smith \& Helleve, 2009; Vaughn, Bos \& Schum, 1997). LaTurner (2002) investigated new teachers' academic preparation and found that about $40 \%$ of the respondents in her sample of 211 new teachers had fewer than 18 hours of coursework in their major teaching area. Another study found that prospective elementary school teachers had two college mathematics courses and about $15 \%$ of science and math teachers in middle and high schools in the USA lacked certification and did not have a mathematics or science major in college (National Research Council, 2010). Monk (1994) examined the relationship between the mathematics and science subject area preparation of secondary school teachers and student achievement in these subjects using a panel survey of American middle and high schools science and mathematics education also known as a longitudinal study of American youth data . He used the number of courses taken by a teacher in a subject area as a measure of teacher content preparation. The findings suggest that for the sophomore and junior years, the teacher course preparation in physical sciences such as chemistry, physics and earth science has a statistically significant and positive impact on pupil performance in physical science courses.

In addition, underprepared new teachers may not have the substantive knowledge of the subject they teach, therefore they may not be able to challenge their students' misconceptions. Teacher education programs must directly address prospective science teachers' misconceptions and improve their understanding of science concepts. Shulman (1986) recommended that the knowledge of the most frequent misconceptions and methods to alter these misconceptions to be included in the preparation of science teachers. Indeed, the presence of misconceptions in science can affect the quality of science education programs. Two studies focused on new science teachers' misconceptions. Sheehan (2010) analyzed the pre-service science teachers 
misconceptions on four concept areas in chemistry: particulate nature of matter, mole concept, chemical bonding and equilibrium by giving a pencil-and-paper instrument test to 212 science teacher candidates. The results showed that the percentage of correct answers for the following conceptual areas: particulate nature of matter, mole concept, chemical bonding and equilibrium were $28,43,32$ and 31 respectively. A failure to conserve atoms or understand the role of limiting reagent (75\%) and the confusion of the meaning of coefficients and subscripts (56\%) were the most frequent misconceptions held by pre-service teachers. The number of chemistry misconceptions identified among pre-service science teachers taking part in this study was considerable with more than $80 \%$ scoring less than $40 \%$. This can lead to new science teachers designing a lesson plans which include unscientific conceptions that can interfere with the new and real learning of their students.

Kaltakci and Eryilmaz (2008) investigated the misconceptions of pre-service physics teachers at Middle East Technical University (METU) in Turkey on three topics: "Geometric Optics", "Force and Motion", and "Simple Electric Circuits" using three-tier misconception tests. The results indicated that the average misconception percentages for teacher candidates on the topics of "Geometric Optics", "Force and Motion", and "Simple Electric Circuits" are 12, 11 and 4 respectively. The highest percentage of misconceptions in Geometrics Optics, approximately 73 , was related to the position of an image in the plane mirror. On the topic of Force and Motion, One third of Pre-service science teachers displayed poor understanding about how to identify the largest force that determines the motion of an object. On the final topic of Simple Electric Circuits, the highest percentage of misconceptions was 10 and related to short Circuit. Holding these misconceptions in physics, the new science teachers are likely to transfer them to their students. Teachers, who did not have the appropriate understanding of specific 
science topics and major concepts of science, were not be able to meet the expectations of planning a science lesson, evaluating students' learning and helping students to learn.

\section{Characteristics of Highly Effective Science Teachers}

A growing number of public and private school organizations understand the importance of having an effective science teacher in every classroom because effective teaching lies at the heart of student success. Because of this, many science teaching professionals spend a tremendous amount of time working on becoming more effective teachers. Collins (1990) defines an effective teacher as someone who: (a) is a learning community member, (b) is dedicated to make knowledge accessible to all students, (c) knows enough about the subject matter, and (d) knows how to establish and manage student learning in a positive classroom climate.The general principles of effective science teaching provide a substantial base in the search for teaching excellence in science. After reviewing several teaching models such as 'the learning cycle', 'the conceptual change model', 'the inquiry model', 'the generative learning model', 'the conceptual change model', 'information-processing teaching models' and 'the inquiry model', Cimer (2007) identified six main principles that constitute effective teaching in science based on the theoretical principles of constructivism. The first principle is helping students change their existing unscientific ideas and misconceptions. After identifying the existing ideas, views and conceptions of students, teachers must make them aware of them and use lectures, presentations, textbooks or videos to develop plausible new scientific concepts in order to help students change their non-scientific ideas and construct new knowledge. The second principle is providing opportunities for students, through practical work, writing activities and field trips, to apply their newly acquired knowledge or skills adequately to different real life situations. The third is employing various teaching techniques and strategies such as inquiry- 
based teaching, discussions, questioning and co-operative learning groups to engage students in active learning, involve them in lessons and increase their motivation to learn. The fourth principle is implementing successfully the inquiry-based teaching method in science by developing the skills of students to formulate their own questions and be able to find out answers to the problems. The fifth principle is creating opportunities for students to work and talk with each other aims to clarify their existing ideas about a concept, to correct misconceptions and to create connections among concepts. The sixth principle is evaluating continuously the thinking and understanding of students and provide them with detailed positive feedback on their performance and work in order to increase student participation in the self-assessment process of their learning. Teachers were expecting to make a positive difference in the lives of their students by applying the principles of effective science teaching.

Beginning teachers views of effective science teaching influence and translate into their classroom science instruction. Davis (2008) studied longitudinally six beginning elementary teachers over three or more years of practice and identified five conceptions of effective science teaching. The first conception about effective science teaching is largely gauged in terms of long-term curricular plans development with an emphasis on the outcomes expectancy of the instruction such as the ability to help students to achieve learning goals. The second conception focuses on the ability to improve student's conceptual understanding of science through inquiry practices, hands- on experiences and classroom activities. The third conception about effective science teaching places emphasis on the use of explanations, evidences and claims based on scientific investigation to answer to scientifically oriented questions. The fourth one values a combination of the use of conceptual understanding of science through textbooks with the use of experimentation. The final conception about effective science teaching highly prioritizes the 
development of students' general skills to be valuable citizen and successful science learner. The expression general skills refers to the students' ability or proficiency to seek out information in books, work in group, read non-fiction, take notes and be successful test-takers. Moreover, Gezer and Bilen (2007) investigated the views of preservice science teachers about the characteristics of effective science teaching and effective science teacher by analyzing teachers' answers to open ended questions using document's and content analysis techniques. The answers of the preservice teachers about the properties of effective science teaching and effective science teacher was classified in five groups: (a) structure of science, (b) methods of teaching, (c) occupational properties, (d) personal properties, and (e) classroom atmosphere.

The researchers discovered that teacher candidates highlighted some essential qualities of effective science teachers as follows: being patient, having subject matter knowledge, encouraging students to ask questions and reaching the student's level. The most important properties of effective science teaching preferred by preservice teacher are the use of laboratory method and techniques to make connection between current events and science topics. In other words, it is necessary for science teachers to integrate projects, activities and experiments in their science lesson plans and to gain students participation in the course. Fajet, Bello, Leftwich, Mesler and Shaver (2005) used questionnaires, surveys and interviews to examine beginning teachers' perceptions about teaching, and in so doing, identify and determine the qualities and characteristics of both good and poor teachers. Five themes emerged from the data, capturing beliefs and perceptions relevant to identify determining characteristics of a good and bad teacher. The five themes were: (a) pedagogy/classroom management - Preservice teachers believed that good teachers utilize multiple methods of instructions to make student learning interesting and maintain control of their classrooms, (b) affective: personal 
characteristics - Good teachers are believed to have a good relationship with their students, (c) attitudes and behaviors toward students - Good teachers are expected to exhibit positive personal characteristics such as being passionate, energetic and enthusiastic and to transfer these attitudes and behaviors to their students, (d) attitude toward job/teaching in general - Preservice teachers believed that good teachers are well-organized, work hard and show commitment to teaching, and (e) knowledge of subject matter- Preservice teachers noted that good teachers must know about and have interest in the subject they are teaching.

In Moreira's study (2002), several high school students were asked to write an essay about the properties of an effective teacher and the following characteristics were underlined: (a) explains how to do assignments by giving examples and some additional materials to students, (b) teachers' personal problems do not interfere in their relationship with students, (c) grades based only on mastery of instructional materials, (d) is sincere and kind, (e) enforces the classroom and school rules consistently, (f) cares about students and their education, (g) respects students; does not allow humiliations and sarcasm in the classrooms, and (h) makes learning process fun, interesting and enjoyable for students.

Based on the findings from many studies examining the perceptions of new teachers about the characteristics of competent teachers, the qualities of an effective teacher fell into two categories: professional competencies and affective qualities ( Artiles \& Trent, 1997; Minor, Onwuegbuzie \& Witcher, 2000; Segall \& Wilson, 1998; Weinstein, 1990). Professional competencies include the ability to transfer the content area knowledge to students, develop student creativity, gain students interest and use experiments and hands-on-activity to engage students. Effective teachers are further able to treat all students in their classroom fairly, use different teaching methodologies to meet student learning objectives, well-organize classroom by 
planning the lessons ahead and use different techniques to establish and maintain order in the classroom. The ability to establish a strong and healthy relationship with students, understanding of student needs, intellectual potential and interest, being easy to meet or deal with, fairness, honesty, patience, supportiveness and caring are considered affective qualities of effective teachers. Another important affective quality of effective teachers is their ability to use studentcentered teaching methods by shifting the focus of classroom activity from the teacher to the students. According to Weinstein (1989), teacher affective qualities is seen by new teachers as the most important category of qualities and characteristics of effective teachers.

\section{Beliefs about Science}

It is important to note that there is a strong correlation between teachers' beliefs and classroom practices, and thus any techniques applied to professionally develop teachers must take into account both concepts (beliefs and practices) simultaneously (Stipek, Givvin, Salmon \& MacGyvers, 2001). According to Pajares (1992), belief is the individual's ability to determine the correctness or falsehood of a statement or premise. The term beliefs also refers to the ability to form an opinion based on a community perception and interpretation of people claims, actions and intentions. Teacher's belief is defined as teacher's opinion, view, assumption or conviction about the teaching and learning process.

Several studies have reported that the preservice teachers' beliefs and perceptions about science content and teaching are combined with feelings of anxiety, professional incompetent and hesitancy (Carter, Sottile \& Murphy, 2002; Cheng, 2002; Tosun, 2000). When starting teaching in their own classroom, the majority of the preservice teachers doubt their ability to convey the knowledge to their students and to explain the scientific concepts in an easy, simple and fun ways to their students. Yesil-Dagli, Lake and Jones (2005) analyzed the beliefs of early 
childhood preservice teachers about mathematics and science using a qualitative approach and found that preservice teachers experience of mathematics and science during their college years greatly influence their beliefs and perceptions about mathematics and science.

Preservice teachers, who did not like mathematics and science, while they were in school, did not feel confident about their professional competencies to teach mathematics and science. Furthermore, students' learning and perceptions towards science were shaped by the beliefs of their teachers related to science. Good and effective science teachers can simplify science concepts and make science lessons meaningful, interesting and fun for their students, thus increasing student ability to understand and master science concepts.

In her study, Kanga (1992) grouped teachers' beliefs into two categories: teaching selfefficacy and content-specific beliefs. Implicit assumptions about how to be effective teachers and improve students' achievements are considered self-efficacy beliefs. Research indicates that positive teaching behavior and desired outcomes of student engagement and learning are shaped by the concept of teacher efficacy (Gibson \& Dembo, 1984; Henson, 2001; Woolfolk \& Hoy, 1990). Content-specific beliefs refer to the beliefs that teachers have in their learning and knowledge ability about their teaching fields.

In an attempt to investigate the science teaching beliefs held by teachers, many researchers refer to the Alfred Bandura's social cognitive theory of personality. Self-efficacy, a major concept of the theory of Alfred Bandura (1977), is defined as beliefs about somebody's ability to achieve goals and resolutions by performing specific task. Bandura (1997) claimed that teachers with high self-efficacy are those who believe that they can be effective teachers and perceive their career- related challenges as sources of motivations resulting in a good task planning to reach their goals rather than sources of discouragement and giving up. Furthermore, 
teachers with a strong sense of efficacy tend to exhibit greater levels of persistence and resilience when facing challenges, have strong planning and organizational skills (Allinder, 1994), are very enthusiastic and passionate about teaching (Guskey, 1981), are fully committed to the teaching profession (Coladarci, 1992) and are planning to stay longer in the field (Burley, Hall, Villeme \& Brockmeier, 1991).

The preservice science teacher efficacy is influenced by four factors: (a) science enactive mastery science involving hands- on activities related to science undertaken by teachers, (b) observational learning is when new teachers observe their professors and more experienced colleagues teaching a classroom in order to explore the use of different teaching strategies and procedures, (c) verbal persuasion which refers to teachers receiving verbal feedback such as encouraging, uplifting and inspirational words, and (d) physiological and affective factors results in teachers creating a positive learning atmosphere and successfully completing classroom activities. Gencer and Cakiroglu (2005) measured the efficacy beliefs of Turkish preservice science teachers about teaching science and classroom management using the Science Teaching Efficacy Belief Instrument (STEBI) form B and the Attitudes and Beliefs on Classroom Control $(\mathrm{ABCC})$ inventory. They found that most of the preservice science teachers have greater confidence in their ability to teach science effectively. To be effective teachers, the preservice science teachers believe that they should control their students' instructional activities and maintain order in their classroom. Preservice science teachers also believe that students, who are taught by effective science teachers, can learn science faster and better. In addition, preservice science teachers tend to favor non-interventionist style on the people management dimension of the ABCC inventory which includes the teacher-student relationships. Cakiroglu, J., Cakiroglu, E., and Boone (2005) compared the self-efficacy of future science teachers in two countries: 
Turkey and USA. They concluded that preservice teachers in USA had significantly higher beliefs on themselves for helping students to better understand scientific concepts. However, preservice teachers in Turkey had stronger beliefs in themselves to be able to answer students' science questions. According to Bandura (1986), the sense of the concept of teacher efficacy varies across not only the type of teacher duties and responsibilities but also the subject matter. In addition, the concept of teacher efficacy is not uniform across the many different features of cultures.

According to the United Nations Development Programme and Kingdom of Saudi Arabia (2003), the elementary science curricula and textbook of most of the countries in the Middle East, including the Kingdom of Saudi Arabia, were based on teacher-centered techniques and on memorization of content knowledge. To address this issue, the Kingdom of Saudi Arabia Ministry of Education introduced new elementary science curricula that place heavy emphasis on problem-solving and critical-thinking techniques in the process of teaching and learning science. Indeed, science education researchers have recommended to science teachers to instruct students not only basic scientific information, laboratory and experimental procedure skills but also knowledge through observation, comparison and application of scientific thinking skills in order to prepare students to be scientifically literate.

Alghamdi and Al-Salouli (2012) investigated Saudi science teachers' beliefs about the process of teaching and learning science within the context of new science curricula by interviewing ten science teachers with diverse academic backgrounds and varied teaching experiences. They found that the common major beliefs of science teachers in the Kingdom of Saudi Arabia schools can be grouped into five themes: (a) the existing beliefs of science teachers about teaching science were employed to suit the implementation of the new science curricula 
goals and teaching approaches, (b) there was a poor coordination between the current textbooks and the new science curricula learning objectives due to the large number of topics in the textbooks and a limited class time to cover the materials, (c) The understanding of the new science curricula and the use of new teaching techniques were delayed by several internal barriers such as instructional time, student diversity, class size, lack of laboratory space and equipment, (d) There is a lack of professional learning and development opportunities for novice teaches, and (e) science teachers experienced major joys and success when implementing the new curricular because they provide the opportunities for students to think, argue and discuss scientific concepts rather than reading about them. 


\section{Chapter 3: Study Design and Methodology}

\section{Introduction}

To investigate the challenges that newly hired science teachers encounter in their profession, a combined quantitative and qualitative research design was used. Sieber (1973) claimed that quantitative and qualitative methods have distinctive strengths and weaknesses and advocated for the integration and use of the strengths of both methods within a single study to have a more comprehensive understanding of research problems and complex real-world phenomena. In addition, Lincoln and Guba (1985) assert that quantitative and qualitative research methods employ different established methods to meet the research quality expectations but both research methods highlight truth, neutrality, applicability and consistency. Moreover, the combination of quantitative and qualitative research methods is becoming an increasingly popular approach that is constantly being displayed through studies in journal articles, conference proceedings and books because it provides a better evaluation of research findings and increases the validity of findings by analyzing the same research problems from multiple perspectives. The following terms were used to describe the benefits of combination of quantitative and qualitative research approach to data collection: integrative research (Johnson and Onwuegbuzie, 2004), blended research (Thomas, 2003), third methodological movement (Tashakkori \& Teddlie, 2003), new star in the social science sky (Mayring, 2007) and mixedmethods research (Johnson \& Christen, 2004). The mixed-method research design often contains the elements of quantitative and qualitative research approaches that are used and combined in many and diverse ways within different phases of the study.

Quantitative research is usually described as the class of investigation where the researcher employs empirical methods for the purpose of explaining research questions of 
interest. In addition, according to Creswell (1994), quantitative research refers to the collection and analysis of numerical data via mathematically based methods in order to describe, explain and predict phenomena. The objectives of quantitative research methods are to minimize the influence of the researcher's beliefs on the research findings and to maximize objectivity and generalizability of findings at the same time. The advantages of quantitative research methods are that the researcher can summarize large information with greater accuracy and less time consuming, test hypotheses, eliminate bias, establish cause-and-effect relationships and generalize research findings.

Quantitative research methods can be categorized as survey research, correlational research, experimental research and casual-comparative research. A key feature of the quantitative research design is the use of survey research. Survey research refers to a group of descriptive research methods that collect and compile information about the attributes, behavior, attitudes and needs of a population. As noted by Groves and his colleagues (2004), survey provides a quantitative description of the characteristics of a population by gathering information from a representative portion of this population. The advantages, strengths and benefits of the survey method of research are that it is inexpensive, quickly created, easily administered, replicable and large amount of data can be obtained in a relatively short period of time. In this study, the survey was used to assess the population of new science teachers' characteristics, personality and beliefs. The variables related to the new science teacher population characteristics used in this study are age, gender, marital status, the number of years of teaching experience, types of degrees (bachelor or master), types of administrator, level (elementary, middle and high school) and the discipline (history, math, science, and so on) they are teaching. Moreover, the quantitative survey method was used to assess the new science teacher's 
challenges, needs and the support they received.

To investigate the new teachers' perception of effective teaching and teacher support, qualitative research methods were used. Qualitative research is a method of investigation and an inquiry process of understanding of social and cultural phenomena. It is often referred to by a variety of data collection techniques such as observations, videotapes, field notes, interviews, reflexive journals, case studies, materials and documents. Nkwi, Nyamongo and Ryan (2001) describe qualitative research design as a research that involves text, images or sounds. As a consequence, qualitative research can be associated with many different kinds of theoretical and epistemological frameworks as well as the incorporation of the diversity of gathering information methods. The strengths of qualitative approach include the flexibility in study design, in-depth analysis and the opportunity to observe many different aspects of a research problem.

In this study, qualitative research design allowed the researcher to discover and understand the complex reality of new science teachers in the Kingdom of Saudi Arabia by employing the interview method and content analysis of responses. Interviews enabled the researcher to get to know better the individual thoughts, feelings, beliefs and concerns of beginning science teachers in Saudi Arabia. Interviews are methods by which the researcher gathers data and gain knowledge from study participants through conversations. According to Kvale (1996), interviews are a meeting between two or more people to exchange information, ideas and perceptions on a topic of mutual interest in order to explain or clarify a point of view. Interviews have the advantages of providing a higher level of detailed description from the interviewee, increasing useful cognitive and affective response rates from the interviewee by clarifying questions, and gaining new insights of interviewees' experiences. 
Content analysis is a research method of collecting and organizing information from different sources such as organization, agency, clinical or program records; personal diaries; official publications and reports; memoranda and correspondence; and open-ended written answers to surveys and questionnaires. Bryman (2004) defined qualitative document analysis as an approach to analyzing documents that highlights the researcher's role, the emergence of the underlying themes out of data and the importance of understanding the meaning of the study context. In addition to the approach to document method, qualitative document analysis tends to include simultaneously a more valuable and explicitly approach to document analysis using a category system (Mayring, 2000). Content analysis can be used to describe, summarize, study and analyze the content of written materials and documents, the views of its authors and the impact on its readers.

\section{Population and Sampling}

The population of this study was all first, second and third year science teachers working in a wide range of traditional public, charter, and private schools located in urban and rural areas of Al Jouf, a province of the Kingdom of Saudi Arabia. It is important to note that the study population also represented a range of all three levels of education: elementary, middle, and high schools and individuals who teach different science disciplines such as life science, physical science, earth science and general science.

\section{Survey Participants}

A survey questionnaire was constructed and distributed in-person to new science teachers who currently work in the schools of the province of Al Jouf. Each participant was asked to complete and return the survey. The participants were also asked to answer several open-ended questions in the survey by formulating answers in their own words. The research 
sample consisted of elementary, middle and high school teachers with 0-3 years of teaching experience who teach different science subjects. For this study, a total of 120 new science teachers were invited to take the surveys, of whom 49 participated in the surveys. The response rate of the surveys was about $41 \%$. The demographic characteristics of the study sample are presented in Table 1. Figure 2 also presents a frequency distribution of each demographic group. The sample was stratified by teaching experience, school level and gender. The vast majority of the participants were made up by teachers with experience of 3-4 years with 32 participants. Coming in a distant, second and third were teachers with experience of 2-3 years and teachers with experience of 1-2 year with 8 and 9 participants respectively. The variable school level included 26 new science high school teachers, 17 middle school teachers and 6 elementary school teachers. Fifty-six percent of the participants were men.

Table 1: Sample Demographics

\begin{tabular}{|lr|lc|lr|}
\hline \multicolumn{2}{|c|}{ Teaching Experience } & \multicolumn{2}{|c|}{ School level } & \multicolumn{2}{c|}{ Gender } \\
$1-2$ years & 8 & Elementary school & 6 & Male & 28 \\
$2-3$ years & 9 & Middle school & 17 & Female & 21 \\
$3-4$ years & 32 & High school & 26 & & \\
\hline
\end{tabular}




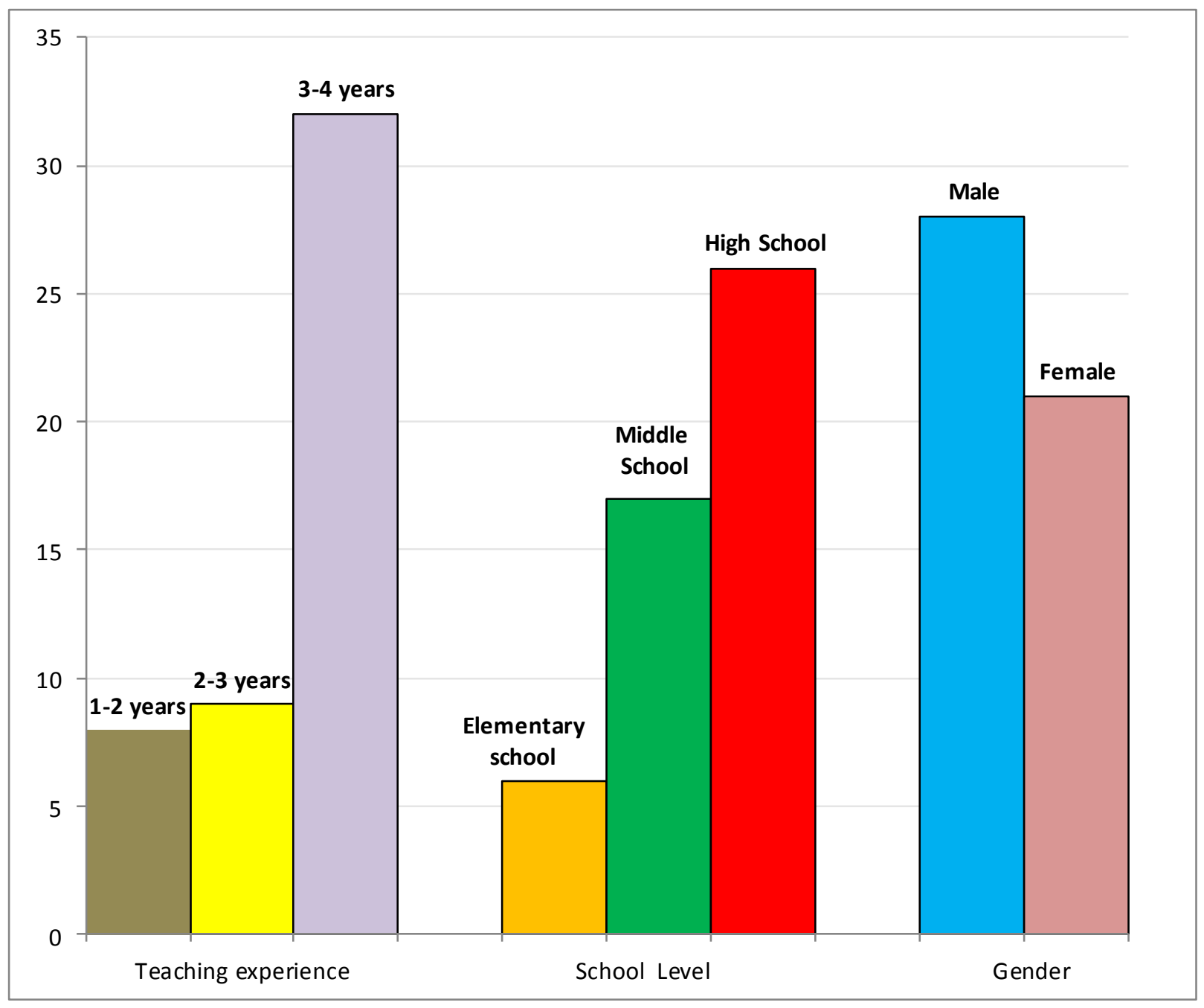

Figure 2: Demographic Frequencies

\section{Interview Participants}

The survey was then linked to a face- to- face interview to provide greater detail and depth. All the survey respondents were asked to participate in the face- to- face interview. Only nine new science teachers agreed to participate voluntarily in the face -to- face interview from the pool of 49 new science teachers. Table 2 provides demographic information for the nine novice science teachers who took part in the semi-structured interviews. This information contains the pseudonyms of the participants, gender, science subject, school level, teaching experience, number of classes and the size of the classrooms they teach. 
Table 2: Summary of characteristics of the interview participants

\begin{tabular}{|l|l|l|l|l|l|l|}
\hline $\begin{array}{l}\text { Participant } \\
\text { Name } \\
\text { (Pseudonyms) }\end{array}$ & Gender & $\begin{array}{l}\text { Science } \\
\text { Subject } \\
\text { Area }\end{array}$ & $\begin{array}{l}\text { School } \\
\text { Level }\end{array}$ & $\begin{array}{l}\text { Teaching } \\
\text { Experience }\end{array}$ & $\begin{array}{l}\text { Number of } \\
\text { classes } \\
\text { Taught }\end{array}$ & class size \\
\hline Maryam & Female & Biology & $\begin{array}{l}\text { Middle } \\
\text { School }\end{array}$ & between 3-4 years & 3 & $\begin{array}{l}31-35 \\
\text { students }\end{array}$ \\
\hline Leila & Female & Chemistry & $\begin{array}{l}\text { High } \\
\text { School }\end{array}$ & between 3-4 years & 4 & $\begin{array}{l}30-39 \\
\text { students }\end{array}$ \\
\hline Fatimah & Female & $\begin{array}{l}\text { Earth } \\
\text { Science }\end{array}$ & $\begin{array}{l}\text { High } \\
\text { School }\end{array}$ & between 3-4 years & 3 & $\begin{array}{l}20-29 \\
\text { students }\end{array}$ \\
\hline Ali & Male & Chemistry & $\begin{array}{l}\text { High } \\
\text { School }\end{array}$ & between 3-4 years & 3 & $\begin{array}{l}20-29 \\
\text { students }\end{array}$ \\
\hline Kareem & Male & $\begin{array}{l}\text { Earth } \\
\text { Science }\end{array}$ & $\begin{array}{l}\text { Middle } \\
\text { School }\end{array}$ & between 1-2 years & 3 & $\begin{array}{l}30-39 \\
\text { students }\end{array}$ \\
\hline Abdullah & Male & $\begin{array}{l}\text { General } \\
\text { Science }\end{array}$ & $\begin{array}{l}\text { Elementary } \\
\text { School }\end{array}$ & between 2-3 years & 2 & $\begin{array}{l}30-39 \\
\text { students }\end{array}$ \\
\hline Omar & Male & $\begin{array}{l}\text { General } \\
\text { Science }\end{array}$ & $\begin{array}{l}\text { Elementary } \\
\text { School }\end{array}$ & between 1-2 years & 2 & $\begin{array}{l}20-29 \\
\text { students }\end{array}$ \\
\hline Ibrahim & Male & $\begin{array}{l}\text { Physics } \\
\text { Shigh } \\
\text { School }\end{array}$ & between 3-4 years & 2 & $\begin{array}{l}20-29 \\
\text { students }\end{array}$ \\
\hline Khalid & Male & $\begin{array}{l}\text { Earth } \\
\text { Science }\end{array}$ & $\begin{array}{l}\text { High } \\
\text { School }\end{array}$ & between 2-3 years & 3 & $\begin{array}{l}40-49 \\
\text { students }\end{array}$ \\
\hline
\end{tabular}

\section{Procedure and Instrumentation}

After approval of the study was received by the West Virginia University Institutional Review Board for the Protection of Human Subjects (IRB), the researcher gained permission from the school principals to conduct the survey and to interview the new science teachers at their current and respective schools (see appendix A). A meeting was scheduled at a given school with the new science teachers of that school to discuss the research objectives and to inform them about privacy and confidentiality policies used for the study. At the school meeting, all participants were given a consent statement that emphasized and clarified the purpose of the study, the confidentiality of the study, the risk and benefits for the participants.

After receiving approval from some new science teachers to participate in the study, the researcher gave them the surveys. For those new science teachers who were not able to attend the 
meeting, the researcher met with them at their earliest convenience to discuss the objectives of the study.

In the survey research design, the researcher asked the new science teachers to fill out a questionnaire on their own. The names of the participants were not attached to the surveys to maintain anonymity and confidentiality of the participants. The researcher assigned a unique serial number to the returned survey questionnaire before entering the data into the computer.

The survey was followed by a face-to-face interview with participants who were willing to be interviewed. Each participant was contacted by the researcher to request their participation in the interview (see Appendix E). The participants were allowed to select the place and time for their interviews.

A variety of techniques were used to collect data. These techniques were divided into two categories: quantitative and qualitative methodologies. In the literature, many researchers across different disciplines have recommended the use of multiple methods to investigate complex research problems (Creswell, 2003; Newman \& Benz, 1998; Mingers, 2001). In addition, Brannen (2005) firmly believed that there is a compatibility and complementarity between the qualitative and quantitative methods.

The quantitative research design instrument consisted of three survey questionnaires. These surveys were used to answer the first research question related to the challenges faced by science teachers in their first three years of teaching.

The first survey questionnaire gathered information on the demographics of the study sample (see appendix B). It consisted of 14 questions and included the following demographic information: gender, marital status, age, school level, education degree, teaching experience, teaching specialty and professional satisfaction. 
The second survey questionnaire sought information on the level of academic challenges faced by new science teachers in the Kingdom of Saudi Arabia using a series of 25 teaching challenges (see appendix C). It was adopted from the studies conducted by Veenman (1984) and Evans and Tribble (1986) with slight modifications for the purposes of this study. In Evans and Tribble's study, the Cronbach Alpha showed the reliability for the teaching challenges was 0.75 which was appropriate for this study. New science teachers were asked to rate on a scale the challenges that they encountered in their profession. A 5-point Likert scale was used to measure the level of each teaching challenges. The levels of challenges faced by new science teachers were indicated as "major challenge" (1), "challenge" (2), "moderate challenge" (3), "minor challenge" (4) and "no challenge" (5).

A significant body of research has reported that beginning teachers generally expressed greater concern about classroom behavior problems (Corcoran, 1981; Fuller, 1969; Gold, 1996; Reeves \& Kazelkis, 1985; Veenman, 1984). For this reason, the third survey questionnaire aimed to identify the level of the behavioral challenges faced by new science teachers in Saudi Arabia (see appendix D). The questionnaire contained 20 questions adapted from Al-Amarat's study (2011) with scale and question modifications. In his study, Al-Amarat used the Cronbach alpha of 0.93 for behavioral challenges which fit in perfectly with the present study. The frequencies of problem identification were used to determine the level of the challenge and measured according to a 5-point Likert scale item format: great deal (1), moderate amount (2), occasionally (3), rarely (4) and never (5).

Data collection also involved semi-structured interviews (see appendix F) in which participants presented their education background, teaching career, teaching beliefs, working environments and their experience with curriculum and assessment materials. The semi-structure 
interview was organized by the last major research question. The interview questions were related to research question three which focused on effective teaching and teacher support.

The interviews focused explicitly on major challenges the new science teachers encountered in their career, beliefs and perceptions of effective science teaching and supports they received from their schools. A narrative summary for each participant was written. All interviews were voice-recorded and fully transcribed.

\section{Statistics}

The results of the surveys were tabulated and formatted into a spreadsheet for analysis using SPSS software. It is important to note that there were a number of different statistical methods used to analyze the results of the surveys. The results of the demographic survey were analyzed using descriptive and summary statistics because they provide valuable information about the properties and attributes of the new science teachers in the Kingdom of Saudi Arabia. Frequency statistics were calculated for the variables of study: gender, school level and teaching experience.

There were three major steps taken to analyze the results of the survey questionnaires related to the academic challenges faced by new science teachers. First, each participant's scores on each of the 25 challenges were added together to give a total challenge score. Second, the mean estimates of the challenges were computed leading to a serial rank order of the 25 teaching problems. Third, the Mann-Whitney test and the Kruskal-Wallis non-parametric analyses of variance for academic challenge rankings were used to determine if there were significant differences between the variables of the study. The non-parametric statistics methods were used for studying the ranking order of academic challenges faced by new science teachers. The outcomes of academic challenges faced by new science teachers were ordinal and ranked 
data and did not follow a normal distribution.

Means and standard deviations of the frequency of times a behavioral challenge encountered in the classroom by new science teachers were computed in order to analyze the results of the survey related to the classroom behavioral challenge. The researcher primarily relied on the mean values to assess the level of behavioral challenges faced by new science teachers. A higher level of behavioral challenge was characterized by lower means value whereas a lower level of behavioral challenge was characterized by higher means. Subsequently, an independent samples t-test was performed to compare whether the male and female new science teachers encountered the same or different classroom behavioral challenges. The analyses of variance (ANOVA) was also used to determine whether there were any significant differences in the behavioral challenges encountered by new science teachers in their classrooms among first- year, second- year and third- year new science teachers and among high school, middle school and elementary school new science teachers. The parametric tests (Ttest and ANOVA ) were used to determine the frequencies of behavioral challenges faced by new science teachers in their classrooms. The outcomes of the frequencies of behavioral challenges are continuous data and can be better analyzed using parametric tests.

From the results of the independent samples t-test and ANOVA, the main effects of new teacher teaching experience, school level and gender separately across the challenge levels of classroom management were analyzed as shown in Figure 3. 


\section{School level}

1. Elementary

2. Middle school

3. High school
Teaching experience

1. 0-1 year

2.1-2 years

3. 2-3 years

\section{Gender}

1. Male

2.Female

\section{Challenges}

1.Major challenge

2.Challenge

3.Moderate challenge

4. Minor challenge

5.No challenge

Figure 3: Effects of Independent variables on the dependent variable

For this study, it was also important to determine the effects of combined factors of new science teacher experience, school level and gender on the dependent variable classroom management challenges. Figure 4 illustrates the interactional effects of the factors (teaching experience, school level and gender) on the classroom management challenges. 

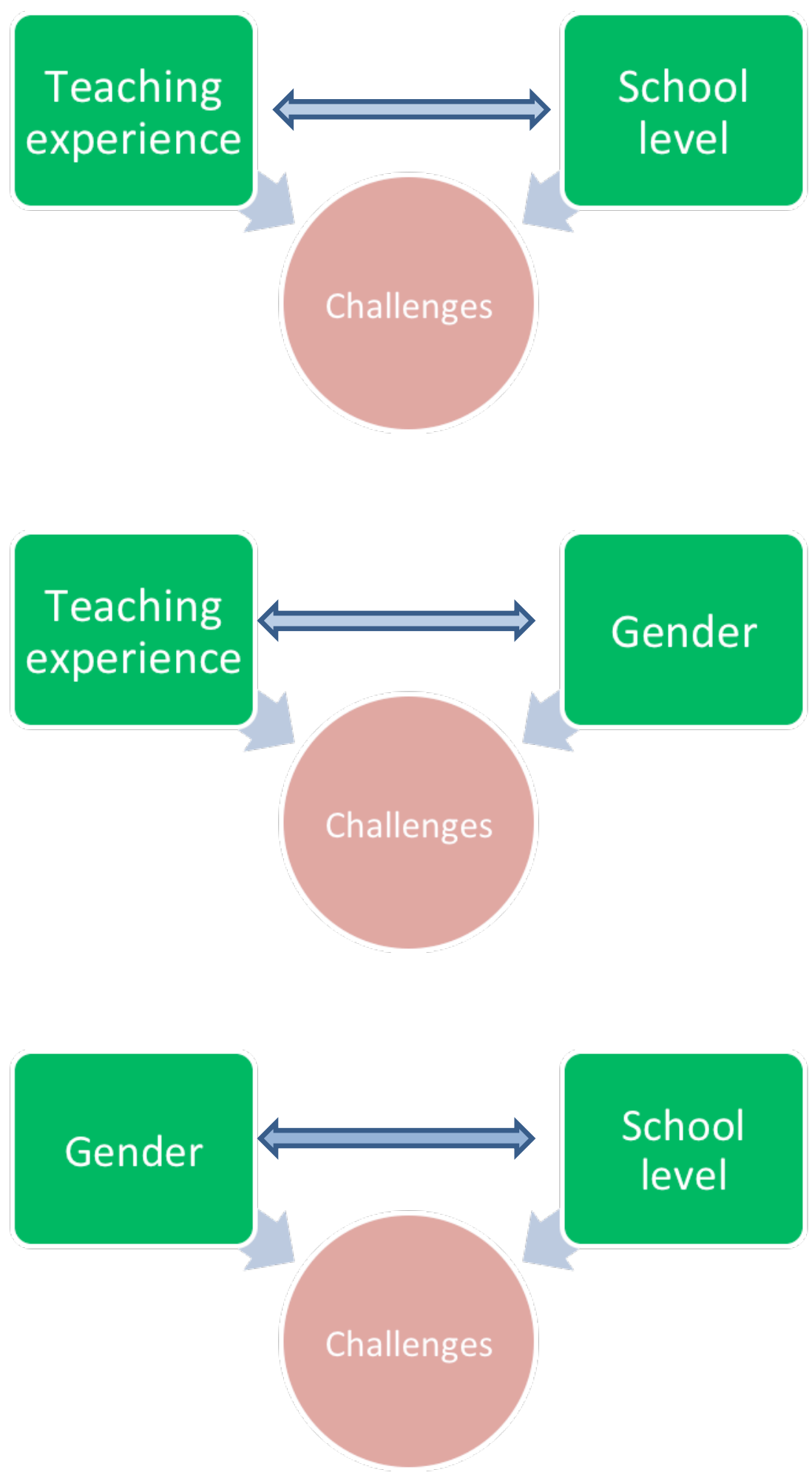

Figure 4: Interactions of Independent variables on the dependent variable 
In this study, open-ended written responses to questionnaires and surveys of new teachers who are involved in science teaching were analyzed, in addition to interviews by employing a multistage coding scheme. In analyzing the narrative summary of each participant, beginning science teachers' relevant ideas, feelings and emotions concerning the problems encountered in their profession were identified and outlined. Then, notable arguments and prominent topics were sorted into categories for discovering patterns in the data. The broad categories of emergent themes were built gradually and purposively by putting together a series of analytic matrices, writing analytic memos and sustaining productive discussions. Once the data were classified according to the principal field of study, they were sorted into a secondary field of study based on the themes identified in the narrative summaries. The aim of this technique was to provide a closer look at the data and develop a deeper appreciation of the content.

\section{Summary}

The whole chapter three is summarized in Figure 5 using a graphic diagram. The chapter described the research design, methods, strategies and participants used in this study to achieve the research objectives. Data collection and analysis processes were also covered in this chapter. 


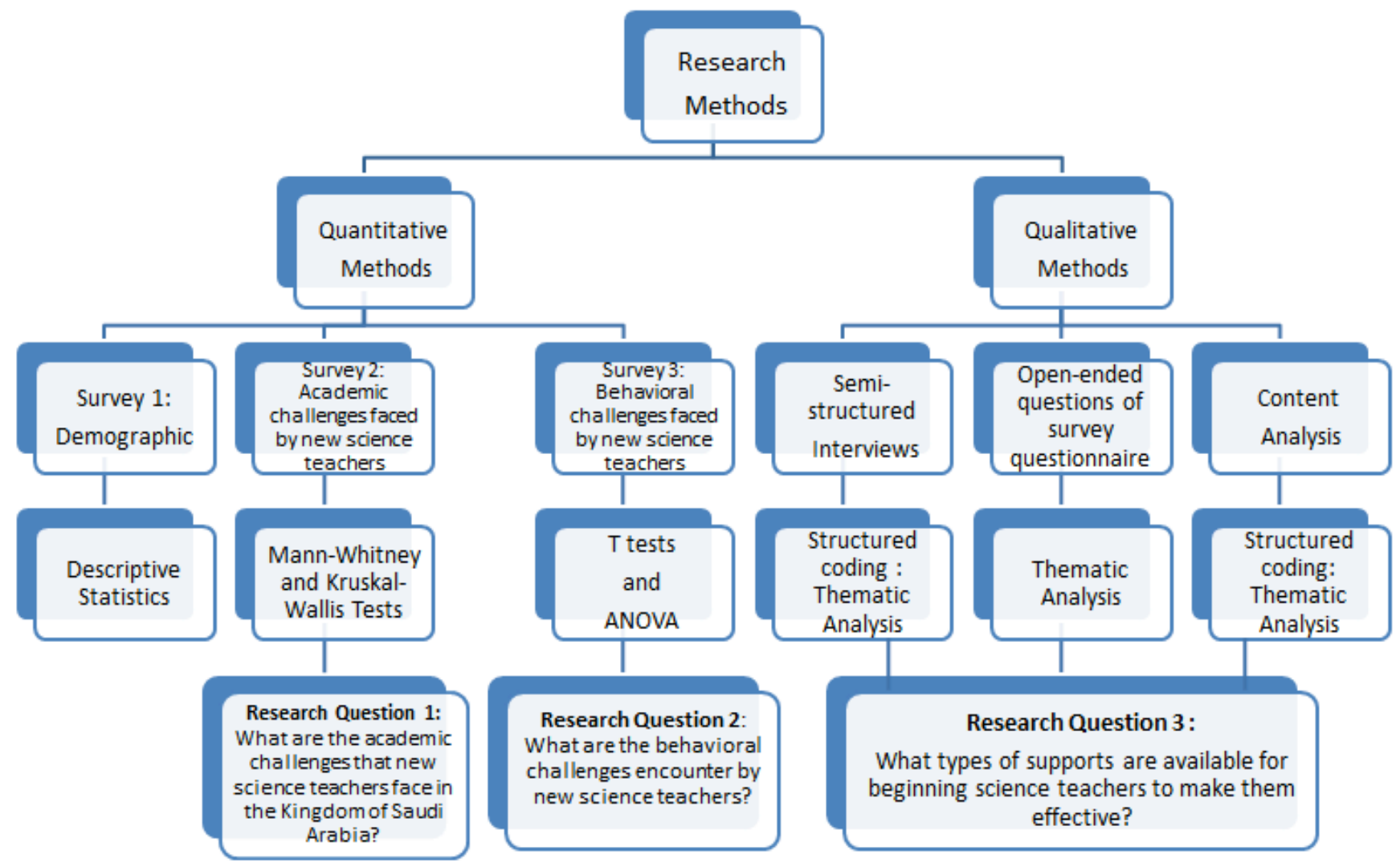

Figure 5: Summary of Research Design and Methodology 


\section{Chapter 4: Findings and Discussions}

\section{Introduction}

The main purpose of the study was to investigate the challenges encountered by beginning science teachers in their profession in Saudi Arabia. The reporting of results and discussion were categorized by the research questions of the study. Therefore, the results and discussion of this study were divided into three sections.

The first section examines and reviews the results of the second survey questionnaire, the survey related to academic challenges faced by new science teacher (Appendix C), to answer the first research question: What are the academic challenges that new science teachers face in the Kingdom of Saudi Arabia?

The second section includes the results and discussions of the third survey instrument with a set of questions related to the behavioral classroom challenges (Appendix D) in the attempt to answer the second research question: What are the behavioral challenges encountered by new science teachers in their classrooms?

The third section analyzes and discusses the results of the semi-structure interviews with several new science teachers (Appendix F) to investigate the third research question: What types of supports are available for beginning science teachers to make them effective?

\section{Research Question 1 - Academic Challenges}

The first research question sought to identify the academic challenges faced by science teachers in their first three years of teaching. To achieve this goal, the total scores of academic challenges faced by new science teachers were calculated by adding the score of each participant on each of the 25 listed challenges. The total scores were then ranked from the lowest score value to the highest value of the science teaching challenges. Lower score values imply a higher 
level of concern about a given challenge, whereas higher scores indicate a lower level of science teaching challenges. The total scores and rankings of science teaching challenges faced by novice science teachers are presented in Table 3. As can be seen, total scores of academic challenges ranges from 103 to 164 . These results revealed that the three most important challenges faced by the new science teachers who took the surveys were: teacher preparation program $($ score $=103)$, school equipment and facility (score $=104)$ and materials and supplies $($ score $=111)$.

Table 3: Total scores and rankings of academic challenges faced by new science teachers

\begin{tabular}{|r|l|r|r|}
\hline $\mathbf{N}$ & Challenges & Score & Rank \\
\hline 1 & Teacher preparation program & 103 & 1 \\
\hline 13 & School equipment and facility & 104 & 2 \\
\hline 14 & Materials and supplies & 111 & 3 \\
\hline 12 & Salary and benefits & 121 & 4 \\
\hline 7 & Determining learning level of students & 122 & 5 \\
\hline 6 & Heavy teaching load & 124 & 6 \\
\hline 3 & Effective use of different teaching methods & 127 & 7 \\
\hline 2 & Knowledge of science subject matter & 129 & 8 \\
\hline 9 & Dealing with challenges of individual students & 135 & 10 \\
\hline 11 & Motivating students & 135 & 10 \\
\hline 21 & Opportunity for professional growth & 135 & 10 \\
\hline 20 & Opportunity to influence over school decision making & 142 & 12 \\
\hline 10 & Classroom discipline & 146 & 13 \\
\hline 5 & Organization of class work & 148 & 14 \\
\hline 19 & Burden of administrative/clerical work & 151 & 15.5 \\
\hline 24 & Being accepted by students & 151 & 15.5 \\
\hline 23 & Teacher job satisfaction & 152 & 17 \\
\hline 18 & Awareness of school policies, rules and procedures & 153 & 18.5 \\
\hline 22 & Community recognition as a professional & 153 & 18.5 \\
\hline 4 & Planning lessons and school days & 154 & 20 \\
\hline 8 & Assessing students' work & 156 & 21.5 \\
\hline 17 & Relations with student's parents & 156 & 21.5 \\
\hline 16 & Relations with administrators & 157 & 23 \\
\hline 25 & Understand teacher performance evaluation system & 164 & 24 \\
\hline 15 & Relations with colleagues & 175 & 25 \\
\hline & & & \\
\hline
\end{tabular}


The most fundamental challenge faced by new science teachers involved in the study was their low level of preparation with regard to science topics. The majority of these new science teachers felt that they were not prepared to deliver science related subjects instruction effectively. This situation arises because the government of Saudi Arabia has failed to establish a clear policy on teachers' licensure. In Saudi Arabia, science teachers are not required to obtain teaching certificate or license before entering the teaching force. Most science teachers were not certified and licensed in science teaching before joining the teaching force. They enter the profession after successfully completing their first university degrees in school discipline. Moreover, most of Saudi Arabia science teachers do not often attend professional development activities and programs in science. The results of this study fit more compatibly with recent work by Shannag (2013) and his colleagues. Their work has investigated the relationship between science teacher's quality and student achievement on the Trend in International Mathematics and Science Study (TIMSS) test by comparing the differences between grade 8 students' scores of Kingdom of Saudi Arabia and Republic of Singapore. The results of this TIMSS test showed that the Saudi Arabia Grade 8 students have much lower test scores than their Singaporean counterparts. TIMSS findings suggest that there were several reasons such as teacher preparation, background and teacher attendance to professional development programs for the existing differences in student achievement in the two countries.

Missing and lacking appropriate equipment and facilities to teach practical science effectively was the second most important challenges faced by new science teachers who participated in the study. These new science teachers did not have access to either science laboratory or functional library facilities at their schools. They did not have access to some of the most commonly used equipment such as balances, beakers, microscopes, pipets, bulbs, 
thermometers, voltmeter, pulley, connecting leads for circuits, gloves and eye protection. In fact, in Saudi Arabia, many schools did not have science laboratory facilities. In some schools, although buildings were erected for science laboratories or libraries, they are not well equipped. Many schools also lack competent and qualified science laboratory workers to carry out and supervise experiments (Barrow, 1991).

The third major challenge faced by the new science teachers who participated in this study was the shortage of school supplies and instructional materials that reduce students' opportunities to learn science. These new science teachers continue to express concerns related to the deficiency of materials and supplies in their schools because they believe that these issues adversely affect their academic performance. In fact, many schools in Saudi Arabia fail to provide their new science teachers with computers, high speed internet, printers, projectors, latest books, teaching aids and curriculum materials (Hamdan, 2015).

The independent variables, new science teacher gender, school levels and teaching experiences were first analyzed separately to determine the relationship to the dependent variable, level of teaching challenges. To determine any differences associated with gender, school levels and teaching experiences, three steps for analysis of data from teaching challenges were taken. First, the total score of academic challenges were computed by factor level. Second, the score of academic challenges were ranked from the lower to higher scores based on the levels of the three dependent variables. Third, non-parametric statistic tests were performed to evaluate the null hypothesis which stated that there is no main effect of the three factors new science teacher gender, school levels and teaching experiences on science teaching challenge levels.

\section{New Science Teacher Gender}

For factor gender, the scores of academic challenges faced by male and female new science teachers were calculated and reported in Table 4. 
Table 4: Comparative score of academic challenges faced by male and female new science teachers

\begin{tabular}{|r|l|c|c|r|}
\hline $\mathbf{N}$ & Challenges & $\begin{array}{c}\text { Male } \\
\text { new science } \\
\text { teacher } \\
\text { score }\end{array}$ & $\begin{array}{c}\text { Female } \\
\text { New science } \\
\text { teacher } \\
\text { score }\end{array}$ & $\begin{aligned} \text { Total } \\
\text { score }\end{aligned}$ \\
\hline 1 & Teacher preparation program & 62 & 41 & 103 \\
\hline 2 & Knowledge of science subject matter & 85 & 44 & 129 \\
\hline 3 & Effective use of different teaching methods & 77 & 50 & 127 \\
\hline 4 & Planning lessons and school days & 96 & 58 & 154 \\
\hline 5 & Organization of class work & 90 & 58 & 148 \\
\hline 6 & Heavy teaching load & 73 & 51 & 124 \\
\hline 7 & Determining learning level of students & 72 & 50 & 122 \\
\hline 8 & Assessing students' work & 97 & 59 & 156 \\
\hline 9 & Dealing with challenges of individual students & 80 & 55 & 135 \\
\hline 10 & Classroom discipline & 85 & 61 & 146 \\
\hline 11 & Motivating students & 81 & 54 & 135 \\
\hline 12 & Salary and benefits & 71 & 50 & 121 \\
\hline 13 & School equipment and facility & 62 & 42 & 104 \\
\hline 14 & Materials and supplies & 66 & 45 & 111 \\
\hline 15 & Relations with colleagues & 109 & 66 & 175 \\
\hline 16 & Relations with administrators & 96 & 61 & 157 \\
\hline 17 & Relations with student's parents & 93 & 63 & 156 \\
\hline 18 & Awareness of school policies, rules and procedures & 100 & 53 & 153 \\
\hline 19 & Burden of administrative/clerical work & 91 & 60 & 151 \\
\hline 20 & Opportunity to influence over school decision making & 91 & 51 & 142 \\
\hline 21 & Opportunity for professional growth & 82 & 53 & 135 \\
\hline 22 & Community recognition as a professional & 94 & 59 & 153 \\
\hline 23 & Teacher job satisfaction & 93 & 59 & 152 \\
\hline 24 & Being accepted by students & 58 & 151 \\
\hline 25 & Understand teacher performance evaluation system & 60 & 164 \\
\hline & Total score & 143 & 1361 & 3504 \\
\hline
\end{tabular}

The results of the rankings of academic challenges in relation to new science teacher gender are shown in Table 5. 
Table 5: Comparative rankings of academic challenges faced by male and female new science teachers

\begin{tabular}{|c|c|c|c|}
\hline $\mathbf{N}$ & Challenges & $\begin{array}{c}\text { Male } \\
\text { new } \\
\text { science } \\
\text { teacher } \\
\text { rank }\end{array}$ & $\begin{array}{c}\text { Female } \\
\text { new } \\
\text { science } \\
\text { teacher } \\
\text { rank }\end{array}$ \\
\hline 1 & Teacher preparation program & 1.5 & 1 \\
\hline 13 & School equipment and facility & 1.5 & 2 \\
\hline 14 & Materials and supplies & 3 & 4 \\
\hline 12 & Salary and benefits & 4 & 6 \\
\hline 7 & Determining learning level of students & 5 & 6 \\
\hline 6 & Heavy teaching load & 6 & 8.5 \\
\hline 3 & Effective use of different teaching methods & 7 & 6 \\
\hline 9 & Dealing with challenges of individual students & 8 & 13 \\
\hline 11 & Motivating students & 9 & 12 \\
\hline 21 & Opportunity for professional growth & 10 & 10.5 \\
\hline 2 & Knowledge of science subject matter & 11.5 & 3 \\
\hline 10 & Classroom discipline & 11.5 & 22.5 \\
\hline 5 & Organization of class work & 13 & 15 \\
\hline 19 & Burden of administrative/clerical work & 14.5 & 20.5 \\
\hline 20 & Opportunity to influence over school decision making & 14.5 & 8.5 \\
\hline 17 & Relations with student's parents & 17 & 24 \\
\hline 23 & Teacher job satisfaction & 17 & 15 \\
\hline 24 & Being accepted by students & 17 & 18 \\
\hline 22 & Community recognition as a professional & 19 & 18 \\
\hline 4 & Planning lessons and school days & 20.5 & 15 \\
\hline 16 & Relations with administrators & 20.5 & 22.5 \\
\hline 8 & Assessing students' work & 22 & 18 \\
\hline 18 & Awareness of school policies, rules and procedures & 23 & 10.5 \\
\hline 25 & Understand teacher performance evaluation system & 24 & 20.5 \\
\hline 15 & Relations with colleagues & 25 & 25 \\
\hline
\end{tabular}

Tables 4 and 5 revealed that male and female new science teachers have indicated the same top two academic challenges: weak teacher preparation program and lack of appropriate school equipment and facility that they are facing in their profession. Women science teachers 
perceived lack of knowledge in science as a major academic challenge and rank it on the third place, while men identified shortage of materials and supplies for the third place.

The Mann-Whitney test was used to determine if the perceptions of academic challenges faced by new science teachers male and female were significantly different from each other. The results of the Mann-Whitney test was presented in Table 6. The level of significance of MannWhitney hypothesis test was set to 0.05 .

Table 6: Mann-Whitney U Test results on difference of academic challenges faced by male and female new teachers

\begin{tabular}{|r|l|r|r|}
\hline $\mathbf{N}$ & Challenges & $\begin{array}{l}\text { Mann-Whitney } \\
\text { U }\end{array}$ & P-value \\
\hline 1 & Teacher preparation program & 255.5 & 0.409 \\
\hline 2 & Knowledge of science subject matter & 181 & 0.019 \\
\hline 3 & Effective use of different teaching methods & 248 & 0.339 \\
\hline 4 & Planning lessons and school days & 217.5 & 0.114 \\
\hline 5 & Organization of class work & 239.5 & 0.261 \\
\hline 6 & Heavy teaching load & 269.5 & 0.608 \\
\hline 7 & Determining learning level of students & 273.5 & 0.669 \\
\hline 8 & Assessing students' work & 213 & 0.094 \\
\hline 9 & Dealing with challenges of individual students & 270 & 0.619 \\
\hline 10 & lassroom discipline & 189.5 & 0.045 \\
\hline 11 & Motivating students & 255.5 & 0.426 \\
\hline 12 & Salary and benefits & 271.5 & 0.635 \\
\hline 13 & School equipment and facility & 283 & 0.815 \\
\hline 14 & Materials and supplies & 271.5 & 0.636 \\
\hline 15 & Relations with colleagues & 210.5 & 0.078 \\
\hline 16 & Relations with administrators & 230.5 & 0.187 \\
\hline 17 & Relations with student's parents & 255.5 & 0.426 \\
\hline 18 & Awareness of school policies, rules and procedures & 167 & 0.009 \\
\hline 19 & Burden of administrative/clerical work & 234.5 & 0.216 \\
\hline 20 & Opportunity to influence over school decision making & 180 & 0.018 \\
\hline 21 & Opportunity for professional growth & 238 & 0.244 \\
\hline 22 & Community recognition as a professional & 224 & 0.145 \\
\hline 23 & Teacher job satisfaction & 231 & 0.193 \\
\hline 24 & Being accepted by students & 221 & 0.131 \\
\hline 25 & Understand teacher performance evaluation system & 208 & 0.073 \\
\hline & & &
\end{tabular}


The Mann-Whitney U test conducted for gender on academic challenge level was found significant for the following four challenges: awareness of school policies, rules and procedures $(\mathrm{p}=0.009)$, opportunity to influence over school decision making $(\mathrm{p}=0.018)$; knowledge of science subject matter $(p=0.019)$, and classroom discipline $(p=0.045)$. The female new science teachers, who took the survey, believed that they don't have sufficient knowledge about the science subject. Moreover, they felt that their school administrators did not make enough efforts to explain to them existing school policies, rules and procedures that were put in place in their workplaces. These female new science teachers also felt powerless at their workplace because their thoughts, concerns, feelings, emotions and feedback did not have any influences on decisions made by the school administrators. On the other hand, the men new science teachers were wrestling more than their female colleagues with classroom discipline challenges.

\section{New Science Teacher School Level}

Table 7 presents the results of the score of academic challenges faced by novice teachers who teach science subject to elementary, middle and high schools. The rankings of academic challenges faced by elementary, middle and high school new science teachers are summarized in Table 8 . 
Table 7: Comparative score of teaching challenges faced by new science teachers in elementary, middle and high school

\begin{tabular}{|c|c|c|c|c|c|}
\hline $\mathbf{N}$ & Challenges & $\begin{array}{c}\text { Elementary } \\
\text { school } \\
\text { new } \\
\text { science } \\
\text { teacher } \\
\text { score }\end{array}$ & $\begin{array}{c}\text { Middle } \\
\text { school } \\
\text { new } \\
\text { science } \\
\text { teacher } \\
\text { score }\end{array}$ & $\begin{array}{l}\text { High } \\
\text { school } \\
\text { new } \\
\text { science } \\
\text { teacher } \\
\text { score }\end{array}$ & $\begin{array}{l}\text { Total } \\
\text { score }\end{array}$ \\
\hline 1 & Teacher preparation program & 12 & 27 & 64 & 103 \\
\hline 2 & Knowledge of science subject matter & 20 & 37 & 72 & 129 \\
\hline 3 & Effective use of different teaching methods & 18 & 35 & 74 & 127 \\
\hline 4 & Planning lessons and school days & 16 & 45 & 93 & 154 \\
\hline 5 & Organization of class work & 16 & 45 & 87 & 148 \\
\hline 6 & Heavy teaching load & 17 & 37 & 70 & 124 \\
\hline 7 & Determining learning level of students & 21 & 33 & 68 & 122 \\
\hline 8 & Assessing students' work & 15 & 46 & 95 & 156 \\
\hline 9 & $\begin{array}{l}\text { Dealing with challenges of individual } \\
\text { students }\end{array}$ & 21 & 40 & 74 & 135 \\
\hline 10 & Classroom discipline & 20 & 39 & 87 & 146 \\
\hline 11 & Motivating students & 22 & 38 & 75 & 135 \\
\hline 12 & Salary and benefits & 19 & 37 & 65 & 121 \\
\hline 13 & School equipment and facility & 13 & 30 & 61 & 104 \\
\hline 14 & Materials and supplies & 13 & 34 & 64 & 111 \\
\hline 15 & Relations with colleagues & 22 & 51 & 102 & 175 \\
\hline 16 & Relations with administrators & 22 & 46 & 89 & 157 \\
\hline 17 & Relations with student's parents & 20 & 49 & 87 & 156 \\
\hline 18 & $\begin{array}{l}\text { Awareness of school policies, rules and } \\
\text { procedures }\end{array}$ & 19 & 50 & 84 & 153 \\
\hline 19 & Burden of administrative/clerical work & 19 & 44 & 88 & 151 \\
\hline 20 & $\begin{array}{l}\text { Opportunity to influence over school } \\
\text { decision making }\end{array}$ & 16 & 46 & 80 & 142 \\
\hline 21 & Opportunity for professional growth & 20 & 40 & 75 & 135 \\
\hline 22 & Community recognition as a professional & 22 & 40 & 91 & 153 \\
\hline 23 & Teacher job satisfaction & 25 & 44 & 83 & 152 \\
\hline 24 & Being accepted by students & 23 & 42 & 86 & 151 \\
\hline 25 & $\begin{array}{l}\text { Understand teacher performance evaluation } \\
\text { system }\end{array}$ & 21 & 46 & 97 & 164 \\
\hline & Total score & 472 & 1021 & 2011 & 3504 \\
\hline
\end{tabular}


Table 8: Comparative rankings of academic challenges faced by new science teachers at the elementary, secondary and high school levels

\begin{tabular}{|c|c|c|c|c|}
\hline $\mathbf{N}$ & Challenges & $\begin{array}{c}\text { Elementary } \\
\text { school } \\
\text { new } \\
\text { science } \\
\text { teacher } \\
\text { Rank }\end{array}$ & $\begin{array}{c}\text { Middle } \\
\text { school } \\
\text { new } \\
\text { science } \\
\text { teacher } \\
\text { Rank }\end{array}$ & $\begin{array}{c}\text { High } \\
\text { school } \\
\text { new } \\
\text { science } \\
\text { teacher } \\
\text { Rank }\end{array}$ \\
\hline 1 & Teacher preparation program & 1 & 1 & 2.5 \\
\hline 13 & School equipment and facility & 2.5 & 2 & 1 \\
\hline 14 & Materials and supplies & 2.5 & 4 & 2.5 \\
\hline 8 & Assessing students' work & 4 & 20.5 & 23 \\
\hline 4 & Planning lessons and school days & 5.5 & 17.5 & 22 \\
\hline 5 & Organization of class work & 5.5 & 17.5 & 17 \\
\hline 20 & Opportunity to influence over school decision & 7 & 20.5 & 12 \\
\hline 6 & Heavy teaching load & 8 & 7 & 6 \\
\hline 3 & Effective use of teaching methods & 9 & 5 & 8.5 \\
\hline 12 & Salary and benefits & 11 & 7 & 4 \\
\hline 18 & Awareness of school policies, rules and procedures & 11 & 24 & 14 \\
\hline 19 & Burden of administrative/clerical work & 11 & 15.5 & 19 \\
\hline 2 & Knowledge of science subject matter & 14.5 & 7 & 7 \\
\hline 10 & Classroom discipline & 14.5 & 10 & 17 \\
\hline 17 & Relations with student's parents & 14.5 & 23 & 17 \\
\hline 21 & Opportunity for professional growth & 14.5 & 12 & 10.5 \\
\hline 7 & Determining learning level of students & 17.5 & 3 & 5 \\
\hline 9 & Dealing with challenges of individual students & 17.5 & 12 & 8.5 \\
\hline 25 & Understand teacher evaluation performance system & 19 & 20.5 & 24 \\
\hline 11 & Motivating students & 21.5 & 9 & 10.5 \\
\hline 15 & Relations with colleagues & 21.5 & 25 & 25 \\
\hline 16 & Relations with administrators & 21.5 & 20.5 & 20 \\
\hline 22 & Community recognition as a professional & 21.5 & 12 & 21 \\
\hline 24 & Being accepted by students & 24 & 14 & 15 \\
\hline 23 & Teacher job satisfaction & 25 & 15.5 & 13 \\
\hline
\end{tabular}

The poor quality of teacher training programs was ranked the most significant challenge that is encountered by elementary and middle school teachers. According to high school science teachers, poor school facilities and equipment was the biggest challenge that they face. Although, 
teacher preparation program, school equipment and facility and materials and supplies were ranked in different order of importance, they were identified as top three biggest science teaching challenges by elementary and high school new teachers. Middle school beginning science teachers gave significantly higher challenge seriousness ratings for determining the learning level of students and use of effective science teaching strategies.

A Kruskal-Wallis non-parametric analysis of variance was used to analyze the disparity in perception of academic challenges among elementary, secondary and high school novice science teachers. The level of significance of Kruskal-Wallis hypotheses tests were set to 0.05 . The results of the Kruskal-Wallis tests are shown in Table 9.

Table 9: Kruskal Wallis H Test results on difference of academic challenges faced by new science teachers at the elementary, middle and high school levels

\begin{tabular}{|r|l|r|r|}
\hline $\mathbf{N}$ & Challenges & $\begin{array}{l}\text { Kruskal-Wallis } \\
\text { H }\end{array}$ & $\begin{array}{l}\text { P- } \\
\text { value }\end{array}$ \\
\hline 1 & Teacher preparation program & 1.169 & 0.557 \\
\hline 2 & Knowledge of science subject matter & 3.203 & 0.202 \\
\hline 3 & Effective use of different teaching methods & 4.023 & 0.134 \\
\hline 4 & Planning lessons and school days & 7.137 & 0.028 \\
\hline 5 & Organization of class work & 6.547 & 0.038 \\
\hline 6 & Heavy teaching load & 3.042 & 0.218 \\
\hline 7 & Determining learning level of students & 8.782 & 0.012 \\
\hline 8 & Assessing students' work & 9.088 & 0.011 \\
\hline 9 & Dealing with challenges of individual students & 2.814 & 0.245 \\
\hline 10 & Classroom discipline & 1.405 & 0.495 \\
\hline 11 & Motivating students & 8.547 & 0.019 \\
\hline 12 & Salary and benefits & 3.995 & 0.138 \\
\hline 13 & School equipment and facility & 2.152 & 0.341 \\
\hline 14 & Materials and supplies & 1.254 & 0.534 \\
\hline 15 & Relations with colleagues & 4.2 & 0.122 \\
\hline 16 & Relations with administrators & 3.528 & 0.171 \\
\hline 17 & Relations with student's parents & 2.477 & 0.29 \\
\hline 18 & Awareness of school policies, rules and procedures & 8.457 & 0.014 \\
\hline
\end{tabular}




\begin{tabular}{|r|l|r|l|}
\hline $\mathbf{N}$ & Challenges & Kruskal-Wallis & $\begin{array}{l}\text { P- } \\
\text { value }\end{array}$ \\
\hline 19 & Burden of administrative/clerical work & 3.258 & 0.196 \\
\hline 20 & Opportunity to influence over school decision making & 8.567 & 0.014 \\
\hline 21 & Opportunity for professional growth & 1.712 & 0.425 \\
\hline 22 & Community recognition as a professional & 4.861 & 0.088 \\
\hline 23 & Teacher job satisfaction & 2.15 & 0.341 \\
\hline 24 & Being accepted by students & 5.202 & 0.074 \\
\hline 25 & Understand teacher performance evaluation system & 3.619 & 0.164 \\
\hline
\end{tabular}

The results from Table 9 reveal a significant rank order effect for science teacher school levels in seven areas of challenges that faced new science teachers: assessing students' work $(p=0.011)$, determining learning level of students $(p=0.012)$, opportunity to influence over school decision $(p=0.014)$, awareness of school policies, rules and procedures $(p=0.014)$, motivating students $(p=0.019)$, planning lessons and school days $(p=0.028)$, and organization of class work $(\mathrm{p}=0.038)$.

In contrast to middle and high school teachers, elementary school teachers perceived the process of assessing students' work $(p=0.011)$, the organization of class work $(p=0.038)$ and the planning of science lessons $(\mathrm{p}=0.028)$ as highly challenging tasks. Elementary teachers, who participated in the study, believed that they were not given opportunity to influence the decision-making process at their schools. Compared to elementary school science teachers, middle and high school beginning science teachers gave higher rankings not only to the challenge of motivating students $(\mathrm{p}=0.019)$, but also to the challenge of determining the appropriate science learning level of the students $(p=0.012)$. Elementary and high school novice science teachers were more challenged with the lack of awareness of their school policies, rules and procedures. 


\section{New Science Teacher Teaching Experience}

Finally, the score of academic challenges faced by first, second and third year science teachers are summarized in Table 10. The results of the rankings of academic challenges in relation to new science teacher teaching experiences are shown in Table 11. Findings suggest that there are some differences in academic challenge rankings among first, second and third year science teachers. To determine whether or not the differences in perceptions of academic challenges among first, second and third year science teachers are statistically significant, the Kruskal-Wallis non-parametric analysis of variance test was used. The Kruskal-Wallis test results are presented in Table 12. Table 12 indicates a significant rank order for challenge related to the motivation of students. First year science teachers gave the highest rankings to the weakness of teacher preparation programs, assessing student's learning level and lack of knowledge of science subject matter. In contrast to first year science teachers, second year science teachers perceived motivating students, lacking opportunities to growth professionally, missing adequate school equipment and facilities and having heavy teaching loads as their top four challenges. For third year science teachers, lack of adequate school equipment and facilities, weakness of teacher preparation programs and shortage of school materials and supplies are the top three challenges that they face in their classrooms. 
Table 10: Comparative scores of academic challenges faced by first, second and third years new science teachers

\begin{tabular}{|c|c|c|c|c|c|}
\hline $\mathbf{N}$ & Challenges & $\begin{array}{c}\text { First } \\
\text { year } \\
\text { teacher } \\
\text { score }\end{array}$ & $\begin{array}{l}\text { Second } \\
\text { year } \\
\text { teacher } \\
\text { score }\end{array}$ & $\begin{array}{l}\text { Third } \\
\text { year } \\
\text { teacher } \\
\text { score }\end{array}$ & $\begin{array}{l}\text { Total } \\
\text { score }\end{array}$ \\
\hline 1 & Teacher preparation program & 14 & 22 & 67 & 103 \\
\hline 2 & Knowledge of science subject matter & 19 & 24 & 86 & 129 \\
\hline 3 & Effective use of different teaching methods & 24 & 22 & 81 & 127 \\
\hline 4 & Planning lessons and school days & 30 & 27 & 97 & 154 \\
\hline 5 & Organization of class work & 22 & 29 & 97 & 148 \\
\hline 6 & 6. Heavy teaching load & 26 & 20 & 78 & 124 \\
\hline 7 & Determining learning level of students & 17 & 24 & 81 & 122 \\
\hline 8 & Assessing students' work & 27 & 26 & 103 & 156 \\
\hline 9 & Dealing with challenges of individual students & 23 & 21 & 91 & 135 \\
\hline 10 & Classroom discipline & 24 & 23 & 99 & 146 \\
\hline 11 & Motivating students & 27 & 16 & 92 & 135 \\
\hline 12 & Salary and benefits & 24 & 23 & 74 & 121 \\
\hline 13 & School equipment and facility & 22 & 20 & 62 & 104 \\
\hline 14 & Materials and supplies & 20 & 23 & 68 & 111 \\
\hline 15 & Relations with colleagues & 30 & 34 & 111 & 175 \\
\hline 16 & Relations with administrators & 28 & 29 & 100 & 157 \\
\hline 17 & Relations with student's parents & 26 & 26 & 104 & 156 \\
\hline 18 & $\begin{array}{l}\text { Awareness of school policies, rules and } \\
\text { procedures }\end{array}$ & 28 & 27 & 98 & 153 \\
\hline 19 & Burden of administrative/clerical work & 29 & 27 & 95 & 151 \\
\hline 20 & $\begin{array}{l}\text { Opportunity to influence over school decision } \\
\text { making }\end{array}$ & 24 & 31 & 87 & 142 \\
\hline 21 & Opportunity for professional growth & 23 & 19 & 93 & 135 \\
\hline 22 & Community recognition as a professional & 33 & 28 & 92 & 153 \\
\hline 23 & Teacher job satisfaction & 28 & 26 & 98 & 152 \\
\hline 24 & Being accepted by students & 28 & 27 & 96 & 151 \\
\hline \multirow[t]{2}{*}{25} & $\begin{array}{l}\text { Understand teacher performance evaluation } \\
\text { system }\end{array}$ & 28 & 31 & 105 & 164 \\
\hline & Total Score & 624 & 625 & 2255 & 3504 \\
\hline
\end{tabular}


Table 11: Comparative rankings of academic challenges faced by first, second and third years new science teachers

\begin{tabular}{|c|c|c|c|c|}
\hline $\mathbf{N}$ & Challenges & $\begin{array}{c}\text { First } \\
\text { year } \\
\text { teacher } \\
\text { rank }\end{array}$ & $\begin{array}{l}\text { Second } \\
\text { year } \\
\text { teacher } \\
\text { rank }\end{array}$ & $\begin{array}{l}\text { Third } \\
\text { year } \\
\text { teacher } \\
\text { rank }\end{array}$ \\
\hline 1 & Teacher preparation program & 1 & 6.5 & 2 \\
\hline 7 & Determining learning level of students & 2 & 11.5 & 6.5 \\
\hline 2 & 2. Knowledge of science subject matter & 3 & 11.5 & 8 \\
\hline 14 & Materials and supplies & 4 & 9 & 3 \\
\hline 5 & Organization of class work & 5.5 & 21.5 & 16.5 \\
\hline 13 & School equipment and facility & 5.5 & 3.5 & 1 \\
\hline 9 & Dealing with challenges of individual students & 7.5 & 5 & 10 \\
\hline 21 & Opportunity for professional growth & 7.5 & 2 & 13 \\
\hline 3 & Effective use of different teaching methods & 10.5 & 6.5 & 6.5 \\
\hline 10 & Classroom discipline & 10.5 & 9 & 20 \\
\hline 12 & Salary and benefits & 10.5 & 9 & 4 \\
\hline 20 & $\begin{array}{l}\text { Opportunity to influence over school decision } \\
\text { making }\end{array}$ & 10.5 & 23.5 & 9 \\
\hline 6 & Heavy teaching load & 13.5 & 3.5 & 5 \\
\hline 17 & Relations with student's parents & 13.5 & 14 & 23 \\
\hline 8 & Assessing students' work & 15.5 & 14 & 22 \\
\hline 11 & Motivating students & 15.5 & 1 & 11.5 \\
\hline 16 & Relations with administrators & 19 & 21.5 & 21 \\
\hline 18 & $\begin{array}{l}\text { Awareness of school policies, rules and } \\
\text { procedures }\end{array}$ & 19 & 17.5 & 18.5 \\
\hline 23 & Teacher job satisfaction & 19 & 14 & 18.5 \\
\hline 24 & Being accepted by students & 19 & 17.5 & 15 \\
\hline 25 & $\begin{array}{l}\text { Understand teacher performance evaluation } \\
\text { system }\end{array}$ & 19 & 23.5 & 24 \\
\hline 19 & Burden of administrative/clerical work & 22 & 17.5 & 14 \\
\hline 4 & Planning lessons and school days & 23.5 & 17.5 & 16.5 \\
\hline 15 & Relations with colleagues & 23.5 & 25 & 25 \\
\hline 22 & Community recognition as a professional & 25 & 20 & 11.5 \\
\hline
\end{tabular}


Table 12: Kruskal Wallis H Test results on difference of academic challenges faced by first, second and third year new science teachers

\begin{tabular}{|r|l|r|r|}
\hline $\mathbf{N}$ & Challenges & Kruskal-Wallis H & P-value \\
\hline 1 & Teacher preparation program & 1.689 & 0.43 \\
\hline 2 & Knowledge of science subject matter & 0.296 & 0.863 \\
\hline 3 & Effective use of different teaching methods & 0.711 & 0.701 \\
\hline 4 & Planning lessons and school days & 1.929 & 0.381 \\
\hline 5 & Organization of class work & 0.467 & 0.792 \\
\hline 6 & Heavy teaching load & 4.658 & 0.097 \\
\hline 7 & Determining learning level of students & 0.894 & 0.639 \\
\hline 8 & Assessing students' work & 0.59 & 0.745 \\
\hline 9 & Dealing with challenges of individual students & 0.935 & 0.627 \\
\hline 10 & llassroom discipline & 0.928 & 0.629 \\
\hline 11 & Motivating students & 6.157 & 0.046 \\
\hline 12 & Salary and benefits & 1.56 & 0.458 \\
\hline 13 & School equipment and facility & 4.673 & 0.097 \\
\hline 14 & Materials and supplies & 1.11 & 0.574 \\
\hline 15 & Relations with colleagues & 0.308 & 0.857 \\
\hline 16 & Relations with administrators & 0.515 & 0.773 \\
\hline 17 & Relations with student's parents & 0.491 & 0.782 \\
\hline 18 & Awareness of school policies, rules and procedures & 0.742 & 0.69 \\
\hline 19 & Burden of administrative/clerical work & 1.493 & 0.474 \\
\hline 20 & Opportunity to influence over school decision making & 2.271 & 0.321 \\
\hline 21 & Opportunity for professional growth & 2.76 & 0.252 \\
\hline 22 & Community recognition as a professional & 5.976 & 0.05 \\
\hline 23 & Teacher job satisfaction & 0.848 & 0.654 \\
\hline 24 & Being accepted by students & 0.942 & 0.624 \\
\hline 25 & Understand teacher performance evaluation system & 0.198 & 0.906 \\
\hline & & & \\
\hline
\end{tabular}




\section{Research Question 2 - Science Classroom Behavioral Challenges}

The second research question was about investigating the level of concern of behavioral challenges encountered by new science teachers in their classroom. Means and standard deviadeviations were computed for each item included in the third survey. Table 13 shows means and standard deviations of each behavioral challenge faced by a new science teacher. The results of Table 13 report that the mean scores fall between $1.75-3.75$ and the standard deviations fall between $1.09-1.60$. It is important to note that lower mean scores are indicators of a higher level of behavioral challenge, while higher mean values reveal a lower level of behavioral challenge. To make it convenient to analyze the results, the behavioral challenges encountered by new science teachers in their classrooms were ranked from the lowest mean value to the highest mean value of the level of the challenge, as shown in Table 13.

Table 13: Means and standard deviations of science classroom behavioral challenges

\begin{tabular}{|r|l|r|r|c|}
\hline $\mathbf{N}$ & Challenges & Mean & $\begin{array}{c}\text { Std. } \\
\text { Deviation }\end{array}$ & Rank \\
\hline 11 & Excessive absences & 1.7551 & 1.09031 & 1 \\
\hline 1 & Students do not appear ready to learn science & 2.1633 & 1.12448 & 2 \\
\hline 3 & Indifference to science lessons & 2.1633 & 1.16094 & 3 \\
\hline 4 & Students do not have correct supplies ready & 2.3061 & 1.15838 & 4 \\
\hline 2 & Students have negative ideas about science lessons & 2.3265 & 1.23132 & 5 \\
\hline 6 & Lack of motivation to learn science & 2.3673 & 1.23649 & 6 \\
\hline 8 & Attempt of cheating during tests or examinations & 2.3878 & 1.39667 & 7 \\
\hline 12 & Students come late to science lessons & 2.449 & 1.27576 & 8 \\
\hline 7 & Nonparticipation in classroom science activities and labs & 2.4898 & 1.3248 & 9 \\
\hline 9 & $\begin{array}{l}\text { Students are chatting among themselves during science } \\
\text { class }\end{array}$ & 2.4898 & 1.38628 & 10 \\
\hline 5 & $\begin{array}{l}\text { Students ignore the teacher instructions, orders and their } \\
\text { comments }\end{array}$ & 2.5102 & 1.30898 & 11 \\
\hline 10 & Students interrupt others & 2.5918 & 1.33726 & 12 \\
\hline 20 & $\begin{array}{l}\text { Lack of concern in performance of science activities and } \\
\text { homework }\end{array}$ & 2.5918 & 1.33726 & 13 \\
\hline
\end{tabular}




\begin{tabular}{|r|l|r|r|c|}
\hline $\mathbf{N}$ & Challenges & Mean & $\begin{array}{c}\text { Std. } \\
\text { Deviation }\end{array}$ & Rank \\
\hline 19 & Students do not complete science assignment on time & 2.6327 & 1.37982 & 14 \\
\hline 18 & Inappropriate out of seat behavioral & 2.898 & 1.43244 & 15 \\
\hline 13 & Sleeping during science lessons & 3 & 1.36931 & 16 \\
\hline 14 & Leaving class early & 3.2449 & 1.40728 & 17 \\
\hline 16 & Students reply to the teacher in the impolite manner & 3.2653 & 1.60436 & 18 \\
\hline 15 & Playing and using mobile phones during science class & 3.5306 & 1.52892 & 19 \\
\hline 17 & Harassment and abuse of other students & 3.551 & 1.50085 & 20 \\
\hline
\end{tabular}

The three most behavioral challenges encountered by new science teachers who participated in our survey were: student absenteeism $($ mean $=1.7551)$, student lack of readiness to learn science $($ mean $=2.1633)$ and student indifference to science $($ mean $=2.1633)$.

New science teachers responding to the survey indicated that lots of their students were missing lots of school days. They felt that "student excessive absences" is the number one behavioral challenges that these teachers face. According to the education rules and school policies of the Kingdom (Toumi, 2014), excessive student absenteeism in schools is defined as missing more than two consecutive weeks or 30 days of school over the full academic year, including both excused and unexcused absences. In recent years, several schools have reported that student absentee rates increase dramatically just before and after holidays. During the 2012-2013 academic year, before Haj holidays, the absenteeism percentage was between $70 \%$ to $100 \%$ in several schools in different provinces of Saudi Arabia (Saudi Gazette, 2012). In addition to the extension of their holidays and days off, there are many other reasons why students miss school. Every so often, students cannot attend school because of injury or sickness such as flu, cold and other childhood ailments. On other occasions, students do not show up to class to avoid real and perceived embarrassment situations in school or because they did not complete their homework assignments on the due date. Sometimes, students choose not to attend schools 
because they would prefer to be elsewhere and rather be doing something else and they do not see the value in school attendance or because they do not want to put the effort necessary to get them to school (Alsuiadi, 2015). Some parents who do not value the importance of education for their children and have negative experience themselves going through schools allow their children to miss schools (Kozinetz, 1995). Simply put, childhood illnesses, laziness, mismanagement of time, reliance on others, parental apathy, student and parental educational negligence contribute to excessive student absenteeism phenomenon (Ndaayezwi, 2003).

A number of studies have revealed that students with poor attendance have the lowest academic achievement and performance and often end up dropping out of school (Boloz, 1983; Dekalb, 1999). Student with higher truancy rates also have quite low self-esteem and are more likely to settle for much lower salary employments (United States Department of Education, 1996). In addition, excessive absenteeism affects the academic achievement of students who attend class regularly, school administration and teacher instruction and effectiveness (United States Department of Justice, 2001; Zamudio, 2014).

The second behavioral challenge faced by these new science teachers in their classroom is student lack of readiness to learn science. The new science teachers, who participated in the study, revealed that their students do not have the required level to undertake the learning of science. They strongly criticized the Saudi Arabia's education system for allowing students to continue in the next grade despite the fact that these students failed to acquire science skills in their current grade. Then, once students make it to the next grade regardless of their academic achievement, they are more likely to struggle understanding the new set of science key concepts and skills. Although the Kingdom of Saudi Arabia devotes greater funding on education improving literacy rate to $99 \%$, the Saudi schools still lack quality science teaching (Hamdan, 
2015; Jiffry, 2013). Recently, a set of standardized test, the Trends in International Mathematics and Science Study (TIMSS), was administered to 13 year olds children in several countries. The results of the tests show that more than $50 \%$ of the Saudi children fail to reach the low benchmarks against 12\% of English and 1\% of South Korean ones (Jiffry, 2013). A report from the Center for Universal Education at the Brookings Institution show that Arab children and youth suffer from a significant deficit of educational foundation skills that would put them at a long-term disadvantage in becoming productive citizens (Steer, 2014). The quality of science teaching remains an important influence of school readiness.

The new science teachers felt that student lack of interest in science is the third behavioral challenge encountered by these teachers in their classroom. They believed that for most of their students learning science is too difficult, boring, uninteresting, inappropriate and useless in all walks of life. Therefore, these students become convinced that they do not possess the skills and abilities necessary to be good at science. Negative or hostile student attitudes toward science are detrimental to students' participation and achievement in science class (IAEP, 1992; Neathery, 1997; Weiss, 1987). Moreover, these new science teachers felt that their students who lacked the background knowledge necessary in science, were experiencing difficulties to find that science is fun, exciting and meaningful. There are many studies that establish a correlation between knowledge in the field and interest in the field (Alexander, Jetton, \& Kulikowich, 1995; Tobias, 1994). According to Bergin (1999), factors influencing on classroom interest fall into two broad categories:

(1) Individual factors - Dispositional preferences that are person-centered. These factors are background knowledge, competence, emotions, utility-goal relevance and belongingness.

(2) Situational factors - Environmental conditions, activities and content that were interesting to many individuals. Situational factors include 
hands-on activities, social interaction, food, discrepancy, novelty, modelling, games and puzzles, content, biophilia, fantasy, humor, and narrative.

\section{Data Analysis}

The descriptive statistics data were analyzed using independent t-tests and ANOVA. The analysis of data presents the relationship of the independent variables of new science teacher gender, school level and years of experience to the dependent variable of level of behavioral challenges. To validate the significance of the relationship between the independent variables on the dependent variable, the significance level of 0.05 was used for hypothesis testing.

\section{New Science Teacher Gender}

Table 14 presents the means and standard deviations of the level of behavioral challenges across men and women new science teachers. Overall, both men and women new science teachers perceived student absenteeism as the most important challenge encountered in their classrooms. The second and third most important behavioral classroom challenges encountered by male science teachers were: lack of student readiness to learn science and student indifference to science lessons. Working with defiant students who ignore teacher instructions, orders and comments and who come late to science lessons were the second and third most important behavioral classroom challenges that female science teachers faced in their classrooms.

Table 14: Means and standard deviations of science classroom behavioral challenges by gender

\begin{tabular}{|r|l|l|r|r|}
\hline $\mathbf{N}$ & Challenges & Gender & Mean & $\begin{array}{c}\text { Standard } \\
\text { Deviation }\end{array}$ \\
\hline 1 & Students do not appear ready to learn science & Male & 2.2143 & 1.22798 \\
\cline { 3 - 5 } & & Female & 2.0952 & 0.99523 \\
\hline 2 & Students have negative ideas about science lessons & Male & 2.5357 & 1.37389 \\
\cline { 3 - 5 } & & Female & 2.0476 & 0.97346 \\
\hline 3 & Indifference to science lessons & Male & 2.2143 & 1.31535 \\
\cline { 3 - 5 } & & Female & 2.0952 & 0.94365 \\
\hline
\end{tabular}




\begin{tabular}{|c|c|c|c|c|}
\hline $\mathbf{N}$ & Challenges & Gender & Mean & $\begin{array}{l}\text { Standard } \\
\text { Deviation }\end{array}$ \\
\hline \multirow{2}{*}{4} & \multirow{2}{*}{ Students do not have correct supplies ready } & Male & 2.3929 & 1.28638 \\
\hline & & Female & 2.1905 & 0.98077 \\
\hline \multirow{2}{*}{5} & \multirow{2}{*}{$\begin{array}{l}\text { Students ignore the teacher instructions, orders and their } \\
\text { comments }\end{array}$} & Male & 2.9643 & 1.31887 \\
\hline & & Female & 1.9048 & 1.04426 \\
\hline \multirow{2}{*}{6} & \multirow{2}{*}{ Lack of motivation to learn science } & Male & 2.5714 & 1.34519 \\
\hline & & Female & 2.0952 & 1.04426 \\
\hline \multirow{2}{*}{7} & \multirow{2}{*}{ Nonparticipation in classroom science activities and labs } & Male & 2.7143 & 1.38396 \\
\hline & & Female & 2.1905 & 1.20909 \\
\hline \multirow{2}{*}{8} & \multirow{2}{*}{ Attempts of cheating during tests or examinations } & Male & 2.25 & 1.32288 \\
\hline & & Female & 2.5714 & 1.50238 \\
\hline \multirow{2}{*}{9} & \multirow{2}{*}{$\begin{array}{l}\text { Students are chatting among themselves during science } \\
\text { class }\end{array}$} & Male & 2.5357 & 1.31887 \\
\hline & & Female & 2.4286 & 1.50238 \\
\hline \multirow{2}{*}{10} & \multirow{2}{*}{ Students interrupt others } & Male & 2.75 & 1.2057 \\
\hline & & Female & 2.381 & 1.49921 \\
\hline \multirow{2}{*}{11} & \multirow{2}{*}{ Excessive absences } & Male & 2 & 1.18634 \\
\hline & & Female & 1.4286 & 0.87014 \\
\hline \multirow{2}{*}{12} & \multirow{2}{*}{ Students come late to science lessons } & Male & 2.7857 & 1.25778 \\
\hline & & Female & 2 & 1.18322 \\
\hline \multirow{2}{*}{13} & \multirow{2}{*}{ Sleeping during science lessons } & Male & 3.0357 & 1.2013 \\
\hline & & Female & 2.9524 & 1.59613 \\
\hline \multirow{2}{*}{14} & \multirow{2}{*}{ Leaving class early } & Male & 3.3571 & 1.33927 \\
\hline & & Female & 3.0952 & 1.51343 \\
\hline \multirow{2}{*}{15} & \multirow{2}{*}{ Playing and using mobile phones during science class } & Male & 3.6786 & 1.33482 \\
\hline & & Female & 3.3333 & 1.77012 \\
\hline \multirow{2}{*}{16} & \multirow{2}{*}{ Students reply to the teacher in the impolite manner } & Male & 3.5357 & 1.45251 \\
\hline & & Female & 2.9048 & 1.75798 \\
\hline \multirow{2}{*}{17} & \multirow{2}{*}{ Harassment and abuse of other students } & Male & 3.75 & 1.2057 \\
\hline & & Female & 3.2857 & 1.82052 \\
\hline \multirow{2}{*}{18} & Inannronriate out of seat hehavioral & Male & 2.8929 & 1.34272 \\
\hline & Inappropriate out of seat behavioral & Female & 2.9048 & 1.57812 \\
\hline 19 & Students do not complete science occionments on time & Male & 2.8214 & 1.44154 \\
\hline & students do not complete science assignments on time & Female & 2.381 & 1.2836 \\
\hline 20 & Lack of concern in performance of science activities and & Male & 2.7857 & 1.44932 \\
\hline & homework & Female & 2.3333 & 1.1547 \\
\hline
\end{tabular}


The results of the confidence intervals of the mean differences and t-tests that were performed on the independent variable of new science teacher gender and the dependent variable of level of behavioral challenges were reported in Table 15. The t-test and confidence interval of the mean differences results reveal that there is a significant difference between men and women science teachers in their perception of two behavioral classroom challenges: student noncompliance $(p=0.004)$ and student lateness to science lessons $(p=0.031)$. In contrast to female science teachers, male science teachers gave lower rankings to the challenges related to students ignoring instructions, orders and comments and coming late to their science class.

Table 15: Independent T-test results on difference of science classroom behavioral challenges faced by male and female new teachers

\begin{tabular}{|c|c|c|c|c|c|c|}
\hline \multirow[b]{2}{*}{$\mathrm{N}$} & \multirow[t]{2}{*}{ Challenges } & \multirow[t]{2}{*}{$\mathbf{T}$} & \multirow[t]{2}{*}{ P-value } & \multirow[t]{2}{*}{$\begin{array}{l}\text { Mean } \\
\text { Difference }\end{array}$} & \multicolumn{2}{|c|}{$\begin{array}{l}95 \% \text { Confidence } \\
\text { Interval of the } \\
\text { Difference }\end{array}$} \\
\hline & & & & & Lower & Upper \\
\hline 1 & Students do not appear ready to learn science & 0.363 & 0.718 & 0.11905 & -0.53997 & 0.77806 \\
\hline 2 & $\begin{array}{l}\text { Students have negative ideas about science } \\
\text { lessons }\end{array}$ & 1.386 & 0.172 & 0.4881 & -0.22021 & 1.1964 \\
\hline 3 & Indifference to science lessons & 0.352 & 0.726 & 0.11905 & -0.5614 & 0.79949 \\
\hline 4 & Students do not have correct supplies ready & 0.601 & 0.551 & 0.20238 & -0.47485 & 0.87962 \\
\hline 5 & $\begin{array}{l}\text { Students ignore the teacher instructions, orders } \\
\text { and their comments }\end{array}$ & 3.034 & 0.004 & 1.05952 & 0.35703 & 1.76202 \\
\hline 6 & Lack of motivation to learn science & 1.345 & 0.185 & 0.47619 & -0.23591 & 1.18829 \\
\hline 7 & $\begin{array}{l}\text { Nonparticipation in classroom science activities } \\
\text { and labs }\end{array}$ & 1.383 & 0.173 & 0.52381 & -0.23835 & 1.28597 \\
\hline 8 & $\begin{array}{l}\text { Attempts of cheating during tests or } \\
\text { examinations }\end{array}$ & -0.794 & 0.431 & -0.32143 & -1.13567 & 0.49281 \\
\hline 9 & $\begin{array}{l}\text { Students are chatting among themselves during } \\
\text { science class }\end{array}$ & 0.265 & 0.792 & 0.10714 & -0.70584 & 0.92012 \\
\hline 10 & Students interrupt others & 0.955 & 0.344 & 0.36905 & -0.40826 & 1.14636 \\
\hline 11 & Excessive absences & 1.862 & 0.069 & 0.57143 & -0.0461 & 1.18895 \\
\hline 12 & Students come late to science lessons & 2.219 & 0.031 & 0.78571 & 0.07338 & 1.49805 \\
\hline 13 & Sleeping during science lessons & 0.209 & 0.836 & 0.08333 & -0.71992 & 0.88659 \\
\hline 14 & Leaving class early & 0.641 & 0.525 & 0.2619 & -0.56042 & 1.08423 \\
\hline 15 & $\begin{array}{l}\text { Playing and using mobile phones during science } \\
\text { class }\end{array}$ & 0.779 & 0.44 & 0.34524 & -0.54632 & 1.2368 \\
\hline
\end{tabular}




\begin{tabular}{|l|l|r|r|r|r|l|}
\hline & & & P-value & \multicolumn{2}{l|}{$\begin{array}{l}\text { Mean } \\
\text { Difference }\end{array}$} & \multicolumn{2}{l|}{$\begin{array}{l}\text { 95\% Confidence } \\
\text { Interval of the } \\
\text { Difference }\end{array}$} \\
\cline { 5 - 7 } $\mathrm{N}$ & Challenges & $\mathbf{T}$ & & & Lower & Upper \\
\hline 16 & $\begin{array}{l}\text { Students reply to the teacher in the impolite } \\
\text { manner }\end{array}$ & 1.375 & 0.176 & 0.63095 & -0.29224 & 1.55415 \\
\hline 17 & Harassment and abuse of other students & 1.073 & 0.289 & 0.46429 & -0.40594 & 1.33451 \\
\hline 18 & Inappropriate out of seat behavioral & -0.028 & 0.977 & -0.0119 & -0.85257 & 0.82876 \\
\hline 19 & $\begin{array}{l}\text { Students do not complete science assignments } \\
\text { on time }\end{array}$ & 1.108 & 0.273 & 0.44048 & -0.35894 & 1.23989 \\
\hline 20 & $\begin{array}{l}\text { Lack of concern in performance of science } \\
\text { activities and homework }\end{array}$ & 1.177 & 0.245 & 0.45238 & -0.32113 & 1.22589 \\
\hline
\end{tabular}

\section{New Science Teacher Teaching Experience}

With regard to science teacher first three years of professional experiences, the calculations of mean and standard deviations of the level of behavioral challenges are displayed in Table 16.

Table 16: Means and standard deviations of science classroom behavioral challenges by teaching experience

\begin{tabular}{|c|c|c|c|c|}
\hline $\mathbf{N}$ & Challenges & Experience & Mean & $\begin{array}{l}\text { Standard } \\
\text { Deviation }\end{array}$ \\
\hline \multirow{3}{*}{1} & \multirow{3}{*}{ Students do not appear ready to learn science } & First-year & 2.5 & 1.30931 \\
\hline & & Second-year & 1.778 & 1.09291 \\
\hline & & Third-year & 2.188 & 1.09065 \\
\hline \multirow{3}{*}{2} & \multirow{3}{*}{$\begin{array}{l}\text { Students have negative ideas about science } \\
\text { lessons }\end{array}$} & First-year & 2.375 & 1.59799 \\
\hline & & Second-year & 2.556 & 1.13039 \\
\hline & & Third-year & 2.25 & 1.19137 \\
\hline \multirow{3}{*}{3} & \multirow{3}{*}{ Indifference to science lessons } & First-year & 2.375 & 1.06066 \\
\hline & & Second-year & 1.889 & 1.2693 \\
\hline & & Third-year & 2.188 & 1.17604 \\
\hline \multirow{3}{*}{4} & \multirow{3}{*}{ Students do not have correct supplies ready } & First-year & 2.375 & 1.06066 \\
\hline & & Second-year & 2.222 & 1.20185 \\
\hline & & Third-year & 2.313 & 1.20315 \\
\hline \multirow{3}{*}{5} & \multirow{3}{*}{$\begin{array}{l}\text { Students ignore the teacher instructions, orders } \\
\text { and their comments }\end{array}$} & First-year & 3 & 1.30931 \\
\hline & & Second-year & 2.667 & 1.32288 \\
\hline & & Third-year & 2.344 & 1.31024 \\
\hline \multirow[b]{2}{*}{6} & \multirow{2}{*}{ Lack of motivation to learn science } & First-year & 2.875 & 1.3562 \\
\hline & & Second-year & 3 & 1.11803 \\
\hline
\end{tabular}




\begin{tabular}{|c|c|c|c|c|}
\hline $\mathbf{N}$ & Challenges & Experience & Mean & $\begin{array}{l}\text { Standard } \\
\text { Deviation }\end{array}$ \\
\hline & & Third-year & 2.063 & 1.16224 \\
\hline \multirow{3}{*}{7} & \multirow{3}{*}{$\begin{array}{l}\text { Nonparticipation in classroom science } \\
\text { activities and labs }\end{array}$} & First-year & 2.625 & 1.40789 \\
\hline & & Second-year & 2.778 & 1.39443 \\
\hline & & Third-year & 2.375 & 1.3137 \\
\hline \multirow{3}{*}{8} & \multirow{3}{*}{$\begin{array}{l}\text { Attempts of cheating during tests or } \\
\text { examinations }\end{array}$} & First-year & 2.625 & 1.50594 \\
\hline & & Second-year & 2.222 & 1.48137 \\
\hline & & Third-year & 2.375 & 1.38541 \\
\hline \multirow{3}{*}{9} & \multirow{3}{*}{$\begin{array}{l}\text { Students are chatting among themselves } \\
\text { during science class }\end{array}$} & First-year & 2.75 & 1.16496 \\
\hline & & Second-year & 2.444 & 1.424 \\
\hline & & Third-year & 2.438 & 1.45774 \\
\hline \multirow{3}{*}{10} & \multirow{3}{*}{ Students interrupt others } & First-year & 3.25 & 1.28174 \\
\hline & & Second-year & 2.778 & 1.39443 \\
\hline & & Third-year & 2.375 & 1.3137 \\
\hline \multirow{3}{*}{11} & \multirow{3}{*}{ Excessive absences } & First-year & 1.5 & 0.75593 \\
\hline & & Second-year & 2.333 & 1.22474 \\
\hline & & Third-year & 1.656 & 1.09572 \\
\hline \multirow{3}{*}{12} & \multirow{3}{*}{ Students come late to science lessons } & First-year & 2.5 & 1.19523 \\
\hline & & Second-year & 3 & 1.11803 \\
\hline & & Third-year & 2.281 & 1.32554 \\
\hline \multirow{3}{*}{13} & \multirow{3}{*}{ Sleeping during science lessons } & First-year & 2.875 & 1.24642 \\
\hline & & Second-year & 3.333 & 1 \\
\hline & & Third-year & 2.938 & 1.50134 \\
\hline \multirow{3}{*}{14} & \multirow{3}{*}{ Leaving class early } & First-year & 3.25 & 1.58114 \\
\hline & & Second-year & 3.222 & 1.39443 \\
\hline & & Third-year & 3.25 & 1.41421 \\
\hline \multirow{3}{*}{15} & \multirow{3}{*}{$\begin{array}{l}\text { Playing and using mobile phones during } \\
\text { science class }\end{array}$} & First-year & 3.375 & 1.30247 \\
\hline & & Second-year & 3.778 & 1.39443 \\
\hline & & Third-year & 3.5 & 1.64611 \\
\hline \multirow{3}{*}{16} & \multirow{3}{*}{$\begin{array}{l}\text { Students reply to the teacher in the impolite } \\
\text { manner }\end{array}$} & First-year & 3.625 & 1.30247 \\
\hline & & Second-year & 3.444 & 1.74005 \\
\hline & & Third-year & 3.125 & 1.66074 \\
\hline \multirow{3}{*}{17} & \multirow{3}{*}{ Harassment and abuse of other students } & First-year & 3.5 & 1.51186 \\
\hline & & Second-year & 3.889 & 1.16667 \\
\hline & & Third-year & 3.469 & 1.60612 \\
\hline
\end{tabular}




\begin{tabular}{|r|l|l|r|r|}
\hline $\mathbf{N}$ & Challenges & Experience & Mean & $\begin{array}{l}\text { Standard } \\
\text { Deviation }\end{array}$ \\
\hline \multirow{2}{*}{18} & \multirow{2}{*}{ Inappropriate out of seat behavioral } & First-year & 3 & 1.51186 \\
\cline { 3 - 5 } & & Second-year & 3 & 1.32288 \\
\cline { 3 - 5 } & Third-year & 2.844 & 1.48344 \\
\hline \multirow{2}{*}{19} & \multirow{2}{*}{$\begin{array}{l}\text { Students do not complete science assignments } \\
\text { on time }\end{array}$} & First-year & 2.75 & 1.48805 \\
\cline { 3 - 5 } & & Second-year & 3.222 & 1.48137 \\
\cline { 3 - 5 } 20 & \multirow{2}{*}{$\begin{array}{l}\text { Lack of concern in performance of science } \\
\text { activities and homework }\end{array}$} & First-year & 2.438 & 1.3183 \\
\cline { 3 - 5 } & & Second-year & 2.5 & 1.19523 \\
\cline { 3 - 5 } & Third-year & 2.375 & 1.5899 \\
\hline
\end{tabular}

The top four challenges for first-year science teachers were: excessive absences $($ mean $=1.5)$, negative ideas about science $($ mean $=2.375)$, student indifference to science lessons $($ mean $=2.735)$ and inappropriate school supplies $($ mean $=2.735)$. Like first-year science teachers, third-year science teachers perceived student excessive absences (mean $=1.656)$ as the most important classroom challenge followed by lack of motivation to learn science $($ mean $=2.063)$, lack of readiness to learn science $($ mean $=2.188)$ and student indifference to science lessons ( $m e a n=2.188)$. Lack of readiness to learn science $($ mean $=1.778)$, student indifference to science lessons $($ mean $=1.889)$ and inappropriate school supplies (mean $=2.222$ ) are the top three most important behavioral challenges faced by secondyear science teachers.

Table 17 exhibits the results of one-way ANOVA for the level of behavioral challenges encountered by the first, second and third year science teachers in their classrooms. No significant differences in the level of classroom behavioral challenges were found among first, second and third year science teachers. 
Table 17: ANOVA results on science classroom behavioral challenges and teaching experience

\begin{tabular}{|c|c|c|c|c|c|c|c|}
\hline & & ANOVA & & & & & \\
\hline $\mathbf{N}$ & Challenges & & \begin{tabular}{|l} 
Sum of \\
Squares
\end{tabular} & df & $\begin{array}{l}\text { Mean } \\
\text { Square }\end{array}$ & $\mathbf{F}$ & $\begin{array}{l}\text { P- } \\
\text { value }\end{array}$ \\
\hline \multirow{3}{*}{1} & \multirow{3}{*}{$\begin{array}{l}\text { Students do not appear ready to } \\
\text { learn science }\end{array}$} & $\begin{array}{l}\text { Between } \\
\text { Groups }\end{array}$ & 2.263 & 2 & 1.132 & 0.89 & 0.417 \\
\hline & & $\begin{array}{l}\text { Within } \\
\text { Groups }\end{array}$ & 58.431 & 46 & 1.27 & & \\
\hline & & Total & 60.694 & 48 & & & \\
\hline \multirow{3}{*}{2} & \multirow{3}{*}{$\begin{array}{l}\text { Students have negative ideas about } \\
\text { science lessons }\end{array}$} & $\begin{array}{l}\text { Between } \\
\text { Groups }\end{array}$ & 0.678 & 2 & 0.339 & 0.22 & 0.806 \\
\hline & & $\begin{array}{l}\text { Within } \\
\text { Groups }\end{array}$ & 72.097 & 46 & 1.567 & & \\
\hline & & Total & 72.776 & 48 & & & \\
\hline \multirow{3}{*}{3} & \multirow{3}{*}{ Indifference to science lessons } & $\begin{array}{l}\text { Between } \\
\text { Groups }\end{array}$ & 1.055 & 2 & 0.527 & 0.38 & 0.685 \\
\hline & & $\begin{array}{l}\text { Within } \\
\text { Groups }\end{array}$ & 63.639 & 46 & 1.383 & & \\
\hline & & Total & 64.694 & 48 & & & \\
\hline \multirow{3}{*}{4} & \multirow{3}{*}{$\begin{array}{l}\text { Students do not have correct } \\
\text { supplies ready }\end{array}$} & $\begin{array}{l}\text { Between } \\
\text { Groups }\end{array}$ & 0.103 & 2 & 0.051 & 0.04 & 0.964 \\
\hline & & $\begin{array}{l}\text { Within } \\
\text { Groups }\end{array}$ & 64.306 & 46 & 1.398 & & \\
\hline & & Total & 64.408 & 48 & & & \\
\hline \multirow{3}{*}{5} & \multirow{3}{*}{$\begin{array}{l}\text { Students ignore the teacher } \\
\text { instructions, orders and their } \\
\text { comments }\end{array}$} & $\begin{array}{l}\text { Between } \\
\text { Groups }\end{array}$ & 3.026 & 2 & 1.513 & 0.88 & 0.422 \\
\hline & & $\begin{array}{l}\text { Within } \\
\text { Groups }\end{array}$ & 79.219 & 46 & 1.722 & & \\
\hline & & Total & 82.245 & 48 & & & \\
\hline \multirow{3}{*}{6} & \multirow{3}{*}{ Lack of motivation to learn science } & $\begin{array}{l}\text { Between } \\
\text { Groups } \\
\end{array}$ & 8.638 & 2 & 4.319 & 3.07 & 0.056 \\
\hline & & $\begin{array}{l}\text { Within } \\
\text { Groups }\end{array}$ & 64.75 & 46 & 1.408 & & \\
\hline & & Total & 73.388 & 48 & & & \\
\hline 7 & $\begin{array}{l}\text { Nonparticipation in classroom } \\
\text { science activities and labs }\end{array}$ & $\begin{array}{l}\text { Between } \\
\text { Groups }\end{array}$ & 1.314 & 2 & 0.657 & 0.37 & 0.697 \\
\hline
\end{tabular}




\begin{tabular}{|c|c|c|c|c|c|c|c|}
\hline \multirow[b]{2}{*}{$\mathbf{N}$} & \multirow[b]{2}{*}{ Challenges } & \multicolumn{6}{|l|}{ ANOVA } \\
\hline & & & \begin{tabular}{|l|}
$\begin{array}{l}\text { Sum of } \\
\text { Squares }\end{array}$ \\
\end{tabular} & df & $\begin{array}{l}\text { Mean } \\
\text { Square }\end{array}$ & $\mathbf{F}$ & $\begin{array}{l}\text { P- } \\
\text { value }\end{array}$ \\
\hline & & $\begin{array}{l}\text { Within } \\
\text { Groups }\end{array}$ & 82.931 & 46 & 1.803 & & \\
\hline & & Total & 84.245 & 48 & & & \\
\hline \multirow{3}{*}{8} & \multirow{3}{*}{$\begin{array}{l}\text { Attempts of cheating during tests or } \\
\text { examinations }\end{array}$} & $\begin{array}{l}\text { Between } \\
\text { Groups }\end{array}$ & 0.702 & 2 & 0.351 & 0.17 & 0.841 \\
\hline & & $\begin{array}{l}\text { Within } \\
\text { Groups }\end{array}$ & 92.931 & 46 & 2.02 & & \\
\hline & & Total & 93.633 & 48 & & & \\
\hline \multirow{3}{*}{9} & \multirow{3}{*}{$\begin{array}{l}\text { Students are chatting among } \\
\text { themselves during science class }\end{array}$} & $\begin{array}{l}\text { Between } \\
\text { Groups }\end{array}$ & 0.648 & 2 & 0.324 & 0.16 & 0.85 \\
\hline & & $\begin{array}{l}\text { Within } \\
\text { Groups }\end{array}$ & 91.597 & 46 & 1.991 & & \\
\hline & & Total & 92.245 & 48 & & & \\
\hline \multirow{3}{*}{10} & \multirow{3}{*}{ Students interrupt others } & $\begin{array}{l}\text { Between } \\
\text { Groups }\end{array}$ & 5.281 & 2 & 2.641 & 1.51 & 0.232 \\
\hline & & $\begin{array}{l}\text { Within } \\
\text { Groups }\end{array}$ & 80.556 & 46 & 1.751 & & \\
\hline & & Total & 85.837 & 48 & & & \\
\hline \multirow{3}{*}{11} & \multirow{3}{*}{ Excessive absences } & $\begin{array}{l}\text { Between } \\
\text { Groups }\end{array}$ & 3.842 & 2 & 1.921 & 1.66 & 0.201 \\
\hline & & $\begin{array}{l}\text { Within } \\
\text { Groups }\end{array}$ & 53.219 & 46 & 1.157 & & \\
\hline & & Total & 57.061 & 48 & & & \\
\hline \multirow{3}{*}{12} & \multirow{3}{*}{$\begin{array}{l}\text { Students come late to science } \\
\text { lessons }\end{array}$} & $\begin{array}{l}\text { Between } \\
\text { Groups }\end{array}$ & 3.654 & 2 & 1.827 & 1.13 & 0.332 \\
\hline & & $\begin{array}{l}\text { Within } \\
\text { Groups }\end{array}$ & 74.469 & 46 & 1.619 & & \\
\hline & & Total & 78.122 & 48 & & & \\
\hline \multirow{3}{*}{13} & \multirow{3}{*}{ Sleeping during science lessons } & $\begin{array}{l}\text { Between } \\
\text { Groups } \\
\end{array}$ & 1.25 & 2 & 0.625 & 0.32 & 0.725 \\
\hline & & $\begin{array}{l}\text { Within } \\
\text { Groups }\end{array}$ & 88.75 & 46 & 1.929 & & \\
\hline & & Total & 90 & 48 & & & \\
\hline 14 & Leaving class early & $\begin{array}{l}\text { Between } \\
\text { Groups }\end{array}$ & 0.006 & 2 & 0.003 & 0 & 0.999 \\
\hline
\end{tabular}




\begin{tabular}{|c|c|c|c|c|c|c|c|}
\hline \multirow[b]{2}{*}{$\mathbf{N}$} & \multirow[b]{2}{*}{ Challenges } & \multicolumn{6}{|l|}{ ANOVA } \\
\hline & & & \begin{tabular}{|l|l} 
Sum of \\
Squares
\end{tabular} & df & $\begin{array}{l}\text { Mean } \\
\text { Square }\end{array}$ & $\mathbf{F}$ & $\begin{array}{l}\text { P- } \\
\text { value }\end{array}$ \\
\hline & & $\begin{array}{l}\text { Within } \\
\text { Groups }\end{array}$ & 95.056 & 46 & 2.066 & & \\
\hline & & Total & 95.061 & 48 & & & \\
\hline \multirow{3}{*}{15} & \multirow{3}{*}{$\begin{array}{l}\text { Playing and using mobile phones } \\
\text { during science class }\end{array}$} & $\begin{array}{l}\text { Between } \\
\text { Groups }\end{array}$ & 0.774 & 2 & 0.387 & 0.16 & 0.853 \\
\hline & & $\begin{array}{l}\text { Within } \\
\text { Groups }\end{array}$ & 111.431 & 46 & 2.422 & & \\
\hline & & Total & 112.204 & 48 & & & \\
\hline \multirow{3}{*}{16} & \multirow{3}{*}{$\begin{array}{l}\text { Students reply to the teacher in the } \\
\text { impolite manner }\end{array}$} & $\begin{array}{l}\text { Between } \\
\text { Groups }\end{array}$ & 1.954 & 2 & 0.977 & 0.37 & 0.693 \\
\hline & & $\begin{array}{l}\text { Within } \\
\text { Groups }\end{array}$ & 121.597 & 46 & 2.643 & & \\
\hline & & Total & 123.551 & 48 & & & \\
\hline \multirow{3}{*}{17} & \multirow{3}{*}{$\begin{array}{l}\text { Harassment and abuse of other } \\
\text { students }\end{array}$} & $\begin{array}{l}\text { Between } \\
\text { Groups } \\
\end{array}$ & 1.265 & 2 & 0.632 & 0.27 & 0.763 \\
\hline & & $\begin{array}{l}\text { Within } \\
\text { Groups }\end{array}$ & 106.858 & 46 & 2.323 & & \\
\hline & & Total & 108.122 & 48 & & & \\
\hline \multirow{3}{*}{18} & \multirow{3}{*}{ Inappropriate out of seat behavioral } & $\begin{array}{l}\text { Between } \\
\text { Groups }\end{array}$ & 0.271 & 2 & 0.136 & 0.06 & 0.939 \\
\hline & & $\begin{array}{l}\text { Within } \\
\text { Groups }\end{array}$ & 98.219 & 46 & 2.135 & & \\
\hline & & Total & 98.49 & 48 & & & \\
\hline \multirow{3}{*}{19} & \multirow{3}{*}{$\begin{array}{l}\text { Students do not complete science } \\
\text { assignments on time }\end{array}$} & $\begin{array}{l}\text { Between } \\
\text { Groups }\end{array}$ & 4.457 & 2 & 2.229 & 1.18 & 0.317 \\
\hline & & $\begin{array}{l}\text { Within } \\
\text { Groups }\end{array}$ & 86.931 & 46 & 1.89 & & \\
\hline & & Total & 91.388 & 48 & & & \\
\hline \multirow[t]{3}{*}{20} & \multirow{3}{*}{$\begin{array}{l}\text { Lack of concern in performance of } \\
\text { science activities and homework }\end{array}$} & $\begin{array}{l}\text { Between } \\
\text { Groups } \\
\end{array}$ & 8.115 & 2 & 4.057 & 2.4 & 0.102 \\
\hline & & $\begin{array}{l}\text { Within } \\
\text { Groups }\end{array}$ & 77.722 & 46 & 1.69 & & \\
\hline & & Total & 85.837 & 48 & & & \\
\hline
\end{tabular}




\section{New Science Teacher School Level (Elementary, Middle and High schools)}

Table 18 shows the descriptive statistics of mean and standard deviation for the effect of school level of new science teachers on behavioral challenges. Elementary and high school science teachers gave the highest challenge rankings to excessive school absences with mean $=2.8333$ and mean $=1.6154$ respectively. Middle school science teachers ranked excessive school absences $($ mean $=1.5882)$ in the third place of their challenges preceding by challenges related to student lack of readiness to learn science $($ mean $=1.5294)$ and cheating attempts $($ mean $=1.5294)$ during tests or examinations. A further three challenges are featured in the top four challenges faced by high school science teachers: student indifference to science lessons $($ mean $=2.2308)$, lack of readiness to learn science $($ mean $=2.3077)$ and inappropriate school supplies $($ mean $=2.3077)$. Students lack of motivation to learn science $($ mean $=3)$, unwillingness to participate in classroom activities $($ mean $=3.1667)$ and turning the assignments in after deadline $($ mean $=3.1667)$ are major behavioral challenges encountered by elementary school teachers in their classrooms.

Table 18: Means and standard deviations of science classroom behavioral challenges by school level

\begin{tabular}{|r|l|l|l|r|}
\hline $\mathbf{N}$ & Challenges & School Level & Mean & $\begin{array}{l}\text { Standard } \\
\text { Deviation }\end{array}$ \\
\hline \multirow{2}{*}{1} & \multirow{2}{*}{$\begin{array}{l}\text { Students do not appear ready to learn } \\
\text { science }\end{array}$} & Elementary school & 3.3333 & 1.0328 \\
\cline { 3 - 5 } & & Middle School & 1.5294 & 0.79982 \\
\cline { 3 - 5 } & & High school & 2.3077 & 1.08699 \\
\hline \multirow{2}{*}{2} & \multirow{2}{*}{$\begin{array}{l}\text { Students have negative ideas about } \\
\text { science lessons }\end{array}$} & Elementary school & 3.6667 & 1.0328 \\
\cline { 3 - 5 } & & Middle School & 1.7059 & 0.77174 \\
\cline { 3 - 5 } & & High school & 2.4231 & 1.27037 \\
\hline \multirow{2}{*}{3} & \multirow{3}{*}{\begin{tabular}{l} 
Indifference to science lessons \\
\cline { 3 - 5 }
\end{tabular}} & Elementary school & 3.3333 & 1.21106 \\
\cline { 3 - 5 } & Middle School & 1.6471 & 0.86177 \\
\cline { 3 - 5 } & High school & 2.2308 & 1.1422 \\
\hline
\end{tabular}




\begin{tabular}{|c|c|c|c|c|}
\hline $\mathbf{N}$ & Challenges & School Level & Mean & $\begin{array}{l}\text { Standard } \\
\text { Deviation }\end{array}$ \\
\hline \multirow{3}{*}{4} & \multirow{3}{*}{$\begin{array}{l}\text { Students do not have correct supplies } \\
\text { ready }\end{array}$} & Elementary school & 4 & 1.09545 \\
\hline & & Middle School & 1.7059 & 0.77174 \\
\hline & & High school & 2.3077 & 1.01071 \\
\hline \multirow{3}{*}{5} & \multirow{3}{*}{$\begin{array}{l}\text { Students ignore the teacher instructions, } \\
\text { orders and their comments }\end{array}$} & Elementary school & 3.8333 & 0.75277 \\
\hline & & Middle School & 1.8824 & 1.21873 \\
\hline & & High school & 2.6154 & 1.23538 \\
\hline \multirow{3}{*}{6} & \multirow{3}{*}{ Lack of motivation to learn science } & Elementary school & 3 & 1.41421 \\
\hline & & Middle School & 1.7647 & 1.09141 \\
\hline & & High school & 2.6154 & 1.16883 \\
\hline \multirow{3}{*}{7} & \multirow{3}{*}{$\begin{array}{l}\text { Nonparticipation in classroom science } \\
\text { activities and labs }\end{array}$} & Elementary school & 3.1667 & 1.32916 \\
\hline & & Middle School & 1.7059 & 1.15999 \\
\hline & & High school & 2.8462 & 1.22286 \\
\hline \multirow{3}{*}{8} & \multirow{3}{*}{$\begin{array}{l}\text { Attempts of cheating during tests or } \\
\text { examinations }\end{array}$} & Elementary school & 4 & 0.63246 \\
\hline & & Middle School & 1.5294 & 0.94324 \\
\hline & & High school & 2.5769 & 1.39063 \\
\hline \multirow{3}{*}{9} & \multirow{3}{*}{$\begin{array}{l}\text { Students are chatting among themselves } \\
\text { during science class }\end{array}$} & Elementary school & 3.6667 & 1.0328 \\
\hline & & Middle School & 1.8235 & 1.18508 \\
\hline & & High school & 2.6538 & 1.38397 \\
\hline \multirow{3}{*}{10} & \multirow{3}{*}{ Students interrupt others } & Elementary school & 3.6667 & 1.0328 \\
\hline & & Middle School & 2 & 1.22474 \\
\hline & & High school & 2.7308 & 1.31325 \\
\hline \multirow{3}{*}{11} & \multirow{3}{*}{ Excessive absences } & Elementary school & 2.8333 & 1.16905 \\
\hline & & Middle School & 1.5882 & 1.00367 \\
\hline & & High school & 1.6154 & 1.02282 \\
\hline \multirow{3}{*}{12} & \multirow{3}{*}{ Students come late to science lessons } & Elementary school & 3.6667 & 0.5164 \\
\hline & & Middle School & 1.9412 & 1.34493 \\
\hline & & High school & 2.5 & 1.17473 \\
\hline \multirow{3}{*}{13} & \multirow{3}{*}{ Sleeping during science lessons } & Elementary school & 4.3333 & 0.5164 \\
\hline & & Middle School & 2 & 1.1726 \\
\hline & & High school & 3.3462 & 1.19808 \\
\hline \multirow{3}{*}{14} & \multirow{3}{*}{ Leaving class early } & Elementary school & 4.3333 & 0.5164 \\
\hline & & Middle School & 2.5294 & 1.4194 \\
\hline & & High school & 3.4615 & 1.33359 \\
\hline \multirow[b]{2}{*}{15} & \multirow{2}{*}{$\begin{array}{l}\text { Playing and using mobile phones during } \\
\text { science class }\end{array}$} & Elementary school & 4.8333 & 0.40825 \\
\hline & & Middle School & 2.5882 & 1.54349 \\
\hline
\end{tabular}




\begin{tabular}{|c|c|c|c|c|}
\hline $\mathbf{N}$ & Challenges & School Level & Mean & $\begin{array}{l}\text { Standard } \\
\text { Deviation }\end{array}$ \\
\hline & & High school & 3.8462 & 1.34736 \\
\hline \multirow{3}{*}{16} & \multirow{3}{*}{$\begin{array}{l}\text { Students reply to the teacher in the } \\
\text { impolite manner }\end{array}$} & Elementary school & 4.1667 & 1.32916 \\
\hline & & Middle School & 2.4706 & 1.54587 \\
\hline & & High school & 3.5769 & 1.52769 \\
\hline \multirow{3}{*}{17} & \multirow{3}{*}{ Harassment and abuse of other students } & Elementary school & 4.3333 & 1.0328 \\
\hline & & Middle School & 2.4706 & 1.46277 \\
\hline & & High school & 4.0769 & 1.23038 \\
\hline \multirow{3}{*}{18} & \multirow{3}{*}{ Inappropriate out of seat behavioral } & Elementary school & 4 & 0.89443 \\
\hline & & Middle School & 2.0588 & 1.14404 \\
\hline & & High school & 3.1923 & 1.44275 \\
\hline \multirow{3}{*}{19} & \multirow{3}{*}{$\begin{array}{l}\text { Students do not complete science } \\
\text { assignments on time }\end{array}$} & Elementary school & 3.1667 & 0.75277 \\
\hline & & Middle School & 2.0588 & 1.08804 \\
\hline & & High school & 2.8846 & 1.55761 \\
\hline \multirow{3}{*}{20} & \multirow{3}{*}{$\begin{array}{l}\text { Lack of concern in performance of } \\
\text { science activities and homework }\end{array}$} & Elementary school & 3.5 & 0.54772 \\
\hline & & Middle School & 2.0588 & 1.08804 \\
\hline & & High school & 2.7308 & 1.48479 \\
\hline
\end{tabular}

A one-way ANOVA was used to compare the behavioral challenges faced by elementary, middle and high school new science teachers. The ANOVA results are displayed in Table 19.

Table 19: ANOVA results on science classroom behavioral challenges and teacher school levels

\begin{tabular}{|c|c|c|c|c|c|c|c|}
\hline & & ANOVA & & & & & \\
\hline $\mathbf{N}$ & Challenges & & $\begin{array}{l}\text { Sum of } \\
\text { Squares }\end{array}$ & df & $\begin{array}{l}\text { Mean } \\
\text { Square }\end{array}$ & $\mathbf{F}$ & $\begin{array}{l}\text { P- } \\
\text { Value }\end{array}$ \\
\hline \multirow{3}{*}{1} & \multirow{3}{*}{$\begin{array}{l}\text { Students do not appear ready to } \\
\text { learn science }\end{array}$} & $\begin{array}{l}\text { Between } \\
\text { Groups }\end{array}$ & 15.587 & 2 & 7.793 & 7.948 & 0.001 \\
\hline & & $\begin{array}{l}\text { Within } \\
\text { Groups }\end{array}$ & 45.107 & 46 & 0.981 & & \\
\hline & & Total & 60.694 & 48 & & & \\
\hline \multirow[t]{3}{*}{2} & \multirow{3}{*}{$\begin{array}{l}\text { Students have negative ideas } \\
\text { about science lessons }\end{array}$} & $\begin{array}{l}\text { Between } \\
\text { Groups }\end{array}$ & 17.567 & 2 & 8.783 & 7.318 & 0.002 \\
\hline & & $\begin{array}{l}\text { Within } \\
\text { Groups }\end{array}$ & 55.209 & 46 & 1.2 & & \\
\hline & & Total & 72.776 & 48 & & & \\
\hline
\end{tabular}




\begin{tabular}{|c|c|c|c|c|c|c|c|}
\hline \multirow[b]{2}{*}{$\mathbf{N}$} & \multirow[b]{2}{*}{ Challenges } & \multicolumn{6}{|l|}{ ANOVA } \\
\hline & & & $\begin{array}{l}\text { Sum of } \\
\text { Squares }\end{array}$ & df & $\begin{array}{l}\text { Mean } \\
\text { Square }\end{array}$ & $\mathbf{F}$ & $\begin{array}{l}\text { P- } \\
\text { Value }\end{array}$ \\
\hline \multirow{3}{*}{3} & \multirow{3}{*}{ Indifference to science lessons } & $\begin{array}{l}\text { Between } \\
\text { Groups }\end{array}$ & 12.863 & 2 & 6.431 & 5.708 & 0.006 \\
\hline & & $\begin{array}{l}\text { Within } \\
\text { Groups }\end{array}$ & 51.831 & 46 & 1.127 & & \\
\hline & & Total & 64.694 & 48 & & & \\
\hline \multirow{3}{*}{4} & \multirow{3}{*}{$\begin{array}{l}\text { Students do not have correct } \\
\text { supplies ready }\end{array}$} & $\begin{array}{l}\text { Between } \\
\text { Groups }\end{array}$ & 23.34 & 2 & 11.67 & 13.072 & 0 \\
\hline & & $\begin{array}{l}\text { Within } \\
\text { Groups }\end{array}$ & 41.068 & 46 & 0.893 & & \\
\hline & & Total & 64.408 & 48 & & & \\
\hline \multirow[t]{3}{*}{5} & \multirow{3}{*}{$\begin{array}{l}\text { Students ignore the teacher } \\
\text { instructions, orders and their } \\
\text { comments }\end{array}$} & $\begin{array}{l}\text { Between } \\
\text { Groups }\end{array}$ & 17.493 & 2 & 8.747 & 6.214 & 0.004 \\
\hline & & $\begin{array}{l}\text { Within } \\
\text { Groups }\end{array}$ & 64.752 & 46 & 1.408 & & \\
\hline & & Total & 82.245 & 48 & & & \\
\hline \multirow{3}{*}{6} & \multirow{3}{*}{$\begin{array}{l}\text { Lack of motivation to learn } \\
\text { science }\end{array}$} & $\begin{array}{l}\text { Between } \\
\text { Groups }\end{array}$ & 10.175 & 2 & 5.088 & 3.702 & 0.032 \\
\hline & & $\begin{array}{l}\text { Within } \\
\text { Groups }\end{array}$ & 63.213 & 46 & 1.374 & & \\
\hline & & Total & 73.388 & 48 & & & \\
\hline \multirow{3}{*}{7} & \multirow{3}{*}{$\begin{array}{l}\text { Nonparticipation in classroom } \\
\text { science activities and labs }\end{array}$} & $\begin{array}{l}\text { Between } \\
\text { Groups }\end{array}$ & 16.498 & 2 & 8.249 & 5.601 & 0.007 \\
\hline & & $\begin{array}{l}\text { Within } \\
\text { Groups }\end{array}$ & 67.747 & 46 & 1.473 & & \\
\hline & & Total & 84.245 & 48 & & & \\
\hline \multirow{3}{*}{8} & \multirow{3}{*}{$\begin{array}{l}\text { Attempts of cheating during tests } \\
\text { or examinations }\end{array}$} & $\begin{array}{l}\text { Between } \\
\text { Groups }\end{array}$ & 29.051 & 2 & 14.526 & 10.346 & 0 \\
\hline & & $\begin{array}{l}\text { Within } \\
\text { Groups }\end{array}$ & 64.581 & 46 & 1.404 & & \\
\hline & & Total & 93.633 & 48 & & & \\
\hline \multirow{3}{*}{9} & \multirow{3}{*}{$\begin{array}{l}\text { Students are chatting among } \\
\text { themselves during science class }\end{array}$} & $\begin{array}{l}\text { Between } \\
\text { Groups }\end{array}$ & 16.556 & 2 & 8.278 & 5.031 & 0.011 \\
\hline & & $\begin{array}{l}\text { Within } \\
\text { Groups }\end{array}$ & 75.689 & 46 & 1.645 & & \\
\hline & & Total & 92.245 & 48 & & & \\
\hline
\end{tabular}




\begin{tabular}{|c|c|c|c|c|c|c|c|}
\hline \multirow[b]{2}{*}{$\mathbf{N}$} & \multirow[b]{2}{*}{ Challenges } & \multicolumn{6}{|l|}{ ANOVA } \\
\hline & & & $\begin{array}{l}\text { Sum of } \\
\text { Squares }\end{array}$ & df & $\begin{array}{l}\text { Mean } \\
\text { Square }\end{array}$ & $\mathbf{F}$ & $\begin{array}{l}\text { P- } \\
\text { Value }\end{array}$ \\
\hline \multirow{3}{*}{10} & \multirow{3}{*}{ Students interrupt others } & $\begin{array}{l}\text { Between } \\
\text { Groups }\end{array}$ & 13.388 & 2 & 6.694 & 4.25 & 0.02 \\
\hline & & $\begin{array}{l}\text { Within } \\
\text { Groups }\end{array}$ & 72.449 & 46 & 1.575 & & \\
\hline & & Total & 85.837 & 48 & & & \\
\hline \multirow{3}{*}{11} & \multirow{3}{*}{ Excessive absences } & $\begin{array}{l}\text { Between } \\
\text { Groups }\end{array}$ & 7.956 & 2 & 3.978 & 3.727 & 0.032 \\
\hline & & $\begin{array}{l}\text { Within } \\
\text { Groups }\end{array}$ & 49.105 & 46 & 1.067 & & \\
\hline & & Total & 57.061 & 48 & & & \\
\hline \multirow{3}{*}{12} & \multirow{3}{*}{$\begin{array}{l}\text { Students come late to science } \\
\text { lessons }\end{array}$} & $\begin{array}{l}\text { Between } \\
\text { Groups }\end{array}$ & 13.348 & 2 & 6.674 & 4.74 & 0.013 \\
\hline & & $\begin{array}{l}\text { Within } \\
\text { Groups }\end{array}$ & 64.775 & 46 & 1.408 & & \\
\hline & & Total & 78.122 & 48 & & & \\
\hline \multirow{3}{*}{13} & \multirow{3}{*}{ Sleeping during science lessons } & $\begin{array}{l}\text { Between } \\
\text { Groups }\end{array}$ & 30.782 & 2 & 15.391 & 11.956 & 0 \\
\hline & & $\begin{array}{l}\text { Within } \\
\text { Groups }\end{array}$ & 59.218 & 46 & 1.287 & & \\
\hline & & Total & 90 & 48 & & & \\
\hline \multirow{3}{*}{14} & \multirow{3}{*}{ Leaving class early } & $\begin{array}{l}\text { Between } \\
\text { Groups }\end{array}$ & 17.031 & 2 & 8.516 & 5.02 & 0.011 \\
\hline & & $\begin{array}{l}\text { Within } \\
\text { Groups }\end{array}$ & 78.03 & 46 & 1.696 & & \\
\hline & & Total & 95.061 & 48 & & & \\
\hline \multirow{3}{*}{15} & \multirow{3}{*}{$\begin{array}{l}\text { Playing and using mobile phones } \\
\text { during science class }\end{array}$} & $\begin{array}{l}\text { Between } \\
\text { Groups }\end{array}$ & 27.868 & 2 & 13.934 & 7.6 & 0.001 \\
\hline & & $\begin{array}{l}\text { Within } \\
\text { Groups }\end{array}$ & 84.336 & 46 & 1.833 & & \\
\hline & & Total & 112.204 & 48 & & & \\
\hline \multirow{3}{*}{16} & \multirow{3}{*}{$\begin{array}{l}\text { Students reply to the teacher in } \\
\text { the impolite manner }\end{array}$} & $\begin{array}{l}\text { Between } \\
\text { Groups }\end{array}$ & 18.136 & 2 & 9.068 & 3.957 & 0.026 \\
\hline & & $\begin{array}{l}\text { Within } \\
\text { Groups }\end{array}$ & 105.415 & 46 & 2.292 & & \\
\hline & & Total & 123.551 & 48 & & & \\
\hline
\end{tabular}




\begin{tabular}{|c|c|c|c|c|c|c|c|}
\hline & & ANOVA & & & & & \\
\hline $\mathbf{N}$ & Challenges & & $\begin{array}{l}\text { Sum of } \\
\text { Squares }\end{array}$ & df & $\begin{array}{l}\text { Mean } \\
\text { Square }\end{array}$ & $\mathbf{F}$ & $\begin{array}{l}\text { P- } \\
\text { Value }\end{array}$ \\
\hline \multirow{3}{*}{17} & \multirow{3}{*}{$\begin{array}{l}\text { Harassment and abuse of other } \\
\text { students }\end{array}$} & $\begin{array}{l}\text { Between } \\
\text { Groups }\end{array}$ & 30.708 & 2 & 15.354 & 9.123 & 0 \\
\hline & & $\begin{array}{l}\text { Within } \\
\text { Groups }\end{array}$ & 77.415 & 46 & 1.683 & & \\
\hline & & Total & 108.122 & 48 & & & \\
\hline \multirow{3}{*}{18} & \multirow{3}{*}{$\begin{array}{l}\text { Inappropriate out of seat } \\
\text { behavioral }\end{array}$} & $\begin{array}{l}\text { Between } \\
\text { Groups }\end{array}$ & 21.51 & 2 & 10.755 & 6.427 & 0.003 \\
\hline & & $\begin{array}{l}\text { Within } \\
\text { Groups }\end{array}$ & 76.98 & 46 & 1.673 & & \\
\hline & & Total & 98.49 & 48 & & & \\
\hline \multirow{3}{*}{19} & \multirow{3}{*}{$\begin{array}{l}\text { Students do not complete science } \\
\text { assignments on time }\end{array}$} & $\begin{array}{l}\text { Between } \\
\text { Groups }\end{array}$ & 8.959 & 2 & 4.48 & 2.5 & 0.093 \\
\hline & & $\begin{array}{l}\text { Within } \\
\text { Groups }\end{array}$ & 82.428 & 46 & 1.792 & & \\
\hline & & Total & 91.388 & 48 & & & \\
\hline \multirow[t]{3}{*}{20} & \multirow{3}{*}{$\begin{array}{l}\text { Lack of concern in performance } \\
\text { of science activities and } \\
\text { homework }\end{array}$} & $\begin{array}{l}\text { Between } \\
\text { Groups }\end{array}$ & 10.28 & 2 & 5.14 & 3.129 & 0.053 \\
\hline & & $\begin{array}{l}\text { Within } \\
\text { Groups }\end{array}$ & 75.557 & 46 & 1.643 & & \\
\hline & & Total & 85.837 & 48 & & & \\
\hline
\end{tabular}

Findings suggest that there are significant differences among elementary, middle and high school new science teachers for all the classroom challenges. All p-values were less than 0.05 significant. To investigate the cause of the differences of the level of classroom behavioral challenges among elementary, middle and high school new science teachers, multiple pairwise comparison procedures were used. The results of all pairwise comparisons are reported in Table 20 . 
Table 20: Multiple pairwise comparisons of science classroom behavioral challenges faced by elementary, middle and high school new science teachers

\begin{tabular}{|c|c|c|c|c|c|c|c|}
\hline \multirow{2}{*}{$\mathbf{N}$} & \multirow{2}{*}{\multicolumn{3}{|c|}{ Dependent Variable }} & \multirow{3}{*}{$\begin{array}{l}\begin{array}{l}\text { Mean } \\
\text { Differen } \\
\text { ce }(\mathbf{I}-J)\end{array} \\
.77828^{*}\end{array}$} & \multirow{3}{*}{$\begin{array}{r}\begin{array}{l}\text { P- } \\
\text { value }\end{array} \\
0.04\end{array}$} & \multicolumn{2}{|c|}{$\begin{array}{l}\text { 95\% Confidence } \\
\text { Interval }\end{array}$} \\
\hline & & & & & & Lower & Upper \\
\hline \multirow{6}{*}{1} & \multirow{6}{*}{$\begin{array}{l}\text { Students do not } \\
\text { appear ready to learn } \\
\text { science }\end{array}$} & \multirow{2}{*}{ High school } & $\begin{array}{l}\text { Middle } \\
\text { School }\end{array}$ & & & 0.0303 & 1.5263 \\
\hline & & & $\begin{array}{l}\text { Elementary } \\
\text { school }\end{array}$ & -1.0256 & 0.068 & -2.1118 & 0.0605 \\
\hline & & \multirow{2}{*}{ Middle School } & High school & $-.77828^{*}$ & 0.04 & -1.5263 & -0.0303 \\
\hline & & & $\begin{array}{l}\text { Elementary } \\
\text { school }\end{array}$ & $-1.80392^{*}$ & 0.001 & -2.9427 & -0.6651 \\
\hline & & \multirow{2}{*}{$\begin{array}{l}\text { Elementary } \\
\text { school }\end{array}$} & High school & 1.02564 & 0.068 & -0.0605 & 2.1118 \\
\hline & & & $\begin{array}{l}\text { Middle } \\
\text { School }\end{array}$ & $1.80392^{*}$ & 0.001 & 0.6651 & 2.9427 \\
\hline \multirow{6}{*}{2} & \multirow{6}{*}{$\begin{array}{l}\text { Students have } \\
\text { negative ideas about } \\
\text { science lessons }\end{array}$} & \multirow{2}{*}{ High school } & $\begin{array}{l}\text { Middle } \\
\text { School }\end{array}$ & 0.71719 & 0.101 & -0.1104 & 1.5447 \\
\hline & & & $\begin{array}{l}\text { Elementary } \\
\text { school }\end{array}$ & $-1.24359^{*}$ & 0.041 & -2.4453 & -0.0419 \\
\hline & & \multirow{2}{*}{ Middle School } & High school & -0.7172 & 0.101 & -1.5447 & 0.1104 \\
\hline & & & $\begin{array}{l}\text { Elementary } \\
\text { school }\end{array}$ & $-1.96078^{*}$ & 0.001 & -3.2207 & -0.7009 \\
\hline & & \multirow{2}{*}{$\begin{array}{l}\text { Elementary } \\
\text { school }\end{array}$} & High school & $1.24359^{*}$ & 0.041 & 0.0419 & 2.4453 \\
\hline & & & $\begin{array}{l}\text { Middle } \\
\text { School }\end{array}$ & $1.96078^{*}$ & 0.001 & 0.7009 & 3.2207 \\
\hline \multirow{4}{*}{3} & \multirow{4}{*}{$\begin{array}{l}\text { Indifference to } \\
\text { science lessons }\end{array}$} & \multirow{2}{*}{ High school } & $\begin{array}{l}\text { Middle } \\
\text { School }\end{array}$ & 0.58371 & 0.193 & -0.2181 & 1.3855 \\
\hline & & & $\begin{array}{l}\text { Elementary } \\
\text { school }\end{array}$ & -1.1026 & 0.067 & -2.2669 & 0.0618 \\
\hline & & \multirow{2}{*}{ Middle School } & High school & -0.5837 & 0.193 & -1.3855 & 0.2181 \\
\hline & & & $\begin{array}{l}\text { Elementary } \\
\text { school }\end{array}$ & $-1.68627^{*}$ & 0.005 & -2.907 & -0.4655 \\
\hline
\end{tabular}




\begin{tabular}{|c|c|c|c|c|c|c|c|}
\hline \multirow{4}{*}{$\mathbf{N}$} & \multirow{2}{*}{\multicolumn{3}{|c|}{ Dependent Variable }} & \multirow{2}{*}{$\begin{array}{l}\text { Mean } \\
\text { Differen } \\
\text { ce (I-J) }\end{array}$} & \multirow{2}{*}{$\begin{array}{l}P \text { - } \\
\text { value }\end{array}$} & \multicolumn{2}{|c|}{$\begin{array}{l}\text { 95\% Confidence } \\
\text { Interval }\end{array}$} \\
\hline & & & & & & $\begin{array}{l}\text { Lower } \\
\text { Bound }\end{array}$ & $\begin{array}{l}\text { Upper } \\
\text { Bound }\end{array}$ \\
\hline & & \multirow{2}{*}{$\begin{array}{l}\text { Elementary } \\
\text { school }\end{array}$} & High school & 1.10256 & 0.067 & -0.0618 & 2.2669 \\
\hline & & & $\begin{array}{l}\text { Middle } \\
\text { School }\end{array}$ & $1.68627^{*}$ & 0.005 & 0.4655 & 2.907 \\
\hline \multirow{6}{*}{4} & \multirow{6}{*}{$\begin{array}{l}\text { Students do not have } \\
\text { correct supplies } \\
\text { ready }\end{array}$} & \multirow{2}{*}{ High school } & $\begin{array}{l}\text { Middle } \\
\text { School }\end{array}$ & 0.60181 & 0.114 & -0.1119 & 1.3155 \\
\hline & & & $\begin{array}{l}\text { Elementary } \\
\text { school }\end{array}$ & $-1.69231^{*}$ & 0.001 & -2.7287 & -0.6559 \\
\hline & & \multirow{2}{*}{ Middle School } & High school & -0.6018 & 0.114 & -1.3155 & 0.1119 \\
\hline & & & $\begin{array}{l}\text { Elementary } \\
\text { school }\end{array}$ & $-2.29412^{*}$ & 0 & -3.3807 & -1.2075 \\
\hline & & \multirow{2}{*}{$\begin{array}{l}\text { Elementary } \\
\text { school }\end{array}$} & High school & $1.69231^{*}$ & 0.001 & 0.6559 & 2.7287 \\
\hline & & & $\begin{array}{l}\text { Middle } \\
\text { School }\end{array}$ & $2.29412^{*}$ & 0 & 1.2075 & 3.3807 \\
\hline \multirow{6}{*}{5} & \multirow{6}{*}{$\begin{array}{l}\text { Students ignore the } \\
\text { teacher instructions, } \\
\text { orders and their } \\
\text { comments }\end{array}$} & \multirow{2}{*}{ High school } & $\begin{array}{l}\text { Middle } \\
\text { School }\end{array}$ & 0.73303 & 0.128 & -0.1632 & 1.6292 \\
\hline & & & $\begin{array}{l}\text { Elementary } \\
\text { school }\end{array}$ & -1.218 & 0.071 & -2.5193 & 0.0834 \\
\hline & & \multirow{2}{*}{ Middle School } & High school & -0.733 & 0.128 & -1.6292 & 0.1632 \\
\hline & & & $\begin{array}{l}\text { Elementary } \\
\text { school }\end{array}$ & $-1.95098^{*}$ & 0.003 & -3.3154 & -0.5865 \\
\hline & & \multirow{2}{*}{$\begin{array}{l}\text { Elementary } \\
\text { school }\end{array}$} & High school & 1.21795 & 0.071 & -0.0834 & 2.5193 \\
\hline & & & $\begin{array}{l}\text { Middle } \\
\text { School }\end{array}$ & $1.95098^{*}$ & 0.003 & 0.5865 & 3.3154 \\
\hline \multirow{3}{*}{6} & \multirow{3}{*}{$\begin{array}{l}\text { Lack of motivation } \\
\text { to learn science }\end{array}$} & \multirow{2}{*}{ High school } & $\begin{array}{l}\text { Middle } \\
\text { School }\end{array}$ & 0.85068 & 0.062 & -0.0348 & 1.7362 \\
\hline & & & $\begin{array}{l}\text { Elementary } \\
\text { school }\end{array}$ & -0.3846 & 0.75 & -1.6704 & 0.9012 \\
\hline & & Middle School & High school & -0.8507 & 0.062 & -1.7362 & 0.0348 \\
\hline
\end{tabular}




\begin{tabular}{|c|c|c|c|c|c|c|c|}
\hline \multirow{5}{*}{$\mathbf{N}$} & \multirow{5}{*}{ Dependent Variable } & & & \multirow{2}{*}{$\begin{array}{l}\text { Mean } \\
\text { Differen } \\
\text { ce (I-J) }\end{array}$} & \multirow{2}{*}{$\begin{array}{l}P \text { - } \\
\text { value }\end{array}$} & \multicolumn{2}{|c|}{$\begin{array}{l}\text { 95\% Confidence } \\
\text { Interval }\end{array}$} \\
\hline & & & & & & $\begin{array}{l}\text { Lower } \\
\text { Bound }\end{array}$ & $\begin{array}{l}\text { Upper } \\
\text { Bound }\end{array}$ \\
\hline & & & $\begin{array}{l}\text { Elementary } \\
\text { school }\end{array}$ & -1.2353 & 0.079 & -2.5834 & 0.1128 \\
\hline & & \multirow{2}{*}{$\begin{array}{l}\text { Elementary } \\
\text { school }\end{array}$} & High school & 0.38462 & 0.75 & -0.9012 & 1.6704 \\
\hline & & & $\begin{array}{l}\text { Middle } \\
\text { School } \\
\end{array}$ & 1.23529 & 0.079 & -0.1128 & 2.5834 \\
\hline \multirow{6}{*}{7} & \multirow{6}{*}{$\begin{array}{l}\text { Nonparticipation in } \\
\text { classroom science } \\
\text { activities and labs }\end{array}$} & \multirow{2}{*}{ High school } & $\begin{array}{l}\text { Middle } \\
\text { School }\end{array}$ & $1.14027^{*}$ & 0.011 & 0.2236 & 2.057 \\
\hline & & & $\begin{array}{l}\text { Elementary } \\
\text { school }\end{array}$ & -0.3205 & 0.83 & -1.6517 & 1.0106 \\
\hline & & \multirow{2}{*}{ Middle School } & High school & $-1.14027^{*}$ & 0.011 & -2.057 & -0.2236 \\
\hline & & & $\begin{array}{l}\text { Elementary } \\
\text { school }\end{array}$ & $-1.46078^{*}$ & 0.038 & -2.8564 & -0.0651 \\
\hline & & \multirow{2}{*}{$\begin{array}{l}\text { Elementary } \\
\text { school }\end{array}$} & High school & 0.32051 & 0.83 & -1.0106 & 1.6517 \\
\hline & & & $\begin{array}{l}\text { Middle } \\
\text { School }\end{array}$ & $1.46078^{*}$ & 0.038 & 0.0651 & 2.8564 \\
\hline \multirow{6}{*}{8} & \multirow{6}{*}{$\begin{array}{l}\text { Attempts of cheating } \\
\text { during tests or } \\
\text { examinations }\end{array}$} & \multirow{2}{*}{ High school } & $\begin{array}{l}\text { Middle } \\
\text { School }\end{array}$ & $1.04751^{*}$ & 0.018 & 0.1525 & 1.9425 \\
\hline & & & $\begin{array}{l}\text { Elementary } \\
\text { school }\end{array}$ & $-1.42308^{*}$ & 0.029 & -2.7227 & -0.1234 \\
\hline & & \multirow{2}{*}{ Middle School } & High school & $-1.04751^{*}$ & 0.018 & -1.9425 & -0.1525 \\
\hline & & & $\begin{array}{l}\text { Elementary } \\
\text { school }\end{array}$ & $-2.47059^{*}$ & 0 & -3.8332 & -1.1079 \\
\hline & & \multirow{2}{*}{$\begin{array}{l}\text { Elementary } \\
\text { school }\end{array}$} & High school & $1.42308^{*}$ & 0.029 & 0.1234 & 2.7227 \\
\hline & & & $\begin{array}{l}\text { Middle } \\
\text { School }\end{array}$ & $2.47059^{*}$ & 0 & 1.1079 & 3.8332 \\
\hline \multirow[b]{2}{*}{9} & \multirow{2}{*}{$\begin{array}{l}\text { Students are chatting } \\
\text { among themselves } \\
\text { during science class }\end{array}$} & \multirow{2}{*}{ High school } & $\begin{array}{l}\text { Middle } \\
\text { School }\end{array}$ & 0.83032 & 0.106 & -0.1386 & 1.7993 \\
\hline & & & $\begin{array}{l}\text { Elementary } \\
\text { school }\end{array}$ & -1.0128 & 0.2 & -2.4198 & 0.3942 \\
\hline
\end{tabular}




\begin{tabular}{|c|c|c|c|c|c|c|c|}
\hline \multirow{6}{*}{$\mathbf{N}$} & \multirow{2}{*}{\multicolumn{3}{|c|}{ Dependent Variable }} & \multirow{2}{*}{$\begin{array}{l}\text { Mean } \\
\text { Differen } \\
\text { ce (I-J) }\end{array}$} & \multirow{2}{*}{$\begin{array}{l}\text { P- } \\
\text { value }\end{array}$} & \multicolumn{2}{|c|}{$\begin{array}{l}\text { 95\% Confidence } \\
\text { Interval }\end{array}$} \\
\hline & & & & & & $\begin{array}{l}\text { Lower } \\
\text { Bound }\end{array}$ & $\begin{array}{l}\text { Upper } \\
\text { Bound }\end{array}$ \\
\hline & & \multirow{2}{*}{ Middle School } & High school & -0.8303 & 0.106 & -1.7993 & 0.1386 \\
\hline & & & $\begin{array}{l}\text { Elementary } \\
\text { school }\end{array}$ & $-1.84314^{*}$ & 0.011 & -3.3183 & -0.368 \\
\hline & & \multirow{2}{*}{$\begin{array}{l}\text { Elementary } \\
\text { school }\end{array}$} & High school & 1.01282 & 0.2 & -0.3942 & 2.4198 \\
\hline & & & $\begin{array}{l}\text { Middle } \\
\text { School }\end{array}$ & $1.84314^{*}$ & 0.011 & 0.368 & 3.3183 \\
\hline \multirow{6}{*}{10} & \multirow{6}{*}{$\begin{array}{l}\text { Students interrupt } \\
\text { others }\end{array}$} & \multirow{2}{*}{ High school } & $\begin{array}{l}\text { Middle } \\
\text { School }\end{array}$ & 0.73077 & 0.16 & -0.2172 & 1.6788 \\
\hline & & & $\begin{array}{l}\text { Elementary } \\
\text { school }\end{array}$ & -0.9359 & 0.237 & -2.3124 & 0.4407 \\
\hline & & \multirow{2}{*}{ Middle School } & High school & -0.7308 & 0.16 & -1.6788 & 0.2172 \\
\hline & & & $\begin{array}{l}\text { Elementary } \\
\text { school }\end{array}$ & $-1.66667^{*}$ & 0.02 & -3.1099 & -0.2234 \\
\hline & & \multirow{2}{*}{$\begin{array}{l}\text { Elementary } \\
\text { school }\end{array}$} & High school & 0.9359 & 0.237 & -0.4407 & 2.3124 \\
\hline & & & $\begin{array}{l}\text { Middle } \\
\text { School }\end{array}$ & $1.66667^{*}$ & 0.02 & 0.2234 & 3.1099 \\
\hline \multirow{6}{*}{11} & \multirow{6}{*}{ Excessive absences } & \multirow{2}{*}{ High school } & $\begin{array}{l}\text { Middle } \\
\text { School }\end{array}$ & 0.02715 & 0.996 & -0.7533 & 0.8076 \\
\hline & & & $\begin{array}{l}\text { Elementary } \\
\text { school }\end{array}$ & $-1.21795^{*}$ & 0.033 & -2.3512 & -0.0847 \\
\hline & & \multirow{2}{*}{ Middle School } & High school & -0.0272 & 0.996 & -0.8076 & 0.7533 \\
\hline & & & $\begin{array}{l}\text { Elementary } \\
\text { school }\end{array}$ & $-1.24510^{*}$ & 0.038 & -2.4333 & -0.0569 \\
\hline & & \multirow{2}{*}{$\begin{array}{l}\text { Elementary } \\
\text { school }\end{array}$} & High school & $1.21795^{*}$ & 0.033 & 0.0847 & 2.3512 \\
\hline & & & $\begin{array}{l}\text { Middle } \\
\text { School }\end{array}$ & $1.24510^{*}$ & 0.038 & 0.0569 & 2.4333 \\
\hline & $\begin{array}{l}\text { Students come late } \\
\text { to science lessons }\end{array}$ & High school & $\begin{array}{l}\text { Middle } \\
\text { School }\end{array}$ & 0.55882 & 0.296 & -0.3376 & 1.4552 \\
\hline
\end{tabular}




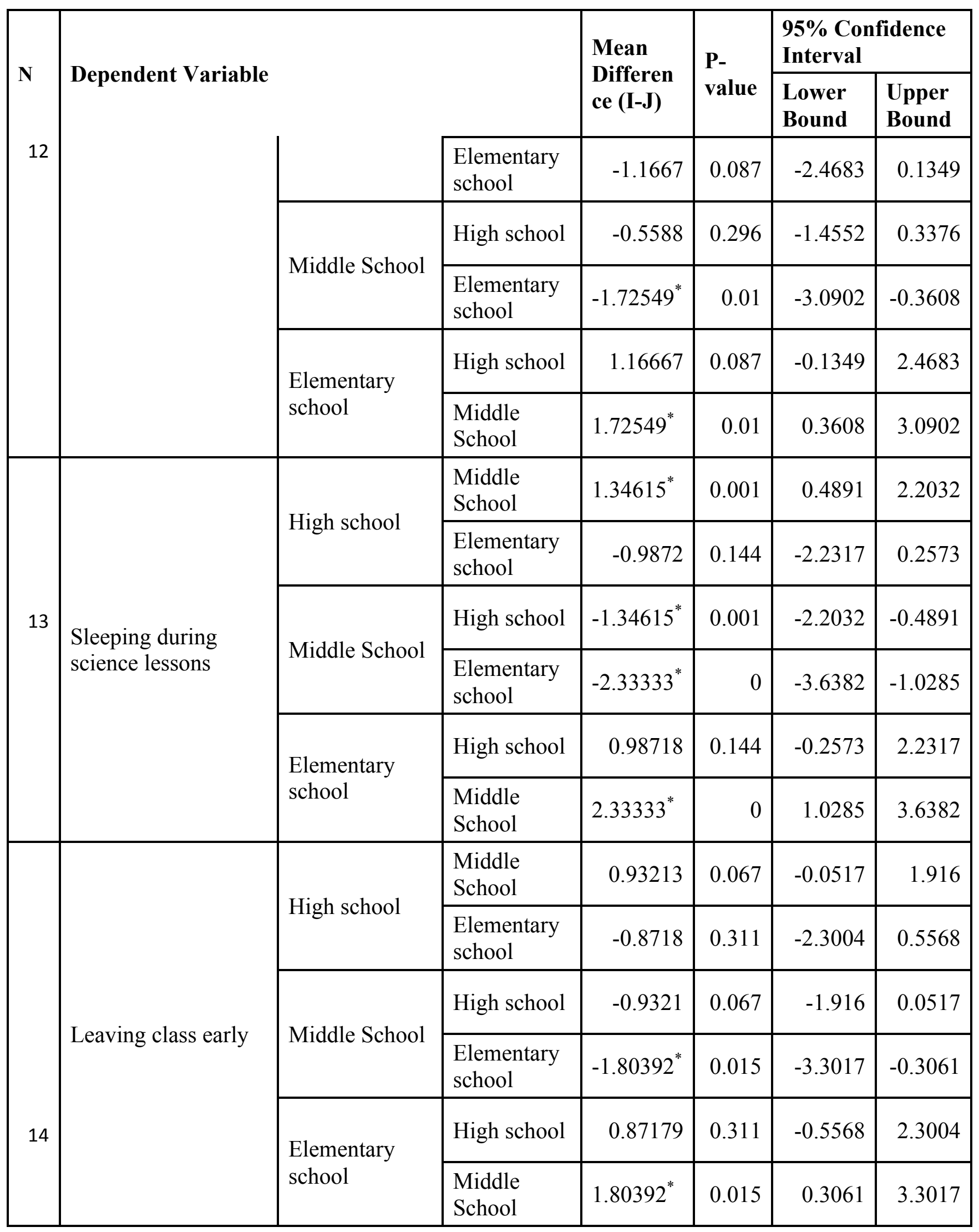




\begin{tabular}{|c|c|c|c|c|c|c|c|}
\hline \multirow{2}{*}{$\mathbf{N}$} & \multirow{2}{*}{\multicolumn{3}{|c|}{ Dependent Variable }} & \multirow{3}{*}{$\begin{array}{l}\begin{array}{l}\text { Mean } \\
\text { Differen } \\
\text { ce }(\mathbf{I}-J)\end{array} \\
1.25792^{*}\end{array}$} & \multirow{3}{*}{$\begin{array}{l}\begin{array}{l}\text { P- } \\
\text { value }\end{array} \\
0.013\end{array}$} & \multicolumn{2}{|c|}{$\begin{array}{l}\text { 95\% Confidence } \\
\text { Interval }\end{array}$} \\
\hline & & & & & & Lower & Upper \\
\hline \multirow{6}{*}{15} & \multirow{6}{*}{$\begin{array}{l}\text { Playing and using } \\
\text { mobile phones } \\
\text { during science class }\end{array}$} & \multirow{2}{*}{ High school } & $\begin{array}{l}\text { Middle } \\
\text { School }\end{array}$ & & & 0.2351 & 2.2807 \\
\hline & & & $\begin{array}{l}\text { Elementary } \\
\text { school }\end{array}$ & -0.9872 & 0.252 & -2.4724 & 0.498 \\
\hline & & \multirow{2}{*}{ Middle School } & High school & $-1.25792^{*}$ & 0.013 & -2.2807 & -0.2351 \\
\hline & & & $\begin{array}{l}\text { Elementary } \\
\text { school }\end{array}$ & $-2.24510^{*}$ & 0.003 & -3.8023 & -0.6879 \\
\hline & & \multirow{2}{*}{$\begin{array}{l}\text { Elementary } \\
\text { school }\end{array}$} & High school & 0.98718 & 0.252 & -0.498 & 2.4724 \\
\hline & & & $\begin{array}{l}\text { Middle } \\
\text { School }\end{array}$ & $2.24510^{*}$ & 0.003 & 0.6879 & 3.8023 \\
\hline \multirow{6}{*}{16} & \multirow{6}{*}{$\begin{array}{l}\text { Students reply to the } \\
\text { teacher in the } \\
\text { impolite manner }\end{array}$} & \multirow{2}{*}{ High school } & $\begin{array}{l}\text { Middle } \\
\text { School }\end{array}$ & 1.10633 & 0.06 & -0.0372 & 2.2498 \\
\hline & & & $\begin{array}{l}\text { Elementary } \\
\text { school }\end{array}$ & -0.5897 & 0.668 & -2.2502 & 1.0707 \\
\hline & & \multirow{2}{*}{ Middle School } & High school & -1.1063 & 0.06 & -2.2498 & 0.0372 \\
\hline & & & $\begin{array}{l}\text { Elementary } \\
\text { school }\end{array}$ & -1.6961 & 0.058 & -3.437 & 0.0448 \\
\hline & & \multirow{2}{*}{$\begin{array}{l}\text { Elementary } \\
\text { school }\end{array}$} & High school & 0.58974 & 0.668 & -1.0707 & 2.2502 \\
\hline & & & $\begin{array}{l}\text { Middle } \\
\text { School }\end{array}$ & 1.69608 & 0.058 & -0.0448 & 3.437 \\
\hline \multirow{5}{*}{17} & \multirow{5}{*}{$\begin{array}{l}\text { Harassment and } \\
\text { abuse of other } \\
\text { students }\end{array}$} & \multirow{2}{*}{ High school } & $\begin{array}{l}\text { Middle } \\
\text { School }\end{array}$ & $1.60633^{*}$ & 0.001 & 0.6264 & 2.5863 \\
\hline & & & $\begin{array}{l}\text { Elementary } \\
\text { school }\end{array}$ & -0.2564 & 0.901 & -1.6794 & 1.1665 \\
\hline & & \multirow{2}{*}{ Middle School } & High school & $-1.60633^{*}$ & 0.001 & -2.5863 & -0.6264 \\
\hline & & & $\begin{array}{l}\text { Elementary } \\
\text { school }\end{array}$ & $-1.86275^{*}$ & 0.011 & -3.3546 & -0.3708 \\
\hline & & $\begin{array}{l}\text { Elementary } \\
\text { school }\end{array}$ & High school & 0.25641 & 0.901 & -1.1665 & 1.6794 \\
\hline
\end{tabular}




\begin{tabular}{|c|c|c|c|c|c|c|c|}
\hline \multirow{3}{*}{$\mathbf{N}$} & \multirow{3}{*}{ Dependent Variable } & & & \multirow{2}{*}{$\begin{array}{l}\text { Mean } \\
\text { Differen } \\
\text { ce (I-J) }\end{array}$} & \multirow{2}{*}{$\begin{array}{l}P \text { - } \\
\text { value }\end{array}$} & \multicolumn{2}{|c|}{$\begin{array}{l}\text { 95\% Confidence } \\
\text { Interval }\end{array}$} \\
\hline & & & & & & $\begin{array}{l}\text { Lower } \\
\text { Bound }\end{array}$ & $\begin{array}{l}\text { Upper } \\
\text { Bound }\end{array}$ \\
\hline & & & $\begin{array}{l}\text { Middle } \\
\text { School }\end{array}$ & $1.86275^{*}$ & 0.011 & 0.3708 & 3.3546 \\
\hline \multirow{6}{*}{18} & \multirow{6}{*}{$\begin{array}{l}\text { Inappropriate out of } \\
\text { seat behavioral }\end{array}$} & \multirow{2}{*}{ High school } & $\begin{array}{l}\text { Middle } \\
\text { School }\end{array}$ & $1.13348^{*}$ & 0.02 & 0.1563 & 2.1107 \\
\hline & & & $\begin{array}{l}\text { Elementary } \\
\text { school }\end{array}$ & -0.8077 & 0.36 & -2.2266 & 0.6113 \\
\hline & & \multirow{2}{*}{ Middle School } & High school & $-1.13348^{*}$ & 0.02 & -2.1107 & -0.1563 \\
\hline & & & $\begin{array}{l}\text { Elementary } \\
\text { school }\end{array}$ & $-1.94118^{*}$ & 0.008 & -3.4289 & -0.4535 \\
\hline & & \multirow{2}{*}{$\begin{array}{l}\text { Elementary } \\
\text { school }\end{array}$} & High school & 0.80769 & 0.36 & -0.6113 & 2.2266 \\
\hline & & & $\begin{array}{l}\text { Middle } \\
\text { School }\end{array}$ & $1.94118^{*}$ & 0.008 & 0.4535 & 3.4289 \\
\hline \multirow{6}{*}{19} & \multirow{6}{*}{$\begin{array}{l}\text { Students do not } \\
\text { complete science } \\
\text { assignments on time }\end{array}$} & \multirow{2}{*}{ High school } & $\begin{array}{l}\text { Middle } \\
\text { School }\end{array}$ & 0.82579 & 0.129 & -0.1854 & 1.837 \\
\hline & & & $\begin{array}{l}\text { Elementary } \\
\text { school }\end{array}$ & -0.2821 & 0.888 & -1.7504 & 1.1863 \\
\hline & & \multirow{2}{*}{ Middle School } & High school & -0.8258 & 0.129 & -1.837 & 0.1854 \\
\hline & & & $\begin{array}{l}\text { Elementary } \\
\text { school }\end{array}$ & -1.1078 & 0.2 & -2.6473 & 0.4316 \\
\hline & & \multirow{2}{*}{$\begin{array}{l}\text { Elementary } \\
\text { school }\end{array}$} & High school & 0.28205 & 0.888 & -1.1863 & 1.7504 \\
\hline & & & $\begin{array}{l}\text { Middle } \\
\text { School }\end{array}$ & 1.10784 & 0.2 & -0.4316 & 2.6473 \\
\hline \multirow{4}{*}{20} & \multirow{4}{*}{$\begin{array}{l}\text { Lack of concern in } \\
\text { performance of } \\
\text { science activities and } \\
\text { homework }\end{array}$} & \multirow{2}{*}{ High school } & $\begin{array}{l}\text { Middle } \\
\text { School }\end{array}$ & 0.67195 & 0.223 & -0.2962 & 1.6401 \\
\hline & & & $\begin{array}{l}\text { Elementary } \\
\text { school }\end{array}$ & -0.7692 & 0.389 & -2.175 & 0.6365 \\
\hline & & \multirow{2}{*}{ Middle School } & High school & -0.672 & 0.223 & -1.6401 & 0.2962 \\
\hline & & & $\begin{array}{l}\text { Elementary } \\
\text { school }\end{array}$ & -1.4412 & 0.057 & -2.9151 & 0.0327 \\
\hline
\end{tabular}




\begin{tabular}{|c|c|c|c|c|c|c|c|}
\hline \multirow{4}{*}{$\mathbf{N}$} & \multirow{2}{*}{\multicolumn{3}{|c|}{ Dependent Variable }} & \multirow{2}{*}{$\begin{array}{l}\text { Mean } \\
\text { Differen } \\
\text { ce (I-J) }\end{array}$} & \multirow{2}{*}{$\begin{array}{l}\text { P- } \\
\text { value }\end{array}$} & \multicolumn{2}{|c|}{$\begin{array}{l}95 \% \text { Confidence } \\
\text { Interval }\end{array}$} \\
\hline & & & & & & $\begin{array}{l}\text { Lower } \\
\text { Bound }\end{array}$ & $\begin{array}{l}\text { Upper } \\
\text { Bound }\end{array}$ \\
\hline & & \multirow{2}{*}{$\begin{array}{l}\text { Elementary } \\
\text { school }\end{array}$} & High school & 0.76923 & 0.389 & -0.6365 & 2.175 \\
\hline & & & $\begin{array}{l}\text { Middle } \\
\text { School }\end{array}$ & 1.44118 & 0.057 & -0.0327 & 2.9151 \\
\hline
\end{tabular}

The disparity in perception of classroom behavioral challenges between elementary and middle school teachers was significant for most of the challenges except for four of them: lack of motivation to learn science, student reply to the teacher in the impolite manner, turning the assignments in after deadline, lack of concern in performance of science activities and homework.

There were also significant differences between elementary and high school science teachers in relation to four challenges: inappropriate school supplies $(p=0.001)$, cheating attempts during tests and examinations $(p=0.029)$, excessive absences $(p=0.033)$ and students negative perceptions about science lessons $(p=0.041)$.

Highly significant differences were found between middle school and high school science teachers in the following six behavioral challenges: sleeping during science lessons $(p=0.001)$, harassment and abuse of other students $(p=0.001)$, unwillingness to participate in classroom activities $(\mathrm{p}=0.011)$, playing and using mobile phones during science lessons $(\mathrm{p}=0.013)$, cheating attempts during tests and examinations $(\mathrm{p}=0.018)$, inappropriate out of seat behavioral $(p=0.02)$ and lack of readiness to learn science $(p=0.04)$.

\section{Interaction Effects for the Factors Gender and Years of Experience}

Next, the interaction effects of the independent variables, new science teacher gender, school level and years of experience on the dependent variable, level of behavioral classroom 
challenges were investigated. First, the interaction effects between new science teacher gender and years of experience on the level of behavioral classroom challenges were analyzed.

Table 21 shows the means and standard deviations for new science teacher gender and years of experience.

Table 21: Interactions between two factors: Gender and Experience

\begin{tabular}{|c|c|c|c|c|c|}
\hline $\mathbf{N}$ & Challenges & Gender & Experience & Mean & $\begin{array}{l}\text { Standard } \\
\text { Deviation } \\
\end{array}$ \\
\hline \multirow{6}{*}{1} & \multirow{6}{*}{$\begin{array}{l}\text { Students do not appear ready to } \\
\text { learn science }\end{array}$} & \multirow{3}{*}{ Male } & First-year & 2.43 & 1.4 \\
\hline & & & Second-year & 1.78 & 1.09 \\
\hline & & & Third-year & 2.42 & 1.24 \\
\hline & & \multirow{3}{*}{ Female } & First-year & 3 & \\
\hline & & & Second-year & & \\
\hline & & & Third-year & 2.05 & 1 \\
\hline \multirow{6}{*}{2} & \multirow{6}{*}{$\begin{array}{l}\text { Students have negative ideas } \\
\text { about science lessons }\end{array}$} & \multirow{3}{*}{ Male } & First-year & 2.57 & 1.62 \\
\hline & & & Second-year & 2.56 & 1.13 \\
\hline & & & Third-year & 2.5 & 1.37 \\
\hline & & \multirow{3}{*}{ Female } & First-year & 1 & \\
\hline & & & Second-year & & \\
\hline & & & Third-year & 2.1 & 0.97 \\
\hline \multirow{6}{*}{3} & \multirow{6}{*}{ Indifference to science lessons } & \multirow{3}{*}{ Male } & First-year & 2.43 & 1.13 \\
\hline & & & Second-year & 1.89 & 1.27 \\
\hline & & & Third-year & 2.33 & 1.5 \\
\hline & & \multirow{3}{*}{ Female } & First-year & 2 & \\
\hline & & & Second-year & & \\
\hline & & & Third-year & 2.1 & 0.97 \\
\hline \multirow{6}{*}{4} & \multirow{6}{*}{$\begin{array}{l}\text { Students do not have correct } \\
\text { supplies ready }\end{array}$} & \multirow{3}{*}{ Male } & First-year & 2.43 & 1.13 \\
\hline & & & Second-year & 2.22 & 1.2 \\
\hline & & & Third-year & 2.5 & 1.5 \\
\hline & & \multirow{3}{*}{ Female } & First-year & 2 & \\
\hline & & & Second-year & & \\
\hline & & & Third-year & 2.2 & 1 \\
\hline
\end{tabular}




\begin{tabular}{|c|c|c|c|c|c|}
\hline $\mathbf{N}$ & Challenges & Gender & Experience & Mean & $\begin{array}{l}\text { Standard } \\
\text { Deviation } \\
\end{array}$ \\
\hline \multirow{6}{*}{5} & \multirow{6}{*}{$\begin{array}{l}\text { Students ignore the teacher } \\
\text { instructions, orders and their } \\
\text { comments }\end{array}$} & \multirow{3}{*}{ Male } & First-year & 2.86 & 1.34 \\
\hline & & & Second-year & 2.67 & 1.32 \\
\hline & & & Third-year & 3.25 & 1.36 \\
\hline & & \multirow{3}{*}{ Female } & First-year & 4 & \\
\hline & & & Second-year & & \\
\hline & & & Third-year & 1.8 & 0.95 \\
\hline \multirow{6}{*}{6} & \multirow{6}{*}{$\begin{array}{l}\text { Lack of motivation to learn } \\
\text { science }\end{array}$} & \multirow{3}{*}{ Male } & First-year & 2.71 & 1.38 \\
\hline & & & Second-year & 3 & 1.11 \\
\hline & & & Third-year & 2.17 & 1.47 \\
\hline & & \multirow{3}{*}{ Female } & First-year & 4 & \\
\hline & & & Second-year & & \\
\hline & & & Third-year & 2 & 0.97 \\
\hline \multirow{6}{*}{7} & \multirow{6}{*}{$\begin{array}{l}\text { Nonparticipation in classroom } \\
\text { science activities and labs }\end{array}$} & \multirow{3}{*}{ Male } & First-year & 2.71 & 1.5 \\
\hline & & & Second-year & 2.78 & 1.39 \\
\hline & & & Third-year & 2.67 & 1.44 \\
\hline & & \multirow{3}{*}{ Female } & First-year & 2 & \\
\hline & & & Second-year & & \\
\hline & & & Third-year & 2.2 & 1.24 \\
\hline \multirow{6}{*}{8} & \multirow{6}{*}{$\begin{array}{l}\text { Attempts of cheating during } \\
\text { tests or examinations }\end{array}$} & \multirow{3}{*}{ Male } & First-year & 2.43 & 1.51 \\
\hline & & & Second-year & 2.22 & 1.48 \\
\hline & & & Third-year & 2.17 & 1.19 \\
\hline & & \multirow{3}{*}{ Female } & First-year & 4 & \\
\hline & & & Second-year & & \\
\hline & & & Third-year & 2.5 & 1.5 \\
\hline \multirow{6}{*}{9} & \multirow{6}{*}{$\begin{array}{l}\text { Students are chatting among } \\
\text { themselves during science class }\end{array}$} & \multirow{3}{*}{ Male } & First-year & 2.57 & 1.13 \\
\hline & & & Second-year & 2.44 & 1.42 \\
\hline & & & Third-year & 2.58 & 1.44 \\
\hline & & \multirow{3}{*}{ Female } & First-year & 4 & \\
\hline & & & Second-year & & \\
\hline & & & Third-year & 2.35 & 1.5 \\
\hline \multirow{5}{*}{10} & \multirow{5}{*}{ Students interrupt others } & \multirow{3}{*}{ Male } & First-year & 3 & 1.15 \\
\hline & & & Second-year & 2.78 & 1.39 \\
\hline & & & Third-year & 2.58 & 1.16 \\
\hline & & \multirow{2}{*}{ Female } & First-year & 5 & \\
\hline & & & Second-year & & \\
\hline
\end{tabular}




\begin{tabular}{|c|c|c|c|c|c|}
\hline $\mathbf{N}$ & Challenges & Gender & Experience & Mean & $\begin{array}{l}\text { Standard } \\
\text { Deviation } \\
\end{array}$ \\
\hline & & & Third-year & 2.25 & 1.41 \\
\hline \multirow{6}{*}{11} & \multirow{6}{*}{ Excessive absences } & \multirow{3}{*}{ Male } & First-year & 1.57 & 0.79 \\
\hline & & & Second-year & 2.33 & 1.22 \\
\hline & & & Third-year & 2 & 1.35 \\
\hline & & \multirow{3}{*}{ Female } & First-year & 1 & \\
\hline & & & Second-year & & \\
\hline & & & Third-year & 1.45 & 0.89 \\
\hline \multirow{6}{*}{12} & \multirow{6}{*}{$\begin{array}{l}\text { Students come late to science } \\
\text { lessons }\end{array}$} & \multirow{3}{*}{ Male } & First-year & 2.57 & 1.27 \\
\hline & & & Second-year & 3 & 1.12 \\
\hline & & & Third-year & 2.75 & 1.42 \\
\hline & & \multirow{3}{*}{ Female } & First-year & 2 & \\
\hline & & & Second-year & & \\
\hline & & & Third-year & 2 & 1.21 \\
\hline \multirow{6}{*}{13} & \multirow{6}{*}{ Sleeping during science lessons } & \multirow{3}{*}{ Male } & First-year & 2.57 & 0.98 \\
\hline & & & Second-year & 3.33 & 1 \\
\hline & & & Third-year & 3.08 & 1.44 \\
\hline & & \multirow{3}{*}{ Female } & First-year & 5 & \\
\hline & & & Second-year & & \\
\hline & & & Third-year & 2.85 & 1.57 \\
\hline \multirow{6}{*}{14} & \multirow{6}{*}{ Leaving class early } & \multirow{3}{*}{ Male } & First-year & 3 & 1.53 \\
\hline & & & Second-year & 3.22 & 1.39 \\
\hline & & & Third-year & 3.67 & 1.23 \\
\hline & & \multirow{3}{*}{ Female } & First-year & 5 & \\
\hline & & & Second-year & & \\
\hline & & & Third-year & 3 & 1.49 \\
\hline \multirow{6}{*}{15} & \multirow{6}{*}{$\begin{array}{l}\text { Playing and using mobile } \\
\text { phones during science class }\end{array}$} & \multirow{3}{*}{ Male } & First-year & 3.14 & 1.21 \\
\hline & & & Second-year & 3.78 & 1.39 \\
\hline & & & Third-year & 3.92 & 1.38 \\
\hline & & \multirow{3}{*}{ Female } & First-year & 5 & \\
\hline & & & Second-year & & \\
\hline & & & Third-year & 3.25 & 1.77 \\
\hline \multirow{4}{*}{16} & \multirow{4}{*}{$\begin{array}{l}\text { Students reply to the teacher in } \\
\text { the impolite manner }\end{array}$} & \multirow{3}{*}{ Male } & First-year & 3.43 & 1.27 \\
\hline & & & Second-year & 3.44 & 1.74 \\
\hline & & & Third-year & 3.67 & 1.44 \\
\hline & & Female & First-year & 5 & \\
\hline
\end{tabular}




\begin{tabular}{|c|c|c|c|c|c|}
\hline $\mathbf{N}$ & Challenges & Gender & Experience & Mean & $\begin{array}{l}\text { Standard } \\
\text { Deviation }\end{array}$ \\
\hline & & & Second-year & & \\
\hline & & & Third-year & 2.8 & 1.74 \\
\hline \multirow{6}{*}{17} & \multirow{6}{*}{$\begin{array}{l}\text { Harassment and abuse of other } \\
\text { students }\end{array}$} & \multirow{3}{*}{ Male } & First-year & 3.29 & 1.5 \\
\hline & & & Second-year & 3.89 & 1.17 \\
\hline & & & Third-year & 3.92 & 1.08 \\
\hline & & \multirow{3}{*}{ Female } & First-year & 5 & \\
\hline & & & Second-year & & \\
\hline & & & Third-year & 3.2 & 1.82 \\
\hline \multirow{6}{*}{18} & \multirow{6}{*}{$\begin{array}{l}\text { Inappropriate out of seat } \\
\text { behavioral }\end{array}$} & \multirow{3}{*}{ Male } & First-year & 2.71 & 1.38 \\
\hline & & & Second-year & 3 & 1.32 \\
\hline & & & Third-year & 2.92 & 1.44 \\
\hline & & \multirow{3}{*}{ Female } & First-year & 5 & \\
\hline & & & Second-year & & \\
\hline & & & Third-year & 2.8 & 1.54 \\
\hline \multirow{6}{*}{19} & \multirow{6}{*}{$\begin{array}{l}\text { Students do not complete } \\
\text { science assignments on time }\end{array}$} & \multirow{3}{*}{ Male } & First-year & 2.57 & 1.51 \\
\hline & & & Second-year & 3.22 & 1.42 \\
\hline & & & Third-year & 2.67 & 1.44 \\
\hline & & \multirow{3}{*}{ Female } & First-year & 4 & \\
\hline & & & Second-year & & \\
\hline & & & Third-year & 2.3 & 1.26 \\
\hline \multirow{6}{*}{20} & \multirow{6}{*}{$\begin{array}{l}\text { Lack of concern in performance } \\
\text { of science activities and } \\
\text { homework }\end{array}$} & \multirow{3}{*}{ Male } & First-year & 2.29 & 1.11 \\
\hline & & & Second-year & 3.44 & 1.59 \\
\hline & & & Third-year & 2.58 & 1.44 \\
\hline & & \multirow{3}{*}{ Female } & First-year & 4 & \\
\hline & & & Second-year & & \\
\hline & & & Third-year & 2.25 & 1.12 \\
\hline
\end{tabular}

Overall, the highest level of behavioral challenges were observed in first year and third year female science teachers $($ mean $=1)$. First year female science teachers perceived student absenteeism $($ mean $=1)$ and negative conceptions about science $($ mean $=1)$ as the top two major challenges that they have encountered in their professions. Third-year female science 
teachers agreed with first year female science teachers on student absenteeism $($ mean $=1.45)$ but gave higher rankings to the challenges related to the lowest rate at which student follow teacher's instructions $($ mean $=1.8)$. Student absenteeism $($ mean $=1.57)$ and indifference about science activities and homework performances $($ mean $=2.29)$ were the top two behavioral challenges for first year male science teachers. Second year male science teachers perceived student lack of readiness to learn science $($ mean $=2.29)$, indifference to science lessons $($ mean $=2.29)$ and inappropriate school supplies $($ mean $=2.29)$ as their most important challenges. For third year men science teachers, the top three challenges were student absenteeism $($ mean $=2)$, lack of motivation to learn science $($ mean $=2.17)$ and attempts of cheating during tests or examinations $($ mean $=2.17)$.

A two-way ANOVA test with a level of significance of 0.05 was performed to determine if there was a significant interaction effect between new science teacher gender and their years of experience on the level of behavioral classroom challenges that they faced. The results of this two-way ANOVA are reported in Table 22. For all the challenges, the ANOVA proved a nonsignificant main effect for new science teacher gender, a nonsignificant main effect of new science teacher experience and a nonsignificant interaction effect between new science teacher gender and teaching experience. 
Table 22: Significance of Interactions between two factors: Gender and Experience

\begin{tabular}{|c|c|c|c|c|}
\hline $\mathbf{N}$ & Challenges & Factors & $\mathbf{F}$ & P-value \\
\hline \multirow{3}{*}{1} & \multirow{3}{*}{$\begin{array}{l}\text { Students do not appear ready to learn } \\
\text { science }\end{array}$} & Gender & 0.025 & 0.874 \\
\hline & & experience & 1.173 & 0.319 \\
\hline & & Gender*Experience & 0.531 & 0.47 \\
\hline \multirow{3}{*}{2} & \multirow{3}{*}{$\begin{array}{l}\text { Students have negative ideas about science } \\
\text { lessons }\end{array}$} & Gender & 1.949 & 0.17 \\
\hline & & experience & 0.265 & 0.768 \\
\hline & & Gender*Experience & 0.688 & 0.411 \\
\hline \multirow{3}{*}{3} & \multirow{3}{*}{ Indifference to science lessons } & Gender & 0.24 & 0.627 \\
\hline & & experience & 0.506 & 0.606 \\
\hline & & Gender*Experience & 0.02 & 0.886 \\
\hline \multirow{3}{*}{4} & \multirow{3}{*}{ Students do not have correct supplies ready } & Gender & 0.288 & 0.594 \\
\hline & & experience & 0.148 & 0.863 \\
\hline & & Gender*Experience & 0.009 & 0.925 \\
\hline \multirow{3}{*}{5} & \multirow{3}{*}{$\begin{array}{l}\text { Students ignore the teacher instructions, } \\
\text { orders and their comments }\end{array}$} & Gender & 0.052 & 0.82 \\
\hline & & experience & 1.155 & 0.324 \\
\hline & & Gender*Experience & 3.72 & 0.06 \\
\hline \multirow{3}{*}{6} & \multirow{3}{*}{ Lack of motivation to learn science } & Gender & 0.684 & 0.413 \\
\hline & & experience & 2.573 & 0.088 \\
\hline & & Gender*Experience & 1.153 & 0.289 \\
\hline \multirow{3}{*}{7} & \multirow{3}{*}{$\begin{array}{l}\text { Nonparticipation in classroom science } \\
\text { activities and labs }\end{array}$} & Gender & 0.595 & 0.445 \\
\hline & & experience & 0.016 & 0.984 \\
\hline & & Gender*Experience & 0.026 & 0.872 \\
\hline \multirow{3}{*}{8} & \multirow{3}{*}{$\begin{array}{l}\text { Attempts of cheating during tests or } \\
\text { examinations }\end{array}$} & Gender & 1.391 & 0.245 \\
\hline & & experience & 0.597 & 0.555 \\
\hline & & Gender*Experience & 0.588 & 0.447 \\
\hline \multirow{3}{*}{9} & \multirow{3}{*}{$\begin{array}{l}\text { Students are chatting among themselves } \\
\text { during science class }\end{array}$} & Gender & 0.551 & 0.462 \\
\hline & & experience & 0.531 & 0.592 \\
\hline & & Gender*Experience & 1.065 & 0.308 \\
\hline \multirow{3}{*}{10} & \multirow{3}{*}{ Students interrupt others } & Gender & 1.256 & 0.268 \\
\hline & & experience & 2.274 & 0.115 \\
\hline & & Gender*Experience & 2.463 & 0.124 \\
\hline \multirow{3}{*}{11} & \multirow{3}{*}{ Excessive absences } & Gender & 0.856 & 0.36 \\
\hline & & experience & 0.985 & 0.381 \\
\hline & & Gender*Experience & 0 & 0.986 \\
\hline & Students come late to science lessons & Gender & 0.86 & 0.359 \\
\hline
\end{tabular}




\begin{tabular}{|c|c|c|c|c|}
\hline $\mathbf{N}$ & Challenges & Factors & $\mathbf{F}$ & P-value \\
\hline \multirow[t]{2}{*}{12} & & experience & 0.219 & 0.804 \\
\hline & & Gender*Experience & 0.016 & 0.901 \\
\hline \multirow{3}{*}{13} & \multirow{3}{*}{ Sleeping during science lessons } & Gender & 1.997 & 0.165 \\
\hline & & experience & 1.025 & 0.367 \\
\hline & & Gender*Experience & 2.937 & 0.094 \\
\hline \multirow{3}{*}{14} & \multirow{3}{*}{ Leaving class early } & Gender & 0.695 & 0.409 \\
\hline & & experience & 0.357 & 0.702 \\
\hline & & Gender*Experience & 2.779 & 0.103 \\
\hline \multirow{3}{*}{15} & \multirow{3}{*}{$\begin{array}{l}\text { Playing and using mobile phones during } \\
\text { science class }\end{array}$} & Gender & 0.465 & 0.499 \\
\hline & & experience & 0.248 & 0.781 \\
\hline & & Gender*Experience & 2.09 & 0.155 \\
\hline \multirow{3}{*}{16} & \multirow{3}{*}{$\begin{array}{l}\text { Students reply to the teacher in the } \\
\text { impolite manner }\end{array}$} & Gender & 0.15 & 0.7 \\
\hline & & experience & 0.587 & 0.56 \\
\hline & & Gender*Experience & 1.801 & 0.186 \\
\hline \multirow{3}{*}{17} & \multirow{3}{*}{ Harassment and abuse of other students } & Gender & 0.342 & 0.562 \\
\hline & & experience & 0.365 & 0.696 \\
\hline & & Gender*Experience & 2.029 & 0.161 \\
\hline \multirow{3}{*}{18} & \multirow{3}{*}{ Inappropriate out of seat behavioral } & Gender & 1.734 & 0.195 \\
\hline & & experience & 0.811 & 0.451 \\
\hline & & Gender*Experience & 2.127 & 0.152 \\
\hline \multirow{3}{*}{19} & \multirow{3}{*}{$\begin{array}{l}\text { Students do not complete science } \\
\text { assignments on time }\end{array}$} & Gender & 0.462 & 0.5 \\
\hline & & experience & 1.17 & 0.32 \\
\hline & & Gender*Experience & 1.321 & 0.257 \\
\hline \multirow{3}{*}{20} & \multirow{3}{*}{$\begin{array}{l}\text { Lack of concern in performance of science } \\
\text { activities and homework }\end{array}$} & Gender & 0.885 & 0.352 \\
\hline & & experience & 2.421 & 0.101 \\
\hline & & Gender*Experience & 1.945 & 0.17 \\
\hline
\end{tabular}

\section{Interaction Effects for the Factors Gender and School Level}

Second, the interaction effects between new science teacher gender and new science teacher school levels on the level of behavioral classroom challenges were examined. The means and standard deviations for new science teacher gender and new science teacher school level were calculated and shown in Table 23. 
Table 23: Interactions between two factors: Gender and School Level

\begin{tabular}{|c|c|c|c|c|c|}
\hline $\mathbf{N}$ & Challenges & Gender & Level & Mean & $\begin{array}{l}\text { Standard } \\
\text { Deviation }\end{array}$ \\
\hline \multirow{6}{*}{1} & \multirow{6}{*}{$\begin{array}{l}\text { Students do not appear ready to } \\
\text { learn science }\end{array}$} & \multirow{3}{*}{ Male } & High School & 2.18 & 1.19 \\
\hline & & & Middle School & 1.75 & 1.04 \\
\hline & & & Elementary School & 3.67 & 1.16 \\
\hline & & \multirow{3}{*}{ Female } & High School & 2.56 & 0.88 \\
\hline & & & Middle School & 1.33 & 0.5 \\
\hline & & & Elementary School & 3 & 1 \\
\hline \multirow{6}{*}{2} & \multirow{6}{*}{$\begin{array}{l}\text { Students have negative ideas about } \\
\text { science lessons }\end{array}$} & \multirow{3}{*}{ Male } & High School & 2.47 & 1.42 \\
\hline & & & Middle School & 2 & 0.93 \\
\hline & & & Elementary School & 4.33 & 0.58 \\
\hline & & \multirow{3}{*}{ Female } & High School & 2.33 & 1 \\
\hline & & & Middle School & 1.44 & 0.53 \\
\hline & & & Elementary School & 3 & 1 \\
\hline \multirow{6}{*}{3} & \multirow{6}{*}{ Indifference to science lessons } & \multirow{3}{*}{ Male } & High School & 2.12 & 1.27 \\
\hline & & & Middle School & 1.88 & 1.13 \\
\hline & & & Elementary School & 3.67 & 1.53 \\
\hline & & \multirow{3}{*}{ Female } & High School & 2.44 & 0.88 \\
\hline & & & Middle School & 1.44 & 0.53 \\
\hline & & & Elementary School & 3 & 1 \\
\hline \multirow{6}{*}{4} & \multirow{6}{*}{$\begin{array}{l}\text { Students do not have correct } \\
\text { supplies ready }\end{array}$} & \multirow{3}{*}{ Male } & High School & 2.18 & 1.31 \\
\hline & & & Middle School & 2 & 0.93 \\
\hline & & & Elementary School & 4.67 & 0.58 \\
\hline & & \multirow{3}{*}{ Female } & High School & 2.56 & 0.73 \\
\hline & & & Middle School & 1.44 & 0.53 \\
\hline & & & Elementary School & 3.33 & 1.15 \\
\hline \multirow{6}{*}{5} & \multirow{6}{*}{$\begin{array}{l}\text { Students ignore the teacher } \\
\text { instructions, orders and their } \\
\text { comments }\end{array}$} & \multirow{3}{*}{ Male } & High School & 2.88 & 1.27 \\
\hline & & & Middle School & 2.63 & 1.41 \\
\hline & & & Elementary School & 4.33 & 0.58 \\
\hline & & \multirow{3}{*}{ Female } & High School & 2.11 & 1.05 \\
\hline & & & Middle School & 1.22 & 0.44 \\
\hline & & & Elementary School & 3.33 & 0.58 \\
\hline \multirow[b]{3}{*}{6} & \multirow{3}{*}{ Lack of motivation to learn science } & \multirow{3}{*}{ Male } & High School & 2.65 & 1.32 \\
\hline & & & Middle School & 2.25 & 1.28 \\
\hline & & & Elementary School & 3 & 2 \\
\hline
\end{tabular}




\begin{tabular}{|c|c|c|c|c|c|}
\hline $\mathbf{N}$ & Challenges & Gender & Level & Mean & $\begin{array}{l}\text { Standard } \\
\text { Deviation }\end{array}$ \\
\hline & & & High School & 2.56 & 0.88 \\
\hline & & Female & Middle School & 1.33 & 0.71 \\
\hline & & & Elementary School & 3 & 1 \\
\hline \multirow{6}{*}{7} & \multirow{6}{*}{$\begin{array}{l}\text { Nonparticipation in classroom } \\
\text { science activities and labs }\end{array}$} & \multirow{3}{*}{ Male } & High School & 2.94 & 1.25 \\
\hline & & & Middle School & 2.13 & 1.46 \\
\hline & & & Elementary School & 3 & 2 \\
\hline & & \multirow{3}{*}{ Female } & High School & 2.67 & 1.22 \\
\hline & & & Middle School & 1.33 & 0.71 \\
\hline & & & Elementary School & 3.17 & 0.58 \\
\hline \multirow{6}{*}{8} & \multirow{6}{*}{$\begin{array}{l}\text { Attempts of cheating during tests } \\
\text { or examinations }\end{array}$} & \multirow{3}{*}{ Male } & High School & 2.3 & 1.4 \\
\hline & & & Middle School & 1.63 & 0.92 \\
\hline & & & Elementary School & 3.67 & 0.58 \\
\hline & & \multirow{3}{*}{ Female } & High School & 3.11 & 1.27 \\
\hline & & & Middle School & 1.44 & 1 \\
\hline & & & Elementary School & 4.33 & 0.58 \\
\hline \multirow{6}{*}{9} & \multirow{6}{*}{$\begin{array}{l}\text { Students are chatting among } \\
\text { themselves during science class }\end{array}$} & \multirow{3}{*}{ Male } & High School & 2.53 & 1.33 \\
\hline & & & Middle School & 2.38 & 1.51 \\
\hline & & & Elementary School & 3 & 1 \\
\hline & & \multirow{3}{*}{ Female } & High School & 2.89 & 1.54 \\
\hline & & & Middle School & 1.33 & 0.5 \\
\hline & & & Elementary School & 4.33 & 0.58 \\
\hline \multirow{6}{*}{10} & \multirow{6}{*}{ Students interrupt others } & \multirow{3}{*}{ Male } & High School & 2.65 & 1.27 \\
\hline & & & Middle School & 2.88 & 1.25 \\
\hline & & & Elementary School & 3 & 1 \\
\hline & & \multirow{3}{*}{ Female } & High School & 2.89 & 1.45 \\
\hline & & & Middle School & 1.22 & 0.44 \\
\hline & & & Elementary School & 4.33 & 0.58 \\
\hline \multirow{6}{*}{11} & \multirow{6}{*}{ Excessive absences } & \multirow{3}{*}{ Male } & High School & 1.82 & 1.13 \\
\hline & & & Middle School & 2.12 & 1.24 \\
\hline & & & Elementary School & 2.67 & 1.53 \\
\hline & & \multirow{3}{*}{ Female } & High School & 1.22 & 0.67 \\
\hline & & & Middle School & 1.11 & 0.33 \\
\hline & & & Elementary School & 3 & 1 \\
\hline & \multirow{2}{*}{$\begin{array}{l}\text { Students come late to science } \\
\text { lessons }\end{array}$} & \multirow{2}{*}{ Male } & High School & 2.71 & 1.21 \\
\hline & & & Middle School & 2.75 & 1.58 \\
\hline
\end{tabular}




\begin{tabular}{|c|c|c|c|c|c|}
\hline $\mathbf{N}$ & Challenges & Gender & Level & Mean & $\begin{array}{l}\text { Standard } \\
\text { Deviation }\end{array}$ \\
\hline \multirow[t]{4}{*}{12} & & & Elementary School & 3.33 & 0.58 \\
\hline & & \multirow{3}{*}{ Female } & High School & 2.11 & 1.05 \\
\hline & & & Middle School & 1.22 & 0.44 \\
\hline & & & Elementary School & 4 & 0 \\
\hline \multirow{6}{*}{13} & \multirow{6}{*}{ Sleeping during science lessons } & \multirow{3}{*}{ Male } & High School & 3.12 & 1.11 \\
\hline & & & Middle School & 2.38 & 1.19 \\
\hline & & & Elementary School & 4.33 & 0.58 \\
\hline & & \multirow{3}{*}{ Female } & High School & 3.78 & 1.3 \\
\hline & & & Middle School & 1.67 & 1.12 \\
\hline & & & Elementary School & 4.33 & 0.58 \\
\hline \multirow{6}{*}{14} & \multirow{6}{*}{ Leaving class early } & \multirow{3}{*}{ Male } & High School & 3.35 & 1.32 \\
\hline & & & Middle School & 3 & 1.51 \\
\hline & & & Elementary School & 4.33 & 0.58 \\
\hline & & \multirow{3}{*}{ Female } & High School & 3.67 & 1.41 \\
\hline & & & Middle School & 2.11 & 1.27 \\
\hline & & & Elementary School & 4.33 & 0.58 \\
\hline \multirow{6}{*}{15} & \multirow{6}{*}{$\begin{array}{l}\text { Playing and using mobile phones } \\
\text { during science class }\end{array}$} & \multirow{3}{*}{ Male } & High School & 3.71 & 1.26 \\
\hline & & & Middle School & 3.25 & 1.58 \\
\hline & & & Elementary School & 4.67 & 0.58 \\
\hline & & \multirow{3}{*}{ Female } & High School & 4.11 & 1.54 \\
\hline & & & Middle School & 2 & 1.32 \\
\hline & & & Elementary School & 5 & 0 \\
\hline \multirow{6}{*}{16} & \multirow{6}{*}{$\begin{array}{l}\text { Students reply to the teacher in the } \\
\text { impolite manner }\end{array}$} & \multirow{3}{*}{ Male } & High School & 3.82 & 1.33 \\
\hline & & & Middle School & 3 & 1.69 \\
\hline & & & Elementary School & 3.33 & 1.53 \\
\hline & & \multirow{3}{*}{ Female } & High School & 3.11 & 1.83 \\
\hline & & & Middle School & 2 & 1.32 \\
\hline & & & Elementary School & 5 & 0 \\
\hline \multirow{6}{*}{17} & \multirow{6}{*}{$\begin{array}{l}\text { Harassment and abuse of other } \\
\text { students }\end{array}$} & \multirow{3}{*}{ Male } & High School & 4.12 & 0.93 \\
\hline & & & Middle School & 3 & 1.51 \\
\hline & & & Elementary School & 3.67 & 1.15 \\
\hline & & \multirow{3}{*}{ Female } & High School & 4 & 1.73 \\
\hline & & & Middle School & 2 & 1.32 \\
\hline & & & Elementary School & 5 & 0 \\
\hline & Inappropriate out of seat & Male & High School & 3.12 & 1.32 \\
\hline
\end{tabular}




\begin{tabular}{|c|c|c|c|c|c|}
\hline $\mathbf{N}$ & Challenges & Gender & Level & Mean & $\begin{array}{l}\text { Standard } \\
\text { Deviation }\end{array}$ \\
\hline \multirow{5}{*}{18} & \multirow[t]{5}{*}{ behavioral } & & Middle School & 2.13 & 1.36 \\
\hline & & & Elementary School & 3.67 & 0.58 \\
\hline & & \multirow{3}{*}{ Female } & High School & 3.33 & 1.73 \\
\hline & & & Middle School & 2 & 1 \\
\hline & & & Elementary School & 4.33 & 1.15 \\
\hline \multirow{6}{*}{19} & \multirow{6}{*}{$\begin{array}{l}\text { Students do not complete science } \\
\text { assignments on time }\end{array}$} & \multirow{3}{*}{ Male } & High School & 3.06 & 1.52 \\
\hline & & & Middle School & 2.25 & 1.39 \\
\hline & & & Elementary School & 3 & 1 \\
\hline & & \multirow{3}{*}{ Female } & High School & 2.56 & 1.67 \\
\hline & & & Middle School & 1.89 & 0.78 \\
\hline & & & Elementary School & 3.33 & 0.58 \\
\hline \multirow{6}{*}{20} & \multirow{6}{*}{$\begin{array}{l}\text { Lack of concern in performance of } \\
\text { science activities and homework }\end{array}$} & \multirow{3}{*}{ Male } & High School & 2.88 & 1.54 \\
\hline & & & Middle School & 2.25 & 1.39 \\
\hline & & & Elementary School & 3.67 & 0.58 \\
\hline & & \multirow{3}{*}{ Female } & High School & 2.44 & 1.42 \\
\hline & & & Middle School & 1.89 & 0.78 \\
\hline & & & Elementary School & 3.33 & $\overline{0.58}$ \\
\hline
\end{tabular}

Table 23 results suggest that female science teachers in middle schools faced the most important behavioral challenges in their classrooms. They felt that most of their students were not only missing too many science classes (mean $=1.11$ ) but also were ignoring their instructions, orders and comments (mean $=1.22)$ and interrupt one another in the classroom $($ mean $=1.22)$. As compared to female middle school science teachers, female high school science teachers gave significantly higher challenge seriousness ratings for student absenteeism, $($ mean $=1.22)$, student ignoring their instructions, orders and comments $($ mean $=2.11)$ and student coming late to science lessons $($ mean $=2.11)$. Female science teachers working in elementary schools said that their top challenges are student lack of readiness to learn science 
$($ mean $=3)$, negative conceptions about science $($ mean $=3)$ and indifference to science lessons $($ mean $=3)$.

According to the results of Table 23, male science teachers in middle schools felt the most challenged by behavioral aspects of teaching. Their biggest challenges were the majority of their students are trying to cheat during examinations and tests (mean $=1.63)$, appear not prepare to learn science $($ mean $=1.75)$ and are indifferent to science lessons $($ mean $=1.88)$. In addition to student absenteeism $($ mean $=1.82)$, indifference to science lessons $($ mean $=2.12)$ and lack of readiness to learn science $($ mean $=2.18)$ were the top three challenges faced by male new science teachers in high schools. Male science teachers in elementary schools faced their biggest challenges dealing with student attendance to science lessons (mean $=2.67$ ).

A $2 \times 3$ ANOVA was conducted with new science teacher gender having two categories: male and female, and new science teacher school level having three categories: elementary school, middle school and high school. The results of the ANOVA are presented in table 24.

Table 24: Significance of Interactions between two factors: Gender and School Level

\begin{tabular}{|c|c|c|c|c|}
\hline $\mathbf{N}$ & Challenges & Factors & $\mathbf{F}$ & P-value \\
\hline \multirow{3}{*}{1} & \multirow{3}{*}{ Students do not appear ready to learn science } & Gender & 0.464 & 0.499 \\
\hline & & Level & 7.872 & 0.001 \\
\hline & & Gender*Level & 1.115 & 0.337 \\
\hline \multirow{3}{*}{2} & \multirow{3}{*}{$\begin{array}{l}\text { Students have negative ideas about science } \\
\text { lessons }\end{array}$} & Gender & 3.219 & 0.08 \\
\hline & & Level & 7.188 & 0.002 \\
\hline & & Gender*Level & 0.754 & 0.477 \\
\hline \multirow{3}{*}{3} & \multirow{3}{*}{ Indifference to science lessons } & Gender & 0.478 & 0.493 \\
\hline & & Level & 5.532 & 0.007 \\
\hline & & Gender*Level & 0.869 & 0.427 \\
\hline
\end{tabular}




\begin{tabular}{|c|c|c|c|c|}
\hline $\mathbf{N}$ & Challenges & Factors & $\mathbf{F}$ & P-value \\
\hline \multirow{3}{*}{4} & \multirow{3}{*}{ Students do not have correct supplies ready } & Gender & 2.521 & 0.12 \\
\hline & & Level & 13.651 & 0 \\
\hline & & Gender*Level & 2.629 & 0.084 \\
\hline \multirow{3}{*}{5} & \multirow{3}{*}{$\begin{array}{l}\text { Students ignore the teacher instructions, orders } \\
\text { and their comments }\end{array}$} & Gender & 7.854 & 0.008 \\
\hline & & Level & 6.783 & 0.003 \\
\hline & & Gender*Level & 0.411 & 0.665 \\
\hline \multirow{3}{*}{6} & \multirow{3}{*}{ Lack of motivation to learn science } & Gender & 0.684 & 0.413 \\
\hline & & Level & 3.355 & 0.044 \\
\hline & & Gender*Level & 0.695 & 0.505 \\
\hline \multirow{3}{*}{7} & \multirow{3}{*}{$\begin{array}{l}\text { Nonparticipation in classroom science } \\
\text { activities and labs }\end{array}$} & Gender & 0.334 & 0.566 \\
\hline & & Level & 4.944 & 0.012 \\
\hline & & Gender*Level & 0.516 & 0.601 \\
\hline \multirow{3}{*}{8} & \multirow{3}{*}{$\begin{array}{l}\text { Attempts of cheating during tests or } \\
\text { examinations }\end{array}$} & Gender & 1.137 & 0.292 \\
\hline & & Level & 10.816 & 0 \\
\hline & & Gender*Level & 0.914 & 0.409 \\
\hline \multirow{3}{*}{9} & \multirow{3}{*}{$\begin{array}{l}\text { Students are chatting among themselves during } \\
\text { science class }\end{array}$} & Gender & 0.251 & 0.619 \\
\hline & & Level & 5.161 & 0.01 \\
\hline & & Gender*Level & 2.547 & 0.09 \\
\hline \multirow{3}{*}{10} & \multirow{3}{*}{ Students interrupt others } & Gender & 0.004 & 0.949 \\
\hline & & Level & 4.689 & 0.014 \\
\hline & & Gender*Level & 5.008 & 0.011 \\
\hline \multirow{3}{*}{11} & \multirow{3}{*}{ Excessive absences } & Gender & 1.551 & 0.22 \\
\hline & & Level & 4.317 & 0.02 \\
\hline & & Gender*Level & 1.023 & 0.368 \\
\hline \multirow{3}{*}{12} & \multirow{3}{*}{ Students come late to science lessons } & Gender & 1.63 & 0.209 \\
\hline & & Level & 5.161 & 0.01 \\
\hline & & Gender*Level & 2.354 & 0.107 \\
\hline \multirow{3}{*}{13} & \multirow{3}{*}{ Sleeping during science lessons } & Gender & 0.002 & 0.967 \\
\hline & & Level & 12.438 & 0 \\
\hline & & Gender*Level & 1.822 & 0.174 \\
\hline \multirow{3}{*}{14} & \multirow{3}{*}{ Leaving class early } & Gender & 0.179 & 0.674 \\
\hline & & Level & 4.87 & 0.012 \\
\hline & & Gender*Level & 1.047 & 0.36 \\
\hline \multirow[b]{2}{*}{15} & \multirow{2}{*}{$\begin{array}{l}\text { Playing and using mobile phones during science } \\
\text { class }\end{array}$} & Gender & 0.137 & 0.713 \\
\hline & & Level & 7.691 & 0.001 \\
\hline
\end{tabular}




\begin{tabular}{|c|c|c|c|c|}
\hline $\mathbf{N}$ & Challenges & Factors & $\mathbf{F}$ & P-value \\
\hline & & Gender*Level & 2.036 & 0.143 \\
\hline \multirow{3}{*}{16} & \multirow{3}{*}{$\begin{array}{l}\text { Students reply to the teacher in the impolite } \\
\text { manner }\end{array}$} & Gender & 0.001 & 0.976 \\
\hline & & Level & 3.565 & 0.037 \\
\hline & & Gender*Level & 1.913 & 0.16 \\
\hline \multirow{3}{*}{17} & \multirow{3}{*}{ Harassment and abuse of other students } & Gender & 0.026 & 0.872 \\
\hline & & Level & 8.678 & 0.001 \\
\hline & & Gender*Level & 1.907 & 0.161 \\
\hline \multirow{3}{*}{18} & \multirow{3}{*}{ Inappropriate out of seat behavioral } & Gender & 0.303 & 0.585 \\
\hline & & Level & 6.123 & 0.005 \\
\hline & & Gender*Level & 0.211 & 0.81 \\
\hline \multirow{3}{*}{19} & \multirow{3}{*}{$\begin{array}{l}\text { Students do not complete science assignments } \\
\text { on time }\end{array}$} & Gender & 0.141 & 0.709 \\
\hline & & Level & 2.062 & 0.14 \\
\hline & & Gender*Level & 0.225 & 0.8 \\
\hline \multirow{3}{*}{20} & \multirow{3}{*}{$\begin{array}{l}\text { Lack of concern in performance of science } \\
\text { activities and homework }\end{array}$} & Gender & 0.697 & 0.408 \\
\hline & & Level & 2.809 & 0.071 \\
\hline & & Gender*Level & 0.006 & 0.994 \\
\hline
\end{tabular}

ANOVA results suggest that there was a significant main effect for new science teacher gender $(p=0.008)$ and teacher school level $(p=0.0003)$ when working with students who ignore teachers' instructions, orders and comments. In contrast to their male colleagues, women science teachers perceived the fact that students are ignoring their instructions, orders and comments as a major challenge.

The 2x3 ANOVA also show a significant main effect for new science teacher school level for all challenges except for : students not doing homework on time and lack of concern in performance of science activities and homework. There was a significant interaction effect between new science teacher gender and new science teacher school level when teachers are keeping students form interrupting each other $(p=0.011)$. As compared to teachers in 
elementary and high schools, female science teachers in middle schools gave higher ranking to the challenge related to interruptions when students are speaking in their classrooms.

\section{Interaction Effects for the Factors Years of Experience and School Level}

Third, the interaction effects between new science teacher experience and new science teacher school level on the level of behavioral classroom challenges were investigated. Table 25 shows the means and standard deviations for new science teacher experience and new science teacher school level.

Table 25: Interactions between two factors: Experience and School Level

\begin{tabular}{|c|c|c|c|c|c|}
\hline $\mathbf{N}$ & Challenges & Experience & Level & Mean & $\begin{array}{l}\text { standard } \\
\text { deviation }\end{array}$ \\
\hline \multirow{9}{*}{1} & \multirow{9}{*}{$\begin{array}{l}\text { Students do not appear } \\
\text { ready to learn science }\end{array}$} & \multirow{3}{*}{ First-year } & High School & 3 & 1.09 \\
\hline & & & Middle School & 1 & 0 \\
\hline & & & Elementary School & & \\
\hline & & \multirow{3}{*}{ Second-year } & High School & 2 & 1.15 \\
\hline & & & Middle School & 1 & 0 \\
\hline & & & Elementary School & & \\
\hline & & \multirow{3}{*}{ Third-year } & High School & 2.15 & 0.99 \\
\hline & & & Middle School & 1.69 & 0.85 \\
\hline & & & Elementary School & 3.33 & 1.03 \\
\hline \multirow{9}{*}{2} & \multirow{9}{*}{$\begin{array}{l}\text { Students have negative } \\
\text { ideas about science } \\
\text { lessons }\end{array}$} & \multirow{3}{*}{ First-year } & High School & 2.83 & 1.6 \\
\hline & & & Middle School & 1 & 0 \\
\hline & & & Elementary School & & \\
\hline & & \multirow{3}{*}{ Second-year } & High School & 2.57 & 1.27 \\
\hline & & & Middle School & 2.5 & 0.71 \\
\hline & & & Elementary School & & \\
\hline & & \multirow{3}{*}{ Third-year } & High School & 2.15 & 1.14 \\
\hline & & & Middle School & 1.69 & 0.75 \\
\hline & & & Elementary School & 3.67 & 1.03 \\
\hline & \multirow{2}{*}{$\begin{array}{l}\text { Indifference to science } \\
\text { lessons }\end{array}$} & \multirow{2}{*}{ First-year } & High School & 2.5 & 1.05 \\
\hline & & & Middle School & 2 & 1.41 \\
\hline
\end{tabular}




\begin{tabular}{|c|c|c|c|c|c|}
\hline $\mathbf{N}$ & Challenges & Experience & Level & Mean & $\begin{array}{l}\text { standard } \\
\text { deviation }\end{array}$ \\
\hline \multirow{7}{*}{3} & & & Elementary School & & \\
\hline & & \multirow{3}{*}{ Second-year } & High School & 2.14 & 1.35 \\
\hline & & & Middle School & 1 & 0 \\
\hline & & & Elementary School & & \\
\hline & & \multirow{3}{*}{ Third-year } & High School & 2.15 & 1.14 \\
\hline & & & Middle School & 1.69 & 0.85 \\
\hline & & & Elementary School & 3.33 & 1.21 \\
\hline \multirow{9}{*}{4} & \multirow{9}{*}{$\begin{array}{l}\text { Students do not have } \\
\text { correct supplies ready }\end{array}$} & \multirow{3}{*}{ First-year } & High School & 2.5 & 1.05 \\
\hline & & & Middle School & 2 & 1.41 \\
\hline & & & Elementary School & & \\
\hline & & \multirow{3}{*}{ Second-year } & High School & 2.43 & 1.27 \\
\hline & & & Middle School & 1.5 & 0.71 \\
\hline & & & Elementary School & & \\
\hline & & \multirow{3}{*}{ Third-year } & High School & 2.15 & 0.9 \\
\hline & & & Middle School & 1.69 & 0.75 \\
\hline & & & Elementary School & 4 & 1.1 \\
\hline \multirow{9}{*}{5} & \multirow{9}{*}{$\begin{array}{l}\text { Students ignore the } \\
\text { teacher instructions, } \\
\text { orders and their } \\
\text { comments }\end{array}$} & \multirow{3}{*}{ First-year } & High School & 3.5 & 1.05 \\
\hline & & & Middle School & 1.5 & 0.71 \\
\hline & & & Elementary School & & \\
\hline & & \multirow{3}{*}{ Second-year } & High School & 2.71 & 1.5 \\
\hline & & & Middle School & 2.5 & 0.71 \\
\hline & & & Elementary School & & \\
\hline & & \multirow{3}{*}{ Third-year } & High School & 2.15 & 0.99 \\
\hline & & & Middle School & 1.84 & 1.34 \\
\hline & & & Elementary School & 3.83 & 0.75 \\
\hline \multirow{9}{*}{6} & \multirow{9}{*}{$\begin{array}{l}\text { Lack of motivation to } \\
\text { learn science }\end{array}$} & \multirow{3}{*}{ First-year } & High School & 3.33 & 1.21 \\
\hline & & & Middle School & 1.5 & 0.71 \\
\hline & & & Elementary School & & \\
\hline & & \multirow{3}{*}{ Second-year } & High School & 3.14 & 1.21 \\
\hline & & & Middle School & 2.5 & 0.71 \\
\hline & & & Elementary School & & \\
\hline & & \multirow{3}{*}{ Third-year } & High School & 2 & 0.82 \\
\hline & & & Middle School & 1.69 & 1.18 \\
\hline & & & Elementary School & 3 & 1.41 \\
\hline & Nonparticipation in & First-year & High School & 3.17 & 1.17 \\
\hline
\end{tabular}




\begin{tabular}{|c|c|c|c|c|c|}
\hline $\mathbf{N}$ & Challenges & Experience & Level & Mean & $\begin{array}{l}\text { standard } \\
\text { deviation }\end{array}$ \\
\hline \multirow{8}{*}{7} & \multirow{8}{*}{$\begin{array}{l}\text { classroom science } \\
\text { activities and labs }\end{array}$} & & Middle School & 1 & 0 \\
\hline & & & Elementary School & & \\
\hline & & \multirow{3}{*}{ Second-year } & High School & 3.14 & 1.35 \\
\hline & & & Middle School & 1.5 & 0.71 \\
\hline & & & Elementary School & & \\
\hline & & \multirow{3}{*}{ Third-year } & High School & 2.54 & 1.2 \\
\hline & & & Middle School & 1.85 & 1.28 \\
\hline & & & Elementary School & 2.38 & 1.33 \\
\hline \multirow{9}{*}{8} & \multirow{9}{*}{$\begin{array}{l}\text { Attempts of cheating } \\
\text { during tests or } \\
\text { examinations }\end{array}$} & \multirow{3}{*}{ First-year } & High School & 2.83 & 1.6 \\
\hline & & & Middle School & 2 & 1.41 \\
\hline & & & Elementary School & & \\
\hline & & \multirow{3}{*}{ Second-year } & High School & 2.57 & 1.51 \\
\hline & & & Middle School & 1 & 0 \\
\hline & & & Elementary School & & \\
\hline & & \multirow{3}{*}{ Third-year } & High School & 2.46 & 1.33 \\
\hline & & & Middle School & 1.54 & 0.97 \\
\hline & & & Elementary School & 4 & 0.63 \\
\hline \multirow{9}{*}{9} & \multirow{9}{*}{$\begin{array}{l}\text { Students are chatting } \\
\text { among themselves } \\
\text { during science class }\end{array}$} & \multirow{3}{*}{ First-year } & High School & 3.17 & 0.98 \\
\hline & & & Middle School & 1.5 & 0.71 \\
\hline & & & Elementary School & & \\
\hline & & \multirow{3}{*}{ Second-year } & High School & 2.71 & 1.5 \\
\hline & & & Middle School & 1.5 & 0.71 \\
\hline & & & Elementary School & & \\
\hline & & \multirow{3}{*}{ Third-year } & High School & 2.39 & 1.5 \\
\hline & & & Middle School & 1.92 & 1.32 \\
\hline & & & Elementary School & 3.67 & 1.03 \\
\hline \multirow{9}{*}{10} & \multirow{9}{*}{ Students interrupt others } & \multirow{3}{*}{ First-year } & High School & 3.5 & 1.05 \\
\hline & & & Middle School & 2.5 & 2.12 \\
\hline & & & Elementary School & & \\
\hline & & \multirow{3}{*}{ Second-year } & High School & 3 & 1.53 \\
\hline & & & Middle School & 2 & 0 \\
\hline & & & Elementary School & & \\
\hline & & \multirow{3}{*}{ Third-year } & High School & 2.23 & 1.17 \\
\hline & & & Middle School & 1.93 & 1.26 \\
\hline & & & Elementary School & 3.67 & 1.03 \\
\hline
\end{tabular}




\begin{tabular}{|c|c|c|c|c|c|}
\hline $\mathbf{N}$ & Challenges & Experience & Level & Mean & $\begin{array}{l}\text { standard } \\
\text { deviation }\end{array}$ \\
\hline \multirow{9}{*}{11} & \multirow{9}{*}{ Excessive absences } & \multirow{3}{*}{ First-year } & High School & 1.67 & 0.82 \\
\hline & & & Middle School & 1 & 0 \\
\hline & & & Elementary School & & \\
\hline & & \multirow{3}{*}{ Second-year } & High School & 2.43 & 1.4 \\
\hline & & & Middle School & 2 & 0 \\
\hline & & & Elementary School & & \\
\hline & & \multirow{3}{*}{ Third-year } & High School & 1.15 & 0.55 \\
\hline & & & Middle School & 1.61 & 1.12 \\
\hline & & & Elementary School & 2.83 & 1.17 \\
\hline \multirow{9}{*}{12} & \multirow{9}{*}{$\begin{array}{l}\text { Students come late to } \\
\text { science lessons }\end{array}$} & \multirow{3}{*}{ First-year } & High School & 2.67 & 1.21 \\
\hline & & & Middle School & 2 & 1.41 \\
\hline & & & Elementary School & & \\
\hline & & \multirow{3}{*}{ Second-year } & High School & 3.14 & 1.21 \\
\hline & & & Middle School & 2.5 & 0.71 \\
\hline & & & Elementary School & & \\
\hline & & \multirow{3}{*}{ Third-year } & High School & 2.1 & 1.04 \\
\hline & & & Middle School & 1.85 & 1.46 \\
\hline & & & Elementary School & 3.67 & 0.52 \\
\hline \multirow{9}{*}{13} & \multirow{9}{*}{$\begin{array}{l}\text { Sleeping during science } \\
\text { lessons }\end{array}$} & \multirow{3}{*}{ First-year } & High School & 3.33 & 1.03 \\
\hline & & & Middle School & 1.5 & 0.71 \\
\hline & & & Elementary School & & \\
\hline & & \multirow{3}{*}{ Second-year } & High School & 3.29 & 1.11 \\
\hline & & & Middle School & 3.5 & 0.71 \\
\hline & & & Elementary School & & \\
\hline & & \multirow{3}{*}{ Third-year } & High School & 3.38 & 1.39 \\
\hline & & & Middle School & 1.85 & 1.14 \\
\hline & & & Elementary School & 4.33 & 0.52 \\
\hline \multirow{8}{*}{14} & \multirow{8}{*}{ Leaving class early } & \multirow{3}{*}{ First-year } & High School & 3.5 & 1.52 \\
\hline & & & Middle School & 2.5 & 2.12 \\
\hline & & & Elementary School & & \\
\hline & & \multirow{3}{*}{ Second-year } & High School & 3.43 & 1.52 \\
\hline & & & Middle School & 2.5 & 0.71 \\
\hline & & & Elementary School & & \\
\hline & & \multirow{2}{*}{ Third-year } & High School & 3.46 & 1.27 \\
\hline & & & Middle School & 2.54 & 1.51 \\
\hline
\end{tabular}




\begin{tabular}{|c|c|c|c|c|c|}
\hline $\mathbf{N}$ & Challenges & Experience & Level & Mean & $\begin{array}{l}\text { standard } \\
\text { deviation }\end{array}$ \\
\hline & & & Elementary School & 4.33 & 0.52 \\
\hline \multirow{9}{*}{15} & \multirow{9}{*}{$\begin{array}{l}\text { Playing and using } \\
\text { mobile phones during } \\
\text { science class }\end{array}$} & \multirow{3}{*}{ First-year } & High School & 3.83 & 0.98 \\
\hline & & & Middle School & 2 & 1.41 \\
\hline & & & Elementary School & & \\
\hline & & \multirow{3}{*}{ Second-year } & High School & 3.86 & 1.35 \\
\hline & & & Middle School & 3.5 & 2.12 \\
\hline & & & Elementary School & & \\
\hline & & \multirow{3}{*}{ Third-year } & High School & 3.85 & 1.57 \\
\hline & & & Middle School & 2.5 & 1.56 \\
\hline & & & Elementary School & 4.8 & 0.41 \\
\hline \multirow{9}{*}{16} & \multirow{9}{*}{$\begin{array}{l}\text { Students reply to the } \\
\text { teacher in the impolite } \\
\text { manner }\end{array}$} & \multirow{3}{*}{ First-year } & High School & 4 & 0.89 \\
\hline & & & Middle School & 2.5 & 2.12 \\
\hline & & & Elementary School & & \\
\hline & & \multirow{3}{*}{ Second-year } & High School & 4 & 1.53 \\
\hline & & & Middle School & 1.5 & 0.71 \\
\hline & & & Elementary School & & \\
\hline & & \multirow{3}{*}{ Third-year } & High School & 3.15 & 1.72 \\
\hline & & & Middle School & 2.61 & 1.61 \\
\hline & & & Elementary School & 4.17 & 1.33 \\
\hline \multirow{9}{*}{17} & \multirow{9}{*}{$\begin{array}{l}\text { Harassment and abuse } \\
\text { of other students }\end{array}$} & \multirow{3}{*}{ First-year } & High School & 4.17 & 0.98 \\
\hline & & & Middle School & 1.5 & 0.71 \\
\hline & & & Elementary School & & \\
\hline & & \multirow{3}{*}{ Second-year } & High School & 4.43 & 0.53 \\
\hline & & & Middle School & 2 & 0 \\
\hline & & & Elementary School & & \\
\hline & & \multirow{3}{*}{ Third-year } & High School & 3.85 & 1.57 \\
\hline & & & Middle School & 2.69 & 1.6 \\
\hline & & & Elementary School & 4.33 & 1.03 \\
\hline \multirow{7}{*}{18} & \multirow{7}{*}{$\begin{array}{l}\text { Inappropriate out of seat } \\
\text { behavioral }\end{array}$} & \multirow{3}{*}{ First-year } & High School & 3.67 & 1.03 \\
\hline & & & Middle School & 1 & 0 \\
\hline & & & Elementary School & & \\
\hline & & \multirow{3}{*}{ Second-year } & High School & 3.29 & 1.38 \\
\hline & & & Middle School & 2 & 0 \\
\hline & & & Elementary School & & \\
\hline & & Third-year & High School & 2.92 & 1.66 \\
\hline
\end{tabular}




\begin{tabular}{|c|c|c|c|c|c|}
\hline $\mathbf{N}$ & Challenges & Experience & Level & Mean & $\begin{array}{l}\text { standard } \\
\text { deviation }\end{array}$ \\
\hline & & & Middle School & 2.23 & 1.24 \\
\hline & & & Elementary School & 4 & 0.89 \\
\hline \multirow{9}{*}{19} & \multirow{9}{*}{$\begin{array}{l}\text { Students do not } \\
\text { complete science } \\
\text { assignments on time }\end{array}$} & \multirow{3}{*}{ First-year } & High School & 3.17 & 1.47 \\
\hline & & & Middle School & 1.5 & 0.71 \\
\hline & & & Elementary School & & \\
\hline & & \multirow{3}{*}{ Second-year } & High School & 3.57 & 1.4 \\
\hline & & & Middle School & 2 & 1.41 \\
\hline & & & Elementary School & & \\
\hline & & \multirow{3}{*}{ Third-year } & High School & 2.38 & 1.61 \\
\hline & & & Middle School & 2.15 & 1.14 \\
\hline & & & Elementary School & 3.17 & 0.75 \\
\hline \multirow{9}{*}{20} & \multirow{9}{*}{$\begin{array}{l}\text { Lack of concern in } \\
\text { performance of science } \\
\text { activities and homework }\end{array}$} & \multirow{3}{*}{ First-year } & High School & 3 & 0.89 \\
\hline & & & Middle School & 1 & 0 \\
\hline & & & Elementary School & & \\
\hline & & \multirow{3}{*}{ Second-year } & High School & 3.86 & 1.46 \\
\hline & & & Middle School & 2 & 1.41 \\
\hline & & & Elementary School & & \\
\hline & & \multirow{3}{*}{ Third-year } & High School & 2 & 1.35 \\
\hline & & & Middle School & 2.23 & 1.09 \\
\hline & & & Elementary School & 3.5 & 0.55 \\
\hline
\end{tabular}

Table 25 shows that the lowest mean value of level of behavioral challenges occurred for middle school science teachers in their first year of teaching $($ mean $=1)$. These science teachers were able to identify the top 6 major challenges $($ mean $=1)$ they are facing in their profession: teachers absenteeism, negative ideas about science, inappropriate out of seat behavior, indifference to their science classroom performance, absence of participation in science activities and labs and lack of readiness to learn science. The top three major challenges with mean $=1$ for second-year middle school science teachers, were: indifference to science lessons, 
student cheating on examinations and tests and lack of readiness to learn science. For third year science teachers at middle schools, student cheating on examinations and tests (mean $=1.54$ ), student absenteeism $($ mean $=1.61)$ and lack of readiness to learn science $($ mean $=1.69)$ were their three biggest challenges.

First-year science teachers in high schools gave significantly higher challenge seriousness ratings for student absenteeism $($ mean $=1.67)$, indifference to science lessons $($ mean $=2.5)$ and inappropriate school supplies $($ mean $=2.5)$. For second-year science teachers in high schools, a lack of readiness to learn science $($ mean $=2)$ and indifference to science lessons $($ mean $=2.14)$ were their major challenges. In addition to student absenteeism $($ mean $=1.15)$, third year science teachers in high schools identified student lack of motivation $($ mean $=2)$, indifference to their science classroom performance $($ mean $=2)$ and lateness to science lessons as their biggest challenges (mean $=2.1)$. In elementary schools, third year teachers encountered the following major challenges in their classroom: nonparticipation in science activities and labs $($ mean $=2.38)$, student absenteeism $($ mean $=2.83)$ and lack of motivation $($ mean $=3)$.

Table 26 exhibits the output of a two-way ANOVA analysis and whether there was a significant interaction effect between new science teacher experience and their school level on the level of behavioral challenges that they encountered in their classroom. 
Table 26: Significance of Interactions between two factors: Experience and School Level

\begin{tabular}{|c|c|c|c|c|}
\hline $\mathbf{N}$ & Challenges & Factors & $\mathbf{F}$ & P-value \\
\hline \multirow{3}{*}{1} & \multirow{3}{*}{$\begin{array}{l}\text { Students do not appear ready to learn } \\
\text { science }\end{array}$} & experience & 0.541 & 0.586 \\
\hline & & Level & 9.437 & 0 \\
\hline & & experience*Level & 1.565 & 0.221 \\
\hline \multirow{3}{*}{2} & \multirow{3}{*}{$\begin{array}{l}\text { Students have negative ideas about } \\
\text { science lessons }\end{array}$} & experience & 0.811 & 0.451 \\
\hline & & Level & 7.702 & 0.001 \\
\hline & & experience*Level & 1.173 & 0.319 \\
\hline \multirow{3}{*}{3} & \multirow{3}{*}{ Indifference to science lessons } & experience & 0.59 & 0.559 \\
\hline & & Level & 5.327 & 0.009 \\
\hline & & experience*Level & 0.249 & 0.781 \\
\hline \multirow{3}{*}{4} & \multirow{3}{*}{$\begin{array}{l}\text { Students do not have correct supplies } \\
\text { ready }\end{array}$} & experience & 0.273 & 0.762 \\
\hline & & Level & 12.27 & 0 \\
\hline & & experience* Level & 0.145 & 0.866 \\
\hline \multirow{3}{*}{5} & \multirow{3}{*}{$\begin{array}{l}\text { Students ignore the teacher instructions, } \\
\text { orders and their comments }\end{array}$} & experience & 0.969 & 0.388 \\
\hline & & Level & 7.754 & 0.001 \\
\hline & & experience*Level & 1.388 & 0.261 \\
\hline \multirow{3}{*}{6} & \multirow{3}{*}{ Lack of motivation to learn science } & experience & 2.229 & 0.12 \\
\hline & & Level & 4.764 & 0.014 \\
\hline & & experience*Level & 1.148 & 0.327 \\
\hline \multirow{3}{*}{7} & \multirow{3}{*}{$\begin{array}{l}\text { Nonparticipation in classroom science } \\
\text { activities and labs }\end{array}$} & experience & 0.057 & 0.944 \\
\hline & & Level & 6.068 & 0.005 \\
\hline & & experience*Level & 1.064 & 0.354 \\
\hline \multirow{3}{*}{8} & \multirow{3}{*}{$\begin{array}{l}\text { Attempts of cheating during tests or } \\
\text { examinations }\end{array}$} & experience & 0.431 & 0.653 \\
\hline & & Level & 9.021 & 0.001 \\
\hline & & experience*Level & 0.195 & 0.823 \\
\hline \multirow{3}{*}{9} & \multirow{3}{*}{$\begin{array}{l}\text { Students are chatting among themselves } \\
\text { during science class }\end{array}$} & experience & 0.055 & 0.946 \\
\hline & & Level & 5.436 & 0.008 \\
\hline & & experience* Level & 0.617 & 0.545 \\
\hline \multirow{3}{*}{10} & \multirow{3}{*}{ Students interrupt others } & experience & 1.457 & 0.244 \\
\hline & & Level & 5.191 & 0.01 \\
\hline & & experience*Level & 0.324 & 0.725 \\
\hline \multirow{3}{*}{11} & \multirow{3}{*}{ Excessive absences } & experience & 1.902 & 0.162 \\
\hline & & Level & 5.427 & 0.008 \\
\hline & & experience*Level & 1.111 & 0.339 \\
\hline
\end{tabular}




\begin{tabular}{|c|c|c|c|c|}
\hline $\mathbf{N}$ & Challenges & Factors & $\mathbf{F}$ & P-value \\
\hline \multirow{3}{*}{12} & \multirow{3}{*}{ Students come late to science lessons } & experience & 1.406 & 0.256 \\
\hline & & Level & 5.657 & 0.007 \\
\hline & & experience*Level & 0.134 & 0.875 \\
\hline \multirow{3}{*}{13} & \multirow{3}{*}{ Sleeping during science lessons } & experience & 1.423 & 0.252 \\
\hline & & Level & 8.265 & 0.001 \\
\hline & & experience*Level & 1.701 & 0.195 \\
\hline \multirow{3}{*}{14} & \multirow{3}{*}{ Leaving class early } & experience & 0.002 & 0.998 \\
\hline & & Level & 3.829 & 0.03 \\
\hline & & experience*Level & 0.002 & 0.998 \\
\hline \multirow{3}{*}{15} & \multirow{3}{*}{$\begin{array}{l}\text { Playing and using mobile phones during } \\
\text { science class }\end{array}$} & experience & 0.481 & 0.621 \\
\hline & & Level & 5.507 & 0.008 \\
\hline & & experience*Level & 0.454 & 0.638 \\
\hline \multirow{3}{*}{16} & \multirow{3}{*}{$\begin{array}{l}\text { Students reply to the teacher in the } \\
\text { impolite manner }\end{array}$} & experience & 0.184 & 0.832 \\
\hline & & Level & 4.704 & 0.014 \\
\hline & & experience*Level & 1.12 & 0.336 \\
\hline \multirow{3}{*}{17} & \multirow{3}{*}{ Harassment and abuse of other students } & experience & 0.268 & 0.766 \\
\hline & & Level & 9.285 & 0 \\
\hline & & experience*Level & 1.173 & 0.319 \\
\hline \multirow{3}{*}{18} & \multirow{3}{*}{ Inappropriate out of seat behavioral } & experience & 0.103 & 0.902 \\
\hline & & Level & 7.18 & 0.002 \\
\hline & & experience*Level & 1.405 & 0.257 \\
\hline \multirow{3}{*}{19} & \multirow{3}{*}{$\begin{array}{l}\text { Students do not complete science } \\
\text { assignments on time }\end{array}$} & experience & 0.379 & 0.687 \\
\hline & & Level & 3.418 & 0.042 \\
\hline & & experience*Level & 1.127 & 0.333 \\
\hline \multirow{3}{*}{20} & \multirow{3}{*}{$\begin{array}{l}\text { Lack of concern in performance of } \\
\text { science activities and homework }\end{array}$} & experience & 1.37 & 0.265 \\
\hline & & Level & 6.794 & 0.003 \\
\hline & & experience*Level & 3.593 & 0.036 \\
\hline
\end{tabular}

ANOVA results indicated that, for all challenges there was a significant main effect for new science teacher school level. No significant main effect was found for new science teacher experience. The two-way ANOVA also showed that there was a significant interaction effect between new science teacher school level and new science teacher experience for the challenge 
related to student indifference to their performance in science activities and homework $(\mathrm{p}=0.036)$. As compared to their second and third years science teacher colleagues in elementary and high schools, the first year science teacher in middle schools perceived student indifference to their performance in science activities and homework as a major challenge in their classrooms. 


\section{Research Question 3 - New science teachers' beliefs and supports}

New science teachers encounter numerous challenges in their pursuit of effective science teaching practices. To better support new science teachers, it is necessary to better understand and determine their beliefs about effective science teaching because teachers' beliefs influence the manner that teachers frame and implement their classroom teaching practices.

The findings presented here highlight the views, perceptions and beliefs about effective science teaching and illustrate the amount of support they receive in their teaching practice. First, each of the new science teacher explained their beliefs about effective science teaching. Second, new science teachers evaluated the frequency and quality of support that they receive in relation to their teaching practices.

\section{New science teachers' conceptions of effective science teaching}

The nine beginning science teachers involved in the interviews expressed and shared their views about effective science teaching practices through interviews. To capture the views, perceptions and beliefs of the new science teachers have about effective science teaching, the characteristics of effective science teaching were grouped in five categories. These categories involved:

(a) Identify and teach the core scientific ideas, (b) connecting science content with students' interests and real life issues, (c) using inquiry practices and getting hands on experiences, (d) Cooperative and collaborative learning, (e) providing students with feedback by using multiple assessment methods .

\section{Identify and teach the core scientific ideas}

Two of the new science teachers, Maryam and Khalid perceived the traditional teaching method as particularly important in science teaching. They both teach science as a sequence of 
lectures and recitations followed by some reading assignments, end-of chapter problem solving, and laboratory activities. Maryam expressed her opinion about the effectiveness of traditional methodology:

I often think about the most important thing in my science class. My question to this answer is to identify and teach the core scientific ideas to my students using structured lectures as a primary mode of instruction. I begin the lecture by introducing science topics, then organizing concepts, summarizing the main points of a given lesson and clarifying difficult concepts. I spend more time presenting meaningful and relevant science concepts and also providing the opportunity to my students to really engage with these concepts. To capture and hold students' attention, I make lectures in the classrooms more dynamic and interactive. I delivered my lectures in such way that students actively participate to the learning activity and remember critical information of science lessons. The use of lecture-explanation techniques promote students active engagement by fostering enthusiasm and a motivation for learning, stimulating further learning and thinking and challenging problem solving skills. Lecture as a model of teaching is an effective way for teaching science.

This opinion is supported by Khalid who stated that:

In my science classroom, I usually teach my student by giving to them an oral presentation of important science concepts, facts and principles followed by some short activities for students such as problem solving, answering student questions or classroom discussions. I always try not only to provide a good coverage of a topic but also to generate student interest and understanding. When planning for my lesson, most of the time is devoted to organizing the lecture structure and presentation in order to make my lessons simple, fun and excited for my students. Telling students about a science topic can promote their enthusiasm for learning science and capture their imagination.

Maryam and Khalid beliefs regarding science teaching and learning were well-aligned with the results of Kauchack and Eggen (1988) studies. In their studies, Kauchack and Eggen concluded that lecture model of teaching is still the most common method of teaching in different subjects because it is an easy, flexible and efficient style of teaching.

\section{Connecting science content with students' interests and real life issues}

As a new science teacher, Ibrahim had his own ideas about what it means to be a highly effective science teacher. He thinks that effective science teachers always employ a variety of methods to connect the content of science instruction to the student's prior knowledge, student 
interests and the real world applications. Ibrahim shared these thoughts and views during the interview:

I strongly believe that science should not be taught as a stand-alone subject but must be taught as a subject that is connected to other subject areas and real life. Therefore, I am doing my best to establish a link between what we are studying in my science classroom and the real world events, concerns, issues and problems as well as other subjects. In my opinion, students learn effectively when they can see and understand the connections between their science lessons and the world beyond school walls. To ensure that my students understand and recognize the relevance of their science classroom lessons, I make them work on a science project based on their interests and the appropriateness of the topic. In each project, students make and record scientific observations, collect and analyze data, organize their ideas and propose explanations. Students also explore and integrate knowledge and mode of thinking from different disciplines in their science projects. I help the students go through each step of the scientific process and do the research. The science projects offer opportunities for students to build their scientific skills by applying their scientific knowledge to solve authentic problems in real world situations.

Ibrahim's views on effective science teaching were consistent with the findings of Holubova's (2008) research. In her work, Holubova described project-based science teaching as one of the best way to effectively teach science for facilitating student learning and understanding.

\section{Using inquiry practices and getting hands-on experiences}

The preferred method for teaching science for four of the teachers: Leila, Fatimah, Ali and Kareem was to allow their students to explore science ideas, concepts and principles through scientific experiments and laboratories. Although all four science teachers highly prioritized the use of inquiry strategies and experiments, they have various interpretations of what teaching science through experience means.

Fatimah and Ali used a variety of approaches in which their students observe and actively think about a scientific concept and then move into the experimental process to explain the concept. Fatimah described her inquiry strategy during the interview:

I try to start my science lesson with something that is short and interesting to capture students' attention, mentally engage them and stimulate their thinking. Students were 
provided an opportunity to think, talk, ask a variety of question about a science concept and also connect what they already know with new learning. The students use hands-on activities to develop an understanding of the new science concept. After students have explored the concept, I present the concept to them and help them answer questions that they have about the concept. Students apply information or knowledge about the new science concept to new situations and I guide them toward a deeper understanding of the concept. To assess student comprehension and academic progress, I usually ask my students open ended questions and also give them a test or quiz on the newly introduced concept. As a science teacher, I also give effective learning feedback to my students in a timely manner. Teaching science as an inquiry provides the opportunity for students to understand science concepts by themselves and the responsibility of learning remains with them.

Leila and Kareem teach science students by providing opportunities for their students to design and carry out experiments which help the students better understand scientific concepts, principles and theories. Kareem described the learning by implementing this methodology (see

Appendix G):

In my science classroom, I use the "learn by doing" approach for teaching my students. When introducing a new science topic, I start by first describing a new experience or activity to the students and then ask them to perform it either individually or in group. After experience or activity completion, students were asked to share among themselves their observations, results and reactions. The results shared by students were analyzed through discussions and looking at the experience. Then, students summarized what they have learned from the experience and formulate the concept. Finally, students were asked to implement or execute what they learned from the experience to similar or different situations. In my opinion, learning by doing method is one of the best methods for teaching science because it provides opportunities for students to enhance and verbalize logical thoughts, develop psychomotor skills, compare experiences, summarize and evaluate their experiences, and utilizes the results in real life environment.

\section{Cooperative and collaborative learning}

To effectively teach science to students, Abdullah favored the cooperative and collaborative learning approach. He expressed his thoughts and experience regarding student learning groups in the science classroom:

Helping students with different abilities, experiences, needs and rates of learning require arranging them into different groups to work together on various science activities. In my science classroom, for group activities, I usually use from three to five students to create a group, then I assign role to students within their groups. To keep students on task 
during group work in the classroom, I circulate around the room while listening, observing and engaging in discussion with each group. During the group-learning activities, students work in team like scientists. They talk to each other, listen to one another, discuss the outcomes of the science activities and arrive at conclusions together. At the end of an experiment or activity, I give the opportunity to each group of students to present their finding to the whole class. Finally, I provide feedback to each group about their team performance. I also make sure that the targeted content or skills are mastered by all team members. In cooperative and collaborative learning environment, high achiever students can improve their understanding of science and lower achiever students get a sense of achievement though contributions to the group-learning activities. All students are actively engaged in the learning process. The participation of a student in a group work in science classroom is a main ingredient in student learning.

Abdullah held the same opinion about effective science teaching approach as Howe (2009, 2013) and Johnson and Johnson (1999). In his studies, Howe (2009, 2013) demonstrated that cooperative learning helps students gain considerable conceptual understanding in science and enhances their reasoning and critical thinking skills. According to Johnson and Johnson (2000), cooperative learning is the best pedagogical practice that can positively increase students' achievements, deepen science understanding and develop interpersonal relationships.

\section{Providing students with feedback by using multiple assessment methods}

Omar highly prioritized the use of multiple assessment methods through effective feedback to ensure that students are learning and to evaluate the effectiveness of a teaching method. He spoke about the assessment strategies that he uses in defining effective science teaching:

Before beginning a new science lesson, I use pretests, graphic organizers and a set of questions to gather information about my students already know about the upcoming concept. Then, using students' prior knowledge, I made final decisions about what and how I am going to teach a concept so that students easily understand it. Assessing student background or prior knowledge is an important element of effective science instruction. During a science lesson instruction, I use quizzes, homework, in class activities and questions and answers sessions to gather information about how well the learning objectives and outcomes of a science lesson are being met. Then, I provide feedback in a clear and practical format to each of my students on demonstrations of learning. I think it 
is very important to give feedback on student learning because it helps me to address areas that require reteaching, inform students about their progress, and improve student learning. After instruction of a science lesson, my students are required to either take a final examination or do a project. This final evaluation provides the opportunity to judge student performance and achievement as well as effectiveness of instructional practices.

In this way, Omar's talk is very much aligned with the assessment strategies framed by Hanna and Dettmer (2004). In their work, Hanna and Dettmer recommended that teachers should increase their focus on the development of a wide variety of assessment strategies to determine students' weaknesses and deficiencies. In addition, the selection of assessment methods should be aligned with the student learning behaviors and outcomes and also the content of the course.

\section{New science teachers' support programs}

In this study, when beginning science teachers were asked a number of questions about the support they received to better fulfill their profession, all of them answered that they get little or no support. All nine new science teachers that I interviewed said that the school administrators did not support them, did not appreciate their work and did not trust their judgements as professionals.

Analyses of the interview participants' comments revealed five areas where schools can provide more or better support and help new science teachers to become competent and effective teachers. These areas are: New teacher orientation programs, mentoring programs, curriculum and lesson planning, classroom management and discipline, and professional development programs.

\section{New teacher orientation programs}

In the Kingdom of Saudi Arabia, most schools have orientation programs and almost all new teachers participate in these orientation programs. However, not all the orientation programs 
are effective to assist new teachers in becoming successful in their profession. An effective

orientation program can help new teachers feel accepted by the school, understand the norms and values of the workplace, interact with colleagues and increase the potential for success of new teachers.

Participants in the study expressed their opinions about the effectiveness of the teacher orientation program at their schools. Almost all of them felt that the orientation programs did not equip them with the skills they need to start the school year. The majority of beginning science teachers believe that the new teacher orientation programs are generally poorly organized, shallow, too short, and do not provide information on effective teaching skills. Moreover, the schools did not seek any feedback from the orientation program participants for improvement of their existing programs. The new teachers still experience feelings of isolation, frustration and failure and also lack of support and help after attending the school orientation training. Abdullah shared his experience and views about new teacher orientation program.

After I was hired as a new science teacher, I participated in my school novice teacher orientation program ahead of start of academic year. During orientation, I was introduced to my new school, the job itself and the academic and administrative members. I was also given a tour of the school and get shown where my office and classrooms are. I was handed out the curriculum for my class and a new teacher orientation booklet with all resources, policies, procedures and expectations. I enjoy most the opportunity to interact with my teacher colleagues and more experienced teachers. It was a very friendly atmosphere within the school. However, the amount of time allowed for new teacher orientation program was not enough. In order for new teachers to succeed, the schools need to put in the time. The teacher orientation program failed to foster instructional development of new teachers. It did not provide opportunity for new teachers to learn effective teaching strategies for creating a positive classroom environment. The new teacher orientation program failed to address any issues related to the use of the curriculum materials and classroom management. Probably the most frustrating thing for me was the total absence of a feedback mechanism to improve the quality of teacher orientation program.

\section{New Teacher Mentoring Programs}

Many schools in Saudi Arabia have not yet established a successful mentoring program 
for science teachers that are new in the profession. Most science teachers with less than three years of experience were not assigned a mentor teacher. In fact, many beginning teachers were left alone in their classroom with no help and little instructional support from their veteran colleagues and principal. In the interview, Khalid expressed his concerns in the following way:

Although beginning and more experienced teachers have a good relationship, my school did not have a mentoring program for new teachers. All staff members at the school make me feel welcomed but I was looking for something more than a friendly greeting and an open door. I had a stressful and hard time in my first year in the classroom. I felt lonely and no one came to help me in my profession because I could not initiate a relationship with my more experienced colleagues. I knew that I could have found support from colleagues with more years of teaching experience. I believe that I have much to learn from experienced teachers. They are invaluable resources that new teachers have to utilize them. Knowledgeable experienced teachers can help new teachers with challenging related to the organization of the instruction, curriculum, classroom and time management, student assessments and dealing with student parents by working side by side and sharing ideas. I strongly urge all schools to adopt a mentoring program because it can help many new teachers to be successful in their workplace.

\section{Curriculum and Lesson Planning}

At the beginning of each academic year, science teachers were handed out science course textbooks and curriculum materials. These instructional materials are helpful and excellent teaching aids for new teachers. However, textbooks and curriculum materials failed to provide a detailed sequence of teaching procedures that tell the beginning science teachers what to teach, when to teach and how to teach it. Sometimes, new science teachers supplement the textbook with lots of outside readings to overcome the limitations of a single textbook. Therefore, they are spending tremendous amount of time preparing science lessons. In fact, new science teachers receive very little help from their school in their attempt to figure out how to plan the science course content. Omar described challenges that he experienced with the curriculum and lesson planning situation. He stated: 
As a novice teacher, I was mandated to teach science courses but I did not receive clear, coherent and detailed curriculum materials about the courses. I spent lot of time outside the classroom preparing and planning a comprehensive lesson plan for class time. The school did not offer support except giving me the course textbooks. In the absence of specified curriculum, I do not only read the appropriate pages of the textbook for a given lesson but also buy and use some instructional materials as a teaching guide. The absence of a content-rich curriculum has not only a detrimental effect on student achievement but also the teacher performance. I would welcome more structural support from my school that would guide me in what to teach and how best to teach science topics or skills.

\section{Classroom Management and Discipline}

New science teachers wrestle with the challenge of delivering engaging instruction to students and at the same time handling poorly-behaved students. All nine new teachers felt frustrated, angry, depressed and anxious while trying to deal with disrespectful and difficult students. The school leadership does not often assist new teachers to better manage classrooms from the start.

Kareem shared these thoughts and perceptions:

I love teaching science and I feel that I am competent and have good subject knowledge. However, I was really struggling with classroom management. I was facing consistent student behavior challenge in my classroom and did not how to deal with the classroom management challenge. I was not able to control my class. It was difficult to achieve learning goals without good student discipline. The school principal often fails to intervene adequately to solve the classroom management issues. He was expected me to handle student discipline problems and was not ready to step in with support. Students with severe misbehaviors and habitual offenses in my class were sent to the office of the principal. After a few days, the defiant and disruptive students repeat their bad behavior in the class. Difficulties in managing classrooms give me feelings of excessive stress and feelings of failure in my profession. New teachers need significant support from the schools to be successful by improving their classroom management practices and skills. Classroom management and discipline is an important component of positive and successful science classroom.

\section{Professional Development Programs}

In Saudi Arabia, many schools have not yet implemented comprehensive in-service training programs to support the growth and development of their new teachers. In fact, during their initial years in the classroom, teachers were not provided the opportunity to learn and 
improve teaching essential skills and competencies, while a set of intensive and structured

professional training programs for beginning science teachers could have enhanced their abilities to teach science effectively to students.

Maryam described her frustration with the lack of opportunities of professional development in her school. She said:

I have taught science for 2 years and did not have the opportunity to attend any professional development activities. I was always assigned the most challenging classes with little supervision and support. To effectively teach my classes, I was looking for a variety of class teaching strategies that I could use to improve student learning. I was not felling supported by my school administrators because they did not provide to me and the teaching staff neither professional workshops nor other organized in-service training programs. Lack of effective professional development programs for teachers is one the more serious obstacles to the successful development of new teachers. Professional development should occur over time and be ongoing, experiential and collaborative in order to improve both teacher practice and student learning.

It is important for novice teachers to receive support that best correspond to their specific needs. The appropriate support provided for new teachers allow them to become more effective and efficient. New science teacher support in different areas such as induction and professional development programs, subject matter knowledge and teacher education programs can help promote career learning and professional development. The results of this study are supported by Wong (2004) study. In his study, Wong (2004) described components of successful induction program: (a) before the first day of a school year, it is important to have 4 or 5 days of induction, (b) offer a systematic training of teachers over a period of 2-3 years, (c) create study groups to help new teachers to build their network, support, commitment and leadership, (d) support provided by school administrators, (e) the induction program must include a mentoring component, (f) provide a structure for modeling effective teaching, and (g) the participants of the induction program are given the opportunity to attend demonstration classrooms.

Furthermore, many studies have shown that new teachers who had participated in a 
comprehensive, high quality and well-designed teacher induction programs tend to better organize their instruction around main scientific ideas and to adapt instruction to the needs of their students (Feiman-Nemser and co., 2000; Fisk, 1997; Feiman-Nemser and co., 1999; Liu and Meyer, 2005). 


\section{Chapter 5: Conclusions and Recommendations}

\section{Summary}

As the Kingdom of Saudi Arabia experiences unprecedented population growth, the government has responded by expanding existing schools and building new schools. Increasing trends in education have led to an increase in the recruitment of new teachers and in the retention of veteran teachers in order to meet the needs of families and children. Certain academic subjects such as science, technology, engineering and mathematics across the kingdom have higher need for teachers than others. In recent years, as part of its ongoing investment in high quality education, the Saudi Arabia government has hired many new science teachers across the country. As new science teachers embark on their teaching careers, they face real challenges in their attempt to become effective science teachers. Numerous studies described several challenges new science teachers encounter in their classroom (Corcoran, 1981; Fuller, 1969; Gold, 1996; Reeves \& Kazelkis, 1985). However, very little of the available research looks specifically at the challenges of science teachers in their first three years of teaching in the Kingdom of Saudi Arabia.

The three main goals of this study were the following: to identify and better understand the academic challenges that new science teachers encounter in their profession in the Kingdom of Saudi Arabia, to investigate the behavioral challenges that novice science teachers faced in the classroom, to examine their beliefs about effective science teaching and their perceptions regarding the support they received. Addressing each of the three goals and objectives of the study, three research questions were raised:

1. What are the academic challenges that new science teachers face in the Kingdom of Saudi Arabia? 
2. What are the behavioral challenges encounter by new science teachers in their classrooms?

3. What are new science teachers' perceptions of effective science teaching and teacher support?

The first two research questions were investigated using quantitative research methods and the last question was evaluated using qualitative methods. The first two research questions involve the collection of the data using various surveys followed by the statistical analysis of the data using SPSS 21.0 software.

For the first question, a survey questionnaire that measured the level of academic teaching challenges faced by new science teachers in the kingdom of Saudi Arabia was used to gather valuable information. The Mann-Whitney test was conducted to determine if there were significant differences between the academic challenges faced by new male and female science teachers. In addition, the Kruskal-Wallis non-parametric analysis of variance test was performed to compare the differences in the academic challenges encountered by new science teachers in their profession among first year, second year and third year new science teachers on one side and among high school, middle school and elementary school new science teachers on the other side.

The second research question also used a survey questionnaire to identify the level of the behavioral challenges that new science teachers encountered in their classrooms. An independent samples T-test was used to determine the significance of the differences in the classroom management challenges between male and female new science teachers. One-way ANOVA was performed to analyze the main effects of new teacher teaching experience and school level separately across the levels of classroom behavioral challenges. The interaction effects among the factors: teaching experience, school level and gender on the classroom behavioral challenges were investigated using three two-way ANOVAs. A 0.05 statistical significance level 
was used for all results obtained by statistical methods.

To address the last question, semi-structured interviews were used to understand new science teacher perceptions of effective science teaching and investigate the quality of support received. All interviews were voice- recorded and fully transcribed into a written form to highlight the main points of each interviewee.

\section{Findings}

\section{Academic Challenges}

Results of this study suggest that the three most important academic challenges faced by new science teachers, who participated in our study, from different gender, different school levels, different grades and different science subjects are: weak teacher preparation program, lacking appropriate school equipment and facility, and shortage of materials and supplies.

The most fundamental academic challenges faced by these new science teachers in Al Jouf was their low level of preparation with regard to science topics. Despite the tremendous effort of the government, the Kingdom of Saudi Arabia still has a higher percentage of poor quality of science teacher training programs. All the study participants felt that they were not prepared to deliver science related subjects instruction effectively because the previous teacher preparation programs they have attended were not teaching what they need to be.

Lacking appropriate school equipment and facility was the second most fundamental academic challenge facing these novice science teachers. They did not have access to science laboratory facilities and libraries in their schools. In some schools, although buildings were erected for science laboratories or libraries, they were not well equipped. In these schools, science teachers do not have access to some of the most commonly used equipment such as balances, beakers, microscopes, pipets, bulbs, thermometers, voltmeter, pulley, connecting leads 
for circuits, gloves and eye protection to ensuring that all science teachers have the opportunity to teach science properly and effectively. Many schools also lack competent and qualified science laboratory workers to carry out and supervise experiments.

The third major academic challenge for beginning science teachers involved in the study was the shortage of school supplies and instructional materials. They have trouble getting from their schools latest books, teaching aids, curriculum materials, printers, projectors, computers and high speed internet those are fundamental for teaching science. Shortages and poor quality of instructional materials create a significant obstacle for new science teachers as they attempt to teach science effectively and meet the needs of their students.

However, the three most important academic challenges faced by novice science teachers in Al Jouf are weak teacher preparation program, lacking appropriate school equipment and facility, and shortage of materials and supplies and did not seem to match the most frequent novice teacher academic challenges reported by much of the research and literature. In fact studies performed by Corcoran (1981), Fuller ( 1969), Gold (1996), Reeves \& Kazelkis (1985); and Veenman (1984) highlighted classroom management, knowledge of administrative routines and procedures, good understanding of a particular school philosophy, building and sustaining relationships with colleagues and parents, strong subject matter knowledge and effective use of instructional, curriculum and assessment materials as major challenges faced by new teachers. Rather, the three most important academic challenges revealed by this study can be linked with Flores and Days' (2006) study. Their work identified teacher pre-service training and the school environment as most influential variables which characterize teacher early years in the profession.

In addition to looking at the broader group of new science teachers in Al Jouf, the 
academic challenges faced by novice science teachers were analyzed by grouping the teachers in our study by gender, school levels and teaching experiences. For the independent variable gender, the results of the rankings of science teaching challenges revealed that both male and female new science teachers have roughly identified similar top two challenges: weak teacher preparation program and lack of appropriate school equipment and facility. Female new science teachers have identified lack of science subject knowledge as a major science teaching challenge and ranked it in the third place, while their male colleagues selected shortage of materials and supplies for the third place. The Mann-Whitney $U$ test conducted for gender on science teaching challenge level showed that male and female new science teachers have significantly different perceptions about the following four academic challenges: (1) awareness of school policies, rules and procedures, (2) opportunity to influence over school decision making, (3) classroom discipline, and (4) knowledge of science subject matter. It should be noted that the differences in results between female and male teachers could be as a result of the gender segregated environment present in the Saudi Arabian school system.

The female new science teachers, who participated in our study, felt that they did not have enough knowledge in science. From their perspective, school administrators did not only explain to them clearly and effectively existing school policies, rules and procedures of school but also did not take into consideration their thoughts, concerns, feelings, emotions and feedback during the decision making procedures. On the other hand, new male science teachers were wrestling more than their female colleagues with challenges related to classroom discipline.

Comparing elementary, middle and high school new science teacher study participants, the findings indicated that the top three academic challenges were ranked in different order of importance. For elementary school beginning science teachers, the top three major academic 
challenges that they encountered were the poor quality of teacher training programs, lack of appropriate school equipment and facility, and the shortage of instructional materials and supplies. Similar top three challenges were encountered by high school beginning science teachers who ranked the lack of appropriate school equipment and facility as their biggest challenge followed by the poor quality of teacher training programs and the shortage of instructional materials and supplies. Like elementary school science teachers, middle school new science teachers perceived the poor quality of teacher training programs and the lack of appropriate school equipment and facility as their top two challenges. Middle school new science teachers ranked the challenge related to the process of assessing student learning level in the third place. The Kruskal-Wallis non-parametric analysis of variance revealed a significant rank order effect for science teacher school levels in seven areas of challenges that faced new science teachers: assessing students' work, determining learning level of students, planning lessons and school days, organization of class work, opportunity to influence over school decision, motivating students, and awareness of school policies, rules and procedures. Planning science lessons and school days, organizing class work, lacking awareness of school policies, rules and procedures and not having the opportunities to influence over school decisions were more challenging for elementary science teachers. In contrast to elementary school teachers, middle and high school new science teachers perceived the process of assessing student learning level and motivating students to learn science as major academic challenges. Like elementary school teachers, high school novice science teachers were struggling to get used to their schools' policies, rules and procedures.

When looking at the teaching experience years of novice science teachers, who participated in the study, findings suggest that there were some differences in teaching challenge 
rankings among first, second and third year science teachers. The top three ranking challenges faced by science teachers during their first year of teaching were: attending weak teacher preparation program, struggling to determine exactly the learning level of students, and lacking science subject matter knowledge. For second-year science teachers, their four biggest challenges were: motivating students to learn science, lacking opportunities for professional growth, having heavy teaching loads, and missing appropriate school equipment and facility. Third-year science teachers gave the highest rankings challenges to the lack of adequate school equipment and facilities, followed by the weakness of teacher preparation programs and shortage of school materials and supplies. The results of the Kruskal-Wallis non-parametric analysis of variance showed that there was a significant difference among first, second and third year science teachers for student science learning motivation challenge.

The results of academic challenges faced by novice science teachers in the present study show no perfect alignment with those obtained by Evans and Tribble (1986). Evans and Tribble indicated in their studies that the teaching problems rankings between male and female teachers were not significant. However, the disparity in perception of teaching problems between elementary and secondary teachers was significant in three areas: classroom discipline, dealing with student individual differences and relationship with colleagues.

\section{Behavioral Challenges}

This study also investigated the classroom behavioral challenges encountered by new science teachers in their classroom. The results indicated that student absenteeism, student lack of readiness to learn science and student indifference to science were the three most behavioral challenges encountered by these novice science teachers in the Al Jouf region.

Excessive student absenteeism was perceived to be the biggest classroom behavioral 
challenge currently facing these new science teachers. This finding suggests that our study participants had a significant number of their students who missed more than two consecutive weeks or 30 days of school over the full academic year. There were several factors contributing to their students absenteeism such as injury or childhood sickness, laziness, mismanagement of time, reliance on others, parental apathy, student and parental educational negligence. Students with poor school attendance are more likely to fail behind in academics.

Student lack of readiness to learn science obtained a second-place rating overall among the classroom behavioral challenges faced by novice science teachers involved in our study. These new science teachers believed that most of their students were lacking prior knowledge about the content of science and do not have the required level to undertake the learning of science. They felt that the majority of their students were struggling to understand the new set of science key concepts and skills because these students failed to master fundamental science concepts and basics in their previous grade.

For the new science teachers, who participated in our study, the third major behavioral challenge was student lack of interest in science mainly due to their student perceptions and beliefs toward science subjects and deficient background knowledge of science concepts. These beginning science teachers felt that most of their students perceived science subjects as too difficult, boring, uninteresting, inappropriate and useless in all walks of life and therefore become convinced that they did not possess the skills and abilities necessary to be good at science. Students, who lack the background knowledge necessary in science, are likely to experience difficulties to find that science is fun, exciting and meaningful.

Results of behavioral challenge rankings faced by new teachers in Saudi Arabia did not coincide with those reported by Owaidat and Hamdi (1997). In their work, Owaidat and Hamdi 
revealed that the most frequently mentioned behavioral challenges were arguments and fights between students; attempts of cheating during examinations and tests; and students arriving late for morning classes.

In this study, the classroom behavioral challenges encountered by new science teachers in their classroom were also analyzed by investigating the effect of new science teacher gender, school levels and teaching experiences. Male and female new science teachers have identified student absenteeism as the most important challenge encountered in their classrooms. However, their second and third most important behavioral classroom challenges choices were different. For Female new science teachers, working with students who ignore teacher instructions and who come late to science lessons were ranked second and third most important behavioral classroom challenges, respectively. While, their male colleagues put student lack of student readiness to learn science and student indifference to science lessons to the second and third place of most important behavioral classroom challenges. The t-test and confidence interval of the mean differences results showed significant differences in the perception of two behavioral classroom challenges between men and women new science teachers: student noncompliance and student lateness to science lessons. In contrast to female science teachers, male science teachers gave lower rankings to the challenges related to students ignoring instructions, orders and comments and coming late to their science class.

The findings revealed that first, second and third year science teachers, who participated in the study, ranked differently the behavioral challenges encountered in their classrooms. Firstyear science teachers perceived the following challenges as their top four challenges: excessive absences, negative ideas about science, student indifference to science lessons and inappropriate school supplies. Like first-year science teachers, third-year science teachers have selected 
student excessive absences as the most important classroom challenge followed by lack of motivation to learn science, lack of readiness to learn science and student indifference to science lessons. The top three most important behavioral challenges faced by second year science teachers were student lack of readiness to learn science, student indifference to science lessons and inappropriate school supplies. The results of a one-way ANOVA showed that there were no significant differences among first, second and third year science teachers in the behavioral challenges that they faced.

The descriptive statistics of mean and standard deviation for the effect of school level of new science teachers on behavioral challenges showed that elementary and high school science teachers gave the highest challenge rankings to excessive school absences. Middle school science teachers ranked excessive school absences in the third place of their challenges preceding by challenges related to student lack of readiness to learn science and cheating attempts during tests or examinations. Three further challenges were featured in the top four challenges faced by high school science teachers: student indifference to science lessons, lack of readiness to learn science and inappropriate school supplies. The top challenges faced by elementary school teachers, in addition to school absences challenge are : students lack of motivation to learn science; unwillingness to participate in classroom activities and turning the assignments in after deadline. The results of a one-way ANOVA suggest that there were significant differences among elementary, middle and high school new science teachers in the behavioral challenges that they faced.

When the interactions between new science teacher gender and years of experience were looked at, it was determined that first and third year female science teachers were facing the highest level of behavioral challenges in their classroom. Student absenteeism, negative 
conceptions about science and indifference to science lessons were perceived by the first-year female science teachers as their top three most important behavioral challenges. Like first-year female science teachers, third-year female science teachers were upset the most by their students who were missing a lot of science classes, not following instructions and lacking motivation to learn science. The results of the two- way ANOVA showed that the main effect of new science teacher gender, main effect of new science teacher years of experience and the interaction effect between new science teacher gender and years of experience were not statically significant on the level of behavioral classroom challenges.

In the interactional effect between new science teacher gender and school level, it was shown that female science teachers working in the middle schools were struggling the most with classroom behavioral challenges. These challenges were excessive student absenteeism, student ignoring teacher instructions, orders and comments and students interrupting one another during science lesson. The two- way ANOVA results revealed a significant main effect for school level for almost all behavioral challenges and a significant interaction effect between new science teacher gender and new science teacher school level for challenge related to students interrupting each other during science lesson.

When analyzing the interactions between new science teacher school level and years of experience, middle school beginning science teachers in their first two years were identified as the ones facing the highest level of behavioral challenges in their classroom. The results of the two- way ANOVA indicated that there was a significant main effect for new science teacher school level for all behavioral challenges and a significant interaction effect between new science teacher school level and new science teacher experience for challenge related to the lack 
of concern in performance of science activities and homework.

However, the findings of behavioral challenge rankings in relation to gender, school level and years of teaching experience were different from those of Al-Amarat (2011) research work. The results reported by Al-Amarat indicated that there were no significant differences among gender, school level and teaching experience in the behavior challenges that faced teachers at the public schools in Tafila province, Jordan. His research work also revealed that there was significant interaction effects among gender, school level and teaching experience.

\section{Beliefs and Supports}

In this study, qualitative research method was used to examine the views, perceptions and beliefs of new science teachers about effective science teaching and investigate the amount of support they receive in their teaching practice. The narratives of nine new science teachers, reported in the study, identified several instructional approaches of effective science teaching that were grouped in five categories. These categories included characteristics of effective science teaching related to (a) Identify and teach the core scientific ideas, (b) connecting science content with students' interests and real life issues, (c) using inquiry practices and getting hands on experiences, (d) Cooperative and collaborative learning, and (e) providing students with feedback by using multiple assessment methods.

Two of the novice science teachers highlighted the importance of the use of lectureexplanation techniques to promote students active engagement by fostering enthusiasm and a motivation for learning, stimulating further learning and thinking and challenging problem solving skills. Another new science teacher describe effective science teaching as the use of classroom activities that connect the content of science instruction to the students' prior knowledge, student interests, the real world applications and with other subjects. Four of the new 
science teachers, defined teaching science effectively as teaching science through science inquiry, direct observation and experimentation. The science teachers engaged the students in scientifically-orientated questions. The students were required to formulate explanations from evidence in responding to questions. The hands-on learning activities were used to help students to connect explanations to scientific knowledge. A new science teacher perceived the cooperative and collaborative learning approach as an effective science teaching strategy. In the collaborative learning environment, the students were arranged into different groups and work together on various science activities. Students of a same group, by talking among themselves, were exposed to diverse viewpoints and create their own conceptual frameworks. The participation of a student in group work in a science classroom is the key ingredient of student learning science success. Another new science teacher described the use of multiple assessment methods through effective feedback to ensure that students are learning science concepts and evaluation of the effectiveness of a teaching method. Prior to instruction of new science concept, science teachers assess the students' prior knowledge and skills in order to identify student weaknesses, adjust the curriculum and the pace of the course. During the science learning process, student learning is monitored using some assessment procedures to provide ongoing feedback that can be used by science teachers to modify teaching and learning activities. Finally, at the end of an instructional unit, student learning is evaluated by comparing it against some standard.

Results from the beliefs that hold these new science teachers in Al Jouf about effective science teaching fit more compatibly with a longitudinal study performed by Davis (2008). Her work has revealed five distinguishable conceptions of effective science teaching by following six teachers in their early years of teaching. These beliefs involved: determining learning goals 
and designing instructions to meet those goals, strengthening understanding of students using experience, emphasizing inquiry- based learning; combining hands-on activities and reading, and improving general citizen and learner skills.

Analyses of the semi-structured interviews of new science teachers highlighted the lack of support available to new science teachers. In fact, at the early stage of their career, beginning science teachers face many challenges but they usually get little or no support. In this study, the beginning science teachers listed five areas where schools can provide more or better support to them to become competent and effective teachers. These areas were: New teacher orientation programs, mentoring programs, curriculum and lesson planning, classroom management and discipline, and professional development programs.

These beginning science teachers asked their schools to improve the efficiency and effectiveness of new teacher orientation program. More than ever, attending effective orientation programs must provide opportunities for new science teachers to feel accepted by the school, understand the norms and values of the workplace, interact with colleagues, increase the potential for success and equip them with the skills they need to start the school year. New science teachers also need the support of more-experienced colleagues to battle the feeling of isolation and loneliness at their workplaces and reduce the stress. Establishing a successful mentoring program for science teachers that are new in the profession can lead to improve their personal and professional well-being. Moreover, supporting beginning science teachers with a complete and well-developed curriculum materials with detailed sequence of teaching procedures can help them to develop the necessary knowledge and skill to figure out how to plan and design the science course content effectively. The novice science teachers, who participated in the study interviews, admitted that they need support and help in dealing with classroom 
behavioral challenges. School principals, administrators and veteran teachers can offer constructive advice and share their classroom management tricks with the new teachers to help them gain control over their classroom and improve the learning atmosphere. The school leadership must also offer a wider support system to promote the growth and development of their novice teachers and make them effective teachers. Schools in Saudi Arabia were expecting to implement comprehensive, coherent in-service training programs and professional development program for all new science teachers. This type of support can enhance the beginning teacher abilities to teach science effectively to students.

The findings from the present study about new science teacher support were in reasonable agreement with various studies from the review of literature. Darling-Hammond (1984), Johnson (1990) and Ladd (2011) found that teacher' job satisfaction, performance, stated career intentions and plans were strongly related to the school social organization and climate and types of support that they received from the school. Louis, Kruse and Marks (1996) and Weiss (1999) suggested that schools must design and provide support for beginning teachers through high quality mentoring, induction and professional development programs.

\section{Conclusions}

Influenced by their beliefs and perceptions of effective science teaching, beginning science teachers pursued course of actions in their teaching practices that can help them to become effective science teachers. In this study, nine new science teachers in Al Jouf expressed diverse opinions concerning effective science teaching practices. Five of those practices were highlighted: (a) Identify and teach the core scientific ideas, (b) connecting science content with students' interests and real life issues, (c) using inquiry practices and getting hands on experiences, (d) Cooperative and collaborative learning, and (e) providing students with 
feedback by using multiple assessment methods. While many beginning science teachers have good beliefs and perceptions of effective science teaching practices, their limited teaching experience may lead them to experience challenges in teaching science.

In our study, female and male science teachers in AL Jouf, with less than three years of experience working with elementary, middle and high school students face a variety of academic and behavioral challenges in their current job.

The top three academic challenges faced by these new science teachers include: poor quality of teacher preparation programs, absence of appropriate school equipment and facility and lack of classroom materials and instructional supplies.

Another common challenge encountered by the novice science teachers, who participated in the study, were associated with the classroom management. Excessive student absenteeism, student readiness to learn science deficiencies and student lack of interest in science were the three most behavioral challenges encountered by these beginning science teachers in the province of Al Jouf.

All of these academic and behavioral challenges could be viewed as obstacles to the implementation of successful education in Saudi Arabia. Knowing about the most significant academic and behavioral challenges can prepare science teacher candidates to confront and overcome their frustrations and stress as they learn how teach effectively.

Despite the numerous challenges faced by new science teachers, they received little to no support from their schools. There are many ways that schools can provide more or better support to novice science teachers to help them improve their teaching practices and to become highly effective teachers. In this study, beginning science teachers were expected to receive a welldesigned and implemented support in these areas of need: effective new teacher orientation 
programs, successful mentoring programs, complete and well-developed curriculum materials with detailed sequence of teaching procedures, better classroom management, comprehensive, coherent in-service training programs and professional development program.

Saudi Arabia government and policy makers, school principals and administrators, students and their parents can take action to address the academic and behavioral challenges faced by new science teachers. The Saudi Arabia government needs to set science teacher certification and licensure requirements for all science teacher candidates, improve the quality of science teacher training programs and build well-equipped science laboratories for public schools. School principals can provide sympathy and perspective, offer advice and design various types of support to help new science teachers in dealing with personal, emotional, classroom management and academic teaching challenges. Students' parents can also help new science teachers do their demanding job effectively by filling their child with a love for learning science, teaching respectful behavior and listening skills to their children and building relationship with their children teachers. In similar fashion, students who are responsible for their own science learning can help decrease the novice teacher burnout and keep the teacher's focus on teaching science effectively.

Academic and behavioral classroom challenges faced by new sciences teachers can be overcome by expanding and strengthening the cooperation between the key actors of Saudi Arabia education system: Saudi Arabia government and policy makers, school principals and administrators, students and their parents. In sum, the study has implications for enhancing the overall quality of science education and student learning in the Kingdom of Saudi Arabia.

\section{Implications}

The findings from this study can help Saudi Arabia government, school principals, 
leaders and administrators to better understand and address academic and behavioral challenges that new science teachers faced in their daily professional life. The implications for research are connected to the roles and responsibilities of key actors in the kingdom of Saudi Arabia education. These actors are: government and policy makers, school principals and administrators, students and their parents.

\section{Saudi Arabia Government}

Their participation and active involvement is expected to improve education and make schools better. The Saudi Arabia government can play a significant role in new science teacher education by making teacher preparation their top priority and building well-equipped science laboratories for public schools. It can help ensure that all new science teachers have a quality education experience in their teacher preparation programs. The Saudi Arabia government need to take the lead for promoting effective science teaching at every school level. Setting teacher certification and licensure requirements for science teacher candidates and improving the quality of science teacher training program are important first steps toward the overall quality of education and student learning. It is critically important to establish clear standards about the content and outcomes of teacher preparation program so that beginning new science teachers were ready to practice independently. Offering better preparation programs to science teacher candidates is an important strategy to further build teaching effectiveness across the country. By investing in school science laboratories, equipment and supplies, the Saudi Arabia government give teachers and students to effectively teach and learn science.

\section{School Principals and Administrators}

As the primary leader in a school building, a school principal is responsible for managing daily school activities and the major administrative tasks, knowing and supporting curriculum 
standards, evaluating teachers' performance, handling student discipline, being in touch with students' parents and community members, and maintaining a safe and positive learning environment for students. Moreover, the school principal assembles a hiring team to recruit and secure effective and good teachers. Although school principals have many responsibilities, they

must always highly prioritize the call to support, guide and mentor beginning teachers. After new teachers are hired and placed in their areas of expertise, principals may clearly explain to them school expectations, policies and procedures. At the opening of school year, principals must provide an effective orientation program and needed resources and supplies for all new teachers. As the school year progresses, school principals may use different ways of accommodating the individual needs of novice teachers. They can also help the beginning teachers by establishing a strong working relationship with them and matching them with more experienced teachers. To support new teachers, principals need to encourage them to participate in professional program developmental activities with induction and mentoring program.

\section{Students' Parents}

Parents are encouraged to actively participated in their children's development and educational progress and have regular communications with their children's schools. Through reminders and guidance, parents can help their children to take charge of their learning. Parents also need to demonstrate to their children how much they value education in their house including the importance of regular school attendance. The desire for their children to succeed has launched parents to monitor their children regular school attendance and punctuality. A vital part of students' parental role is to teach their children good behavior for learning. Good behavior for learning is showing respect to the teachers, school staff and other students, following directions and being motivated to learn. 


\section{Students}

School settings offer a supportive environment in which students learn important habits and develop into autonomous and responsible learners. Students take ownership of their own learning in school and in life as they become more and more responsible. Responsible students make choices and take actions to help them achieve their educational goals. They attend and participate in classes and science labs, and prepared to learn new science concepts. Responsible students are engaged learners who are interested and highly motivate to learn science. They also do not allow negative behavior to impact their academic career.

\section{Further studies recommendations}

The research that has been undertaken for this dissertation has highlighted the academic and behavioral challenges that science teachers faced in their first three years of teaching in Al Jouf. This study involved 49 new science teachers who were surveyed and 9 who were interviewed in the traditional face- to-face setting. All the participants were from the province of Al Jouf. Future studies could further investigate similar topics with larger and random samples. The sample should include randomly chosen new science teachers for all the 13 provinces of Saudi Arabia.

In addition, the sample within each demography category should be equal in size. Therefore, the sample should include the same number of male and female participants, equal numbers of elementary, middle and high school novice science teachers, and also the same number of first, second and third year science teachers. There may be other demographic, personal and emotional characteristics that could have some impact as science teachers face challenges in their new workplace. Therefore, these other characteristics such as new science teachers school location, types of teacher preparation programs, motivations, science subject 
matter knowledge and types of students in the classroom could be additional research areas to consider for further research.

For future studies, students, veteran science teachers and school adminstrators and principals could be asked to isolate the challenges they believe new science teachers are facing. Students could provide feedback on the quality of teaching of their new science teachers. In addition, veteran science teachers can share and discuss their experiences about their first years in teaching. Working with new science teachers, school adminstrators and principals get to know them and identified their needs and challenges. For this reason, school adminstrators and principals design adequate support for novice teachers and help them to develop into highly effective classroom educators. The perceptions of students, veteran science teachers, school adminstrators and principals about the challenges faced by new science teachers should be considered in future research.

A final recommendation for future research is to investigate science teachers with more than three years of teaching to determine if the academic and behavioral challenges faced in their early years in classroom persist. This future study is expected to provide the opportunity to understand when the academic and behavioral challenges are no longer a concern to them. 


\section{REFERENCES}

Absenteeism hits 100\% ahead of Haj holidays. (2012, October 18). Saudi Gazette.

Retrieve from:

http://www.saudigazette.com.sa/index.cfm?method=home.regcon\&contentid=20121018140008

Achinstein, B. (2006). New teacher and mentor political literacy: reading, navigating and transforming induction contexts. Teacher and Teaching: Theory and Practice, 12(2), 123-138.

Al-Amarat, M.S. (2011). The classroom problems faced teachers at the public schools in Tafila province, and proposed solutions. International Journal of Education Science, 3 (1): 37-48.

Alexander, P.A., Jetton, T.L., \& Kulikowich, J.M. (1995). Interrelationship of knowledge, interest and recall: Assessing a modain of domain learning. Journal of Educational Psychology, $87,559-575$.

Alghamdi, A. H., \& Al-Salouli, M.S. (2012). Saudi elementary school science teachers' beliefs: Teaching science in the new millennium. International Journal of Science and Mathematics Education, $11: 501-525$.

Allinder, R.M. (1994). The relationship between efficacy and the instructional practices of special education teachers and consultants. Teacher Education and Special Education, 17, 86-95.

Artiles, A.J., \& Trent, S.C. (1997). Forging a research program on multicultural preservice teacher education: A proposed analytic scheme. In J.W., Lloyd, E.J. Kameenui, and D. Chard (Eds.), Issues in educating students with disabilities (pp. 275-304). Hillsdale, NJ: Lawrence Erlbaum.

Alsuiadi, F. (2015). Effect of the school facilities factor and sport activities factor on parents in terms of private and public school choice at Riyadh City Saudi Arabia. Universal Journal of Educational Research 3(12): 1054-1069.

Ball, D.L., \& Cohen, D.K. (1996). Reform by the book: What is-or might be-the role of curriculum materials in teacher learning and instructional reform?. Educational Researcher, 25(9),6-8,14.

Ball, D.L., \& Feiman-Nemser, S. (1988). Using textbooks and teachers' guides: A dilemma for beginning teachers and teacher educators. Curriculum Inquiry, 18(4), 401-422.

Bandura, A. (1977). Self-efficacy: Toward a unifying theory of behavioral change. Psychological Review, 84, 191-215.

Bandura, A. (1997). Self-efficacy: The exercise of control. New York: W.H. Freeman and Company. 
Barbar, S.A. et al. (2001). Design and building an online community: The struggle to support sociability in the inquiry learning forum. Educational Technology Research and Development, 49 (4),71-96.

Barrow, L.H. (1991). Evaluation of science laboratories in the middle schools of four educational districts in Saudi Arabia. PhD. Thesis, University of Missouri, Columbia.

Bartell, C.A. (2005). Cultivating high-quality teaching through induction and mentoring. Thousand Oaks, CA: Corwin.

Bergin, D.A.(1999). Influences on classroom interest. Educational Phycologist, 34(2), 87-98.

Bobbitt, S .A, Leich, M.C., Whittener, S.D., \& Lynch, H.F. (1994). Characteristics of stayers, movers, and leavers: Results from the teacher follow-up survey: 1991-1992. Washington, DC: National Center for Educational Statistics, U.S. Department of Education.

Boloz, S.A. et al. (1983). Combatting student absenteeism: strategies for raising attendance and achievement. Journal of American Indian Education. V22, 25-30.

Boyd, D., Grossman, P., Ing, M., Lankford, H., Loeb, S., \& Wyckoff, J. (2011). The influence of school administrators on teacher retention decisions. American Educational Research Journal, 48, 303-333.

Brannen, J. (2005). Mixed methods research: A discussion paper. ESRC National Centre for Research Methods NCRM Methods Review Papers, NCRM/005.

Britt, D.C. (1997). Perceptions of beginning teachers: Novice teachers reflect upon their beginning experiences. (ERIC Document Reproduction Service No. ED 415 218).

Broemmel, A.D., Swaggerty, E.A., \& Mcintosh, D. (2009). Navigating the waters of teacher induction: One beginning teacher's journey. The New Educator, 5, 67-80.

Brophy, J.E. (1982). How teachers influence what is taught and learned in classrooms. The Elementary School Journal, 83(1), 1-13.

Bryman, A. (2004). Social research methods (2 ${ }^{\text {nd }}$ ed.). New York: Oxford University Press.

Burley, W.W., Hall, B.W., Villeme, M.G., \& Brockmeier, L.L. (1991). A path analysis of the mediating role of efficacy in first-year teachers' experiences, reactions and plans. Paper presented at the annual meeting of the American Educational Research Association, Chicago, Il.

Cakiroglu, J. , Cakiroglu, E. \& Boone, W.J. (2005). Pre-service teacher self-efficacy beliefs regarding science teaching: A comparison of pre-service teachers in Turkey and the USA. Science Educator, 14, 31-40. 
Carter, W., Sottile, J.M., \& Murphy, Jr., (2002). Changing the "Ecosystem" of preservice math and science methods classes to enhance students' social, cognitive, and emotional development. (ERIC Reproduction Service Number: ED465523).

Cheng, M.H. (2002). Becoming confident teachers of science. Changes of science teaching efficacy beliefs. (ERIC Reproduction Service Number: ED463977).

Cimer, A. (2007). Effective teaching in science: A review of literature. Journal of Turkish Science Education, 4 (1), 20-44.

Coladarci, T. (1992). Teachers' sense of efficacy and commitment to teaching. Journal of Experimental Education, 60, 323-337.

Collins, A. (1990). Transforming the assessment of teachers: Notes on a theory of assessment for the $21^{\text {st }}$ century. Paper presented at the annual meeting of the National Catholic Education Association, Boston, MA.

Connelly, F.M., \& Dienes, B. (1982). The Teacher's role in curriculum Planning: A case study. In K. Leithwood (Ed.) Studies in curriculum decision making. Toronto: Ontario Institute for Studies in Education (E-Reserves)

Conway, P.F. (2001). Anticipatory reflection while learning to teach: From a temporally truncated to a temporally distributed model of reflection in teacher education. Teaching and Teacher Education, 17, 89-106.

Corcoran, E. (1981). Transition shock: The beginning teacher's paradox. Journal of Teacher Education, 32(3), 19-23.

Crawford, B.A. (1999). Is it realistic to expect a preservice teacher to create an inquiry-based Classroom?. Journal of Science Teacher Education, 10(3), 175-194.

Creswell, J. (1994). Research design: Qualitative and quantitative approaches. London: Sage.

Creswell, J. (2003). Research design: Qualitative and quantitative, and mixed methods approaches. Thousand Oaks. USA: Sage.

Darling-Hammond, L. (1984). Beyond the commission reports. The coming crisis in teaching. Santa Monica: RAND. (No. R-3117-RC).

Darling-Harmmond, L. (1997). Doing what matters most: Investing in quality teaching. New York: National Commission on Teaching and America's future.

Darling-Harmmond, L. (with Fickel, L., Macdonald, M., Merseth, K., Miller, L., Ruscoe, G., Silvernail, D., Snyder, J., Whitford, B.L., \& Zeichner, K.). (2006). Powerful teacher education: Lessons from exemplary programs. San Francisco: Jossey-Bass. 
Davis, E.A. (2006). Preservice elementary teachers' critique of instructional materials for science. Science Education, 90(2), 348-375.

Davis, E. A., Petish, D., \& Smithey, J. (2006) Challenges new science teachers face. Review of Educational Research, 76(4), 607-651.

Davis, E. A. (2008). Elementary teachers' ideas about effective science teaching: A longitudinal study. Proceedings ICLS 2008 Conference.

Deborah, D.L., \& McDiarmid G.W. The subject matter preparation of teachers. In. W.R. Houston (Ed.) Handbook for Research on Teacher Education. New York: Macmillan.

Decker, L.E., \& Rimm-Kaufman, S.E. (2008). Personality characteristics and teacher beliefs among pre-service teachers. Teacher Education Quarterly, 35, 45-64.

Dekalb, J. (1999). Student truancy. (Report No. EDO-EA-99-1). Washington, DC: Office of Educational Research and Improvement. (ERIC Document Reproduction Service No. ED429334).

Derry, S.M., \& Helmo-Silver, C. (2002). Addressing teacher education as a complex science: Theory-based studies within the STEP project. In P. Bell, R. Stevens and T. Satwicz (Eds.), ICLS (pp.611-615). Mahwah, NJ: Lawrence Erlbaum.

Drummond, R.J. (1991). Beginning teachers: What they have to say about their performance and Preparation. Florida: University of North Florida. (ERIC Document Reproduction Service No. ED 340 670).

Eick, C.J. (2002). Job sharing their first year: A narrative of two partnered teacher's induction into middle school science teaching. Teaching and Teacher Education, 18(7), 887-904.

Evans, E.D., \& Tribble, M. S. (1986). Perceived teaching problems, self-efficacy, and commitment to teaching among preservice teachers. Paper presented at the annual meeting of the American Educational Research Association, San Francisco.

Fajet, W., Bello, M., Leftwich, S.A., Mesler, J.L., \& Shaver, A.N. (2005). Pre-service teachers' perceptions in beginning education Classes. Teaching and Teacher Education, 21 (6), 717-727.

Fantilli, R. D. \& Mcdougall, D. E. (2009). A study of novice teachers: Challenges and supports in the first years. Teaching and Teacher Education, 25 ,814-825.

Fieman-Nemser, S. (2001). From Preparation to Practice: Designing a Continuum to Strengthen and Sustain Teaching. Teachers College Record, 103 (6), 1013-1055

Fieman-Nemser, S. (2003). What new teachers need to learn. Educational Leadership, 25-29. 
Fieman-Nemser, S., Carver, C., Schwille, S., \& Yuko, B. (1999). Beyond support: Taking new teachers seriously as learners. In M. Scherer (Ed.), A better Beginning: Supporting and Mentoring New Teachers (pp. 3-12). Alexandria, VA: Association for Supervision and Curriculum Development.

Fieman-Nemser, S., Carver, C., Katz, D., Schwille, S., Smith,E., \& Yuko, B. (2000). Beginning teacher induction: A study of three promising programs. Final report for the National Partnership for Excellence and Accountability (NPEAT). East Lansing, MI: Michigan State University, College of Education

Fishman, B. (2003). Linking on-line video and curriculum to leverage community knowledge. In J. Brophy (Ed.), Advances in Research on Teaching: Using Video in Teacher Education (vol.10,pp.201-234). New York: Elsevier.

Fisk, C.W. (1999). The costs and benefits of designing and implementing a portfolio based support and assessment system for beginning teacher. Paper presented at the annual meeting of the American Educational Research Association, Chicago.

Flores, M.A., \& Days, D. (2006). Context which shape and reshape new teacher's identities: A multi-perspective studies. Teaching and Teacher Education, 22(2), 219-232.

Fuller, F. (1969). Concerns of teachers: A developmental conceptualization. American Educational Research Journal, 6, 207-226.

Forbes, C.T., \& Davis, E.A. (2007). Beginning elementary teachers' beliefs about the use of anchoring questions in science: A longitudinal study. Science Education, 94(2), 365-387.

Ganser, T. (1999). Reconsidering the relevance of Veenman's (1984) meta-analysis of the perceived problems of beginning teachers. Paper presented at the meeting of American Educational Research Association, Montreal, Canada. (ERIC Document Reproduction Service No. ED 429 964)

Gencer, A.S., \& Cakiroglu, J. (2005). Turkish preservice science teachers' efficacy beliefs regarding science teaching and their beliefs about classroom management. Teaching and Teacher Education 23 (2007) 664-675.

Gerald, D.E., \& Hussar, W.J. (1998). Projections of education Statistics to 2008. Washington, DC: National Center for Educational Statistics, U.S. Department of Education, Office of Educational Research and Improvement.

Gezer, K., \& Bilen, K. (2007). Pre-service science teacher's views about characteristics of effective science teaching and effective science teacher. Journal of Applied Science, 7, 30313037.

Gibson, S., \& Dembo, M.H. (1984). Teacher efficacy: a construct validation, Journal of Educational Psychology, 76(4), 569-582. 
Gold, Y. (1996). Beginning teacher support: Attrition, mentoring, and induction. In J. Sikula, J. (Ed.), Handbook of research on teacher education. (pp.548-594).

Goodlad, J. (1984). A place called school: Prospects for the future. New York: McGraw-Hill. Goodlad, J. (1985). Improving the place called school: A conversation with John Goodlad. Educational Leadership. 16-19.

Grossman, P.L., \& Thompson, C. (2004). District policy and beginning teachers: A lens on teacher learning. Educational Evaluation and Policy Analysis, 26(4), 281-301.

Groves, R.M., Fowler, F.J., Couper, M.P., Lepkowski, J.M., Singer, E., \& Tourangeau, R. (2004). Survey methodology. Hoboken, NJ: John Wiley and Sons.

Guskey, T.R. (1981). Measurement of the responsibility teachers assume for academic successes and failures in the classroom. Journal of Teacher Education, 32(3), 44-51.

Hamdan, A. (2015). Challenges and constraints encountered by Saudi pre-service science teachers: a critical perspective. Learning and Teaching in Higher Education: Gulf Perspectives, $12(1)$.

Hammerness, K., Darling-Hammond, L., \& Bransford, J. (2005). How teachers learn and develop. In: Darling-Hammond, L. ed. Preparing teachers for a changing world: What teachers should learn and be able to do (pp. 358-389). San Francisco: John Wiley and Sons.

Hanna, G.S., \& Dettmer, P.A. (2004). Assessment for Effective Teaching Using ContextAdaptive Planning. Boston: Pearson Education.

Henson, R.K. (2001). The effects of participation in teacher research on teacher efficacy. Teacher and Teacher Education 17, 819-836.

Holubova, R. (2008). Project-based physics-physics teacher training course: Physics teacher for the $21^{\text {st }}$ century. The International Journal of Learning, 15(8), 253-262

Howe, K.R. (2009).Epistemology, methodology, and education sciences. Positivist dogmas, rhetoric and the education science question. Educational Researcher, 38(6), 428-440.

Howe, KR.(2013). Closing methodological divides: Toward democratic educational research (Philosophy and Education). Boston, MA: Kluwer.

Huberman, M. (1989). On teachers' careers: Once over lightly, with a broad brush. International Journal of Educational Research, 13 (4), 347-361.

International Assessment of Educational Progress. (1992). Learning Science. Princeton, NJ: Educational Testing Service.

Ingersoll, R.M. (2001). Teacher turnover and teacher shortage research: An organizational analysis. American Educational Research Journal, 38(3), 499-534. 
Jiffry, F. (2013). Saudi schools lack quality science and math teaching. Arab News.

Johnson, R.B., \& Christen, L.B. (2004). Educational research: Quantitative, qualitative, and mixed and approaches. Boston, MA: Allyn and Bacon.

Johnson, D.W., \& Johnson, R.T. (1999). Making cooperative learning work. Theory into Practice 38(2) 67-73.

Johnson, R.B., \& Onwuegbuzie, A.J. (2004). Mixed methods research: A research paradigm whose time has come. Educational Researcher, 33 (7), 14-26.

Johnson, S. M. (1990). Teachers at work: Achieving success in our schools. New York: Basic books.

Johnson, S.M., Kraft, M.A., \& Papay J.P. (2012). How context matters in high-need schools: The effects of teachers' working conditions on their professional satisfaction and their students' achievement. Teachers College Record, 114(10), 1-39.

Kagan, D.M. (1992). Implication of research on teacher belief. Educational Psychologist, 27(10), 65-90.

Kaltakci, D., \& Eryilmaz, A. (2008). Diagnosis of pre-service physics teachers' conceptions in geometric optics.

Kauchack, D., \& Eggen, P.D. (1988). Learning and Teaching : Research-based Methods ( $3^{\text {rd }}$ ed). Boston: Allyn and Bacon.

Kaufman, D. et al. "Lost at Sea" New Teachers' experiences with curriculum and assessment. Teachers College Record, 104, 273-300.

Kesidou, S., \& Roseman, J., E. (2002). How well do middle school science programs measure up? Finding from Project 2061's curriculum review. Journal of Research in Science Teaching, $39,522-540$.

Kozinetz, C.A. (1995). Using administrative data to identify elementary schools at increased risk for student absences. Journal of School Health. 65, 262-265.

Kvale,S. (1996). Interviews: An introduction to qualitative research interviewing. Thousand Oaks: Sage.

Ladd, H. (2011). Teachers' perceptions of their working conditions: How predictive of planned and actual teacher movement?. Educational Evaluation and Policy Analysis, 33, 235-261.

LaTurner, R. J. (2002). Teachers' academic preparation and commitment to teach math and science: Teaching and Teacher Education: An International Journal of Research and Studies, 18, 653-663. 
Le Maistre, C., \& Pare, A. (2010). Whatever it takes: How beginning teachers learn to survive. Teaching and Teacher Education, 26(3), 559-564.

Levine, D., \& Lezotte, L. (1990). Unusually effective schools: A review and analysis of research and practice. Madison, WI: The National Center for Research and Development.

Lincoln, Y.S., \& Guba, E.G. (1985). Naturalistic inquiry. Beverly Hills, CA: Sage.

Liston, D., Whitcomb, J., \& Borko, H. (2006). Too little or too much: Teacher preparation and the first of teaching. Journal of Teacher Education 57(4), 351-358.

Liu, S.X., \& Meyer, J.P. (2005). Teachers'perceptions of their jobs: A multilevel analysis of the teacher follow-up survey for 1994-1995. Teachers College Record, 107 (5), 985-1003.

Louis, Kruse, \& Marks (1996). Schoolwide professional development. In F. Newmann and Associates, Authentic achievement: Restructuring schools for intellectual quality, 170-203. San Francisco: Jossey-Bass.

Mandel, S. (2006). What new teachers really need: What first-year teachers say they need to survive on the job is often markedly different from what school provide. Educational Leadership, 63(6), 66-69.

Many schools suffer from severe teacher shortage. (2012, April 14). Arab news. Retrieve from: http://www.arabnews.com/node/410971.

Mayring, P. ( 2000). Quantitative content analysis. Available at http://www.quantitativeresearch.net/fqs-texte/2-00/2-00mayring-e.htm

Mayring, P. (2007). Introduction: Arguments for mixed methodology. In P. Mayring, G. L. Huber, L. Gurtler and M. Kiegelmann (Eds.), Mixed methodology in psychological research (pp. 1-4). Rotterdam/Taipei: Sense Publishers.

McKinsey (2007). How businesses are using web 2.0: A Mckinsey global study. The Mckinsey Quarterly Report McKinsey and Company.

Meister, D. G., \& Melnick, S. (2003). National new teacher study: Beginning teachers concerns. Action in Teacher Education, 24(4), 87-94.

Metropolitan Life Co. (1985). Former teachers in America. New York: Author.

Mingers, J. (2001). Combining IS research methods : Towards a pluralist methodology. Information Systems Research, 12(3), 240-259.

Minor, L.C., Onwuegbuzie, A. J., \& Witcher, A.E. (2000). Preservice teachers' perceptions of characteristics of effective teachers: A multi-stage mixed methods analysis. Paper presented at the Annual Meeting of the Mid-South Educational Research Association, Lexington, KY. 
Monk, D. (1994). Subject area preparation of secondary mathematics and science teachers and student achievement. Economics of Education Review, 13(2), 125-145.

Moreira, S.J. (2002). Student perceptions of good teaching practices. Ph.D Thesis, University of Pacific Stockton, California.

Murnane , R. J., Singer, J. D., Willett, J. B., Kemple, J.J., \& Olsen, R. J. (1991). Who will teach?: Policies that matter. Cambridge: Harvard University Press.

Murphy, M.J., Hart, A.W., \& Walters, L.C. (1989). Satisfaction and intent to leave responses of new teachers in target populations under redesigned teacher work. A paper presented at the annual meeting of the American Educational Research Association, San Francisco.

National Research Council. (2010). Preparing teachers: Building evidence for sound policy. Committee on the study of teacher preparation programs in the United States, division of behavioral and social sciences and educations (pp. 232). Washington, D.C. : National Academy Press.

Newman, I., \& Benz, C.R. (1998). Qualitative-quantitative research methodology: Exploring the interactive continuum. Carbondale: University of Illinois Press.

Ndaayezwi, D. (2003). Parental involvement: The effect of home visits on academic achievement, discipline, and attendance of high-school students (Unpublished doctoral dissertation), Regent University, Virginia Beach, VA.

Neathery, M.F. (1997). Elementary and secondary students' perceptions toward science: Correlations with gender, ethnicity, ability, grade, and science achievement. Electronic Journal of Science Education, 2 (1).

Nkwi, P., Nyamongo, I., \& Ryan, G. (2001). Field research into socio-cultural issues: Methodological guidelines. Yaounde, Cameroun, Africa: International Center for Applied Social Sciences, Research and Training/ UNFPA.

Oberg, K. (1972). Culture shock and the problem of adjustment to new cultural environments. In D. Hoopes (Ed.), Readings in Intercultural Communications. Pittsburgh: Pittsburgh Intercultural Communications Network of the Regional Council for International Education.

Odden, A., \& Kelley, C. (1997). Paying teachers for what they know and do: New and smarter compensation strategies to improve schools. Thousand Oaks, CA: Corwin Press.

Owaidat, A., \& Hamdi, N. (1997). Behavioral problems of male students in $8^{\text {th }}, 9^{\text {th }}$ and $10^{\text {th }}$ class in Jordan, and variables related to those problems. Journal of Dirasat, 24(2), 298-315.

Pajares, M.F. (1992). Teachers' beliefs and educational research: cleaning up a messy construct. Review of Educational Research, 42(3), 307-333. 
Porter, A.C., \& Brophy, J. (1988). Synthesis of research of good teaching: Insights from the work of the Institute for Research on Teaching. Educational Leadership, 45, 74-85.

Pugach, M.C. (1992). Unchartered territory: Research on the socialization of special education. Teacher Education and Special Education 15,133-147.

Quinn, T. (2002). Succession planning: Start today. Principal Leadership, 3(2), 24-28.

Raphael, J., Tobias, S., \& Greenberg, R. (1999). Research experience as a component of science and mathematics teacher preparation. Journal of Science Teacher Education, 10(2), 147-158..

Reeves, C.K., \& Kazelkis, R. (1985). Concerns of preservice and in service teachers. Journal of Educational Research 78(5), 267-271.

Reiman, A.J., \& Paramore, B.M. (1994). First-year teachers' assignments, expectations, and development: A collaborative investigation. In M. O’ Hair and S. O’Dell, (Eds), Teacher Education Year Book II (pp.120-134). Orlando: Harcourt Brace Jovanovich.

Rim-Kauffman, S.E et al. (2006). TBQ-Sort: A Measure of teachers' priorities and beliefs in relation to disciplinary practices, Teaching practices, and beliefs about children. Journal of School Psychology, 44,141-165.

Romano, M.,\& Gibson, P. (2006). Beginning teacher successes and struggles: An elementary teacher"s reflections on the first year of teaching. The Professional Educator, 28(1).

Sabar, N. (2004). From heavy to reality through crisis: Novice teachers as migrants. Teaching and Teacher Education, 20, 145-161.

Schlechty, P., \& Vance, V. (1983). Recruitment, selection, retention: The Shape of the teaching force. Elementary School Journal, 83(4), 469-487.

Schwarz, C.V. , Gunckel, K. L., Smith, E. L., Covitt, B. A., Bae, M.-J., Enfield, M., et al. (2008). Helping elementary preservice teachers learn to use curriculum materials for effective science teaching. Science Education, 92 (2), 345-377.

Segall, W.E., \& Wilson, A.V. (1998). Introduction to education: Teaching in a diverse society. Upper Saddle River, NJ: Merill.

Shannag, Q.A., Tairab, H., Dodeen, H., \& Faisal, A.F. (2013). Linking teachers 'quality and student achievement in the Kingdom of Saudi Arabia and Singapore: The impact of teachers' background variables on student achievement. Journal of Baltic Science Education, 12 (5), 652665

Sheehan, M. (2010). Identification of difficult topics in the teaching and learning of Chemistry in Irish schools and the development of an intervention programme to target some of these difficulties, Ph.D. ed., University of Limerick. 
Shulman, L.S. (1986). Those who understand: Knowledge growth in teaching. Educational Researcher, 15(2), 4-14.

Shulman, L.S. (1987). Knowledge and teaching: Foundations of the new reform. Havard Education Research, 57(1), 1-22.

Sieber, S. D. (1973). The integration of fieldwork and survey methods. American Journal of Sociology, 73, 1335-1359.

Smith, W., \& Andrews, R. (1990). Instructional leadership: How principals make a difference. Alexandria, VA: Association for Supervision and Curriculum Development.

Snow,C.E, Griffin, P., \& Burns, M.S.(Eds.) (2006). Knowledge to support the teaching of reading: Preparing teachers for changing world. San Francisco, CA: Jossey Bass.

Stern, L., \& Roseman, J.E. (2004). Can middle school science textbooks help students learn important ideas? Findings from Project 2061's curriculum evaluation study: Life science. Journal of Research in Science Teaching:, 41(6),538-568.

Stipek, D., Givvin, K., Salmon, J., \& MacGyvers, V. (2001). Teachers' beliefs and practices related to mathematics instruction. Teaching and Teacher Education. 17(2), 213-226.

Stuart, C., \& Thurlow, D. (2000). Make it their own: Preservice teachers' experiences, beliefs, and classroom practices. Journal of Teacher Education 51(2), 113-121.

Tabachnik, B.R., \& Zeichner, K.M. (1999). Idea and action: Action research and the development of conceptual change teaching of science. Science Education, 83(3),309-322.

Tashakkori, A., \& Teddlie, C. (2003). Handbook of mixed methods in social and behavioral research. Thousand Oaks, CA: Corwin.

Thomas, R.M. (2003). Blending qualitative and quantitative research methods in theses and dissertations. Thousand Oaks, CA: Corwin.

Titus, P.A., Gremler, D.D. (2010). Guiding reflective practice: An auditing framework to assess teaching philosophy and style. Journal of Marketing Education, 32 (2), 82-196.

Tobias, S. (1994). Interest, prior knowledge, and learning. Review of Educational Research, 61, 37-54.

Tosun, T. (2000). The beliefs of preservice elementary teachers toward science and science teaching. School Science and Mathematics, 100 (7), 374-379.

Toumi, H. (2014). School principals face axe over absenteeism. Gulfnews.com. 
Ulvik, M.,Smith, K., and Helleve, I. (2009). Novice in secondary school-The coin has two sides. Teaching and Teacher Education, 25, 835-842.

United Nations Development Programme (UNDP) and Kingdom of Saudi Arabia, Ministry of Economy and Planning (2003). Kingdom of Saudi Arabia: Human development report. New York: UNDP. Available from:

http://planipolis.iiep.unesco.org/upload/Saudi\%20Arabia/Saudi\%20Arabia\%20HDR\%202003\% 20en.pdf.

UNESCO Institute of Statistics (2006). Global education digest 2006. Comparing education statistics across the world. Retrieve from: www.uis.unesco.org/Library/Documents/ged06-en.pdf

United States Department of Education (1996). The problem of truancy in America's communities: Washington, DC: Government Printing Office.

United States Department of Justice (2001). Truancy reduction: Keeping students in school. Office of Justice Programs. Office of Juvenile Delinquency Prevention.

Vasquez, J. A. (2008). Tools and traits for highly effective science teaching, K-8. Portsmouth, NH: Heinemann.

Vaughn, Bos, \& Schum, (1997). Teaching mainstream, diverse, and a risk students in the general education classroom. Boston: Allyn and Bacon.

Veenman, S.A. (1984). Perceived problems of beginning teachers. Review of Educational Research, 54, 143-178.

Veenman, S.A. (1987). On becoming a teacher: An analysis of initial training. Paper presented at the conference on education of the world Basque Congress.

Weinstein, C. (1989). Teacher education students' preconception of teaching. Journal of Teacher Education, 40(2), 53-60

Weinstein, C. (1990). Prospective elementary teacher's beliefs about teaching: Implications for teacher education. Teaching and Teacher Education, 6(3), 279-290.

Weiss, I.R. (1987). Report of the 1985-86 national survey of science and mathematics education. Research Triangle Park, N.C.: Center of Educational Research and Evaluation.

Weiss, E. M. (1999). Perceived workplace conditions and first-year teachers' moral career choice commitment and planned retention: A secondary analysis. Teaching and Teacher Education, 15, 861-879.

Weld, J.D., \& French, D.P. (2001). An undergraduate science laboratory field experience for preservice science teachers. Journal of Science Teacher Education, 12(2), 133-142. 
Werneck, P. L. (1990). Alleviating teacher shortages through pension plan redesigned.

Retrieved from: http://www.nctr.org/pdf/tchrshortage.pdf.

Whitener, K.J., Gruber, K.J., Lynch, H., Tingos, K., Perona,M., \& Fondelier, H. (1997).

Characteristics of stayers, movers, and leavers: Results from the teacher follow-up survey: 199495. (Office of Educational Research and Improvement, NCES 97-450). Washington, DC: U.S. Department of Education.

Wong, H.K. (2004). Induction programs that keep new teachers teaching improving. NASSP bulletin, 88(638), 41-58.

Woodward, A., \& Eliot, D.L. (1990). Textbook use and teacher professionalism. In D.L. Elliot and A. Woodward (Eds.), Textbooks and schooling in the United States (89 ed., vol 1 pp. 1780193). Chicago: The University of Chicago Press.

Woolfolk, A.E., \& Hoy, W.K.( 1990). Prospective teachers 'sense of efficacy and beliefs about control. Journal of Educational Psychology, 82(1), 81-91.

Yee, S. M. (1990). Careers in the Classroom: When teaching is more than a job. New York: Teachers College Press.

Yesil-Dagli, U., Lake, V., \& Jones, I. (2005). Preservice teachers' beliefs about mathematics and science content and teaching. Journal of Research in Education, 21(2), 33-48.

Zamudio, G. (2004). Student mobility: the relationship between student population stability and academic achievement. (Unpublished doctoral dissertation), University of Arizona, Arizona. 
W. WestVirginiaUniversity.

COLLEGE OF EDUCATION AND HUMAN SERVICES

\section{APPENDIX A: Survey Cover Letter}

Dear Teacher,

I am a doctoral student at West Virginia University and preparing to conduct research for my study titled "Challenges faced by new science teachers in Saudi Arabia". I would like to invite you to participate in this research project by answering questions contained in the attached survey.

As part of the research study, new science teachers in Saudi Arabia will be surveyed to determine the challenges that they encountered in their profession. Understanding new science teachers' challenges is the first step in helping them to overcome the challenges. In addition, this study discusses appropriate supports and assistance that can be provided to the new science teachers. The study is being conducted to complete my dissertation.

The survey should take approximately fifteen minutes to complete. I would really appreciate if you could take time to complete the attached questionnaire and send it back to me. If you choose to participate in this study, your identity and confidentiality will be protected throughout the study. Individual responses to this survey are kept confidential and anonymous. Only aggregate responses to the survey are presented in the study results. Your participation is completely voluntary and you may withdraw at any time without penalty.

If you have any questions or concerns about this research project, please feel free to contact me by my email atsalman1021@hotmail.com or by telephone at 0507117110.

Thank you in advance for your help, time and assistance with this research project.

Sincerely,

Salman AlSharari

Doctoral Student

West Virginia University

DEPARTMENT OF CURRICULUM \& INSTRUCTION/ITERACY STUDIES

PO Bo: 6:22i602 Alen Hall

Morgantom, WW 265066122

Equa Oppontinaty / Attimative Action institution 


\section{APPENDIX B: Demographic Survey Questions}

\section{What is your gender?}

Male $\square$ Female

\section{What is your marital status?}

$\square$ single $\square$ married $\square$ widowed $\square$ divorced

3. What is your age?

$\square$ 21-25 years old $\square$ 26-30 years old $\square$ 31-35 years old $\square$ 36-40 years old $\square$ other

4. What is the highest education level you have completed?

$\square$ Bachelor Degree $\square$ Master Degree $\square$ some doctorate courses $\square$ Doctorate Degree

5. What was your major field of study?

$\square$ Elementary ed. $\square$ Middle School ed. $\quad \square$ science ed. $\square$ science $\square$ Other

6. Including the current school year, how many years of teaching experience do you have?

Between 0-1 years $\square$ Between 1-2 years $\square$ Between 2-3 years

7. What is your science class size?

10-19 students $\square 20-29$ students $\square 30-39$ students $\square$ 40-49 students $\square 50$ or more

8. Which best describes your current teaching level?

$\square$ elementary school $\square$ middle school $\quad \square$ high school

9. How many different science classes do you currently teach?
$\square 1$
$\square 2$
$\square 3$
$\square 4$
$\square 5$

10. What science class(es) are you teaching? (Check all that apply)

$\square$ general science $\square$ life science $\square$ physical science $\quad \square$ Earth science

$\square$ chemistry $\quad \square$ biology $\quad \square$ physics $\quad \square$ other

11. Which best describes your current school setting?
above average wealth
average wealth
below average wealth 
12. What is your overall level of satisfaction with your job as a teacher?

$\square$ Very dissatisfied $\square$ dissatisfied $\quad \square$ satisfied $\quad \square$ very satisfied

13. How much of the science instructional time (hours per week) your students spend doing a laboratory activity, investigation or experiment?

$\square$ 1 hour per week $\square 2$ hours per week $\square 3$ hours per week $\square 4$ hours per week

14. In your science class, what is the relative amount of time students work either individually or in pairs/small groups on assignments?
$\square 0 \%$
$\square 25 \%$
$\square 50 \%$
$\square 75 \%$
$\square 100 \%$ 


\section{APPENDIX C: Academic challenges Survey Questions}

For each question below, please mark one choice:

\begin{tabular}{|l|l|l|l|l|l|}
\hline Challenges of You as a Teacher & \multicolumn{5}{|l|}{} \\
\hline & $\begin{array}{l}\text { Major } \\
\text { Challenge }\end{array}$ & Challenge & $\begin{array}{l}\text { Moderate } \\
\text { Challenge }\end{array}$ & $\begin{array}{l}\text { Minor } \\
\text { Challenge }\end{array}$ & $\begin{array}{l}\text { No } \\
\text { Challenge }\end{array}$ \\
\hline 1. Teacher preparation program & & & & & \\
\hline $\begin{array}{l}\text { 2. Knowledge of science subject } \\
\text { matter }\end{array}$ & & & & & \\
\hline $\begin{array}{l}\text { 3. Effective use of different } \\
\text { teaching methods }\end{array}$ & & & & & \\
\hline $\begin{array}{l}\text { 4. Planning lessons and school } \\
\text { days }\end{array}$ & & & & & \\
\hline 5. Organization of class work & & & & & \\
\hline 6. Heavy teaching load & & & & & \\
\hline $\begin{array}{l}\text { 7. Determining learning level of } \\
\text { students }\end{array}$ & & & & & \\
\hline 8. Assessing students' work & & & & & \\
\hline $\begin{array}{l}\text { 9. Dealing with challenges of } \\
\text { individual students }\end{array}$ & & & & & \\
\hline 10. Classroom discipline & & & & & \\
\hline 11. Motivating students & & & & & \\
\hline 12. Salary and benefits & & & & & \\
\hline 13. School equipment and facility & & & & & \\
\hline 14. Materials and supplies & & & & & \\
\hline 15. Relations with colleagues & & & & & \\
\hline 16. Relations with administrators & & & & & \\
\hline $\begin{array}{l}\text { 17. Relations with student's } \\
\text { parents }\end{array}$ & & & & & \\
\hline $\begin{array}{l}\text { 18. Awareness of school policies, } \\
\text { rules and procedures }\end{array}$ & & & & & \\
\hline $\begin{array}{l}\text { 19. Burden of } \\
\text { administrative/clerical work }\end{array}$ & & & & & \\
\hline $\begin{array}{l}\text { 20. Opportunity to influence over } \\
\text { school decision making }\end{array}$ & & & & & \\
\hline $\begin{array}{l}\text { 21. Opportunity for professional } \\
\text { growth }\end{array}$ & & & & & \\
\hline $\begin{array}{l}\text { 22. Community recognition as a } \\
\text { professional }\end{array}$ & & & & & \\
\hline 23. Teacher job satisfaction & & & & & \\
\hline 24. Being accepted by students & & & & & \\
\hline 25. Understand teacher & & & & \\
\hline
\end{tabular}




\begin{tabular}{|l|l|l|l|l|l|}
\hline Challenges of You as a Teacher & \multicolumn{5}{|l|}{} \\
\hline & $\begin{array}{l}\text { Major } \\
\text { Challenge }\end{array}$ & Challenge & $\begin{array}{l}\text { Moderate } \\
\text { Challenge }\end{array}$ & $\begin{array}{l}\text { Minor } \\
\text { Challenge }\end{array}$ & $\begin{array}{l}\text { No } \\
\text { Challenge }\end{array}$ \\
\hline performance evaluation system & & & & & \\
\hline $\begin{array}{l}\text { 26. Please list any challenges you } \\
\text { encounter in the classroom }\end{array}$ & \multicolumn{4}{|l|}{} \\
\hline
\end{tabular}




\section{APPENDIX D: Behavioral challenges Survey Questions}

For each question below, please mark one choice:

\begin{tabular}{|l|l|l|l|l|l|}
\hline Student Behaviors as Challenges & \multicolumn{3}{|c|}{ Frequency } \\
\hline & $\begin{array}{l}\text { Major } \\
\text { Challenge }\end{array}$ & Challenge & $\begin{array}{l}\text { Occasionally } \\
\text { a Challenge }\end{array}$ & $\begin{array}{l}\text { Rarely a } \\
\text { Challenge }\end{array}$ & $\begin{array}{l}\text { Never a } \\
\text { Challenge }\end{array}$ \\
\hline $\begin{array}{l}\text { 1. Students do not appear ready to learn } \\
\text { science }\end{array}$ & & & & & \\
\hline $\begin{array}{l}\text { 2. Students have negative ideas about } \\
\text { science lessons }\end{array}$ & & & & & \\
\hline 3. Indifference to science lessons & & & & & \\
\hline $\begin{array}{l}\text { 4. Students do not have correct supplies } \\
\text { ready }\end{array}$ & & & & & \\
\hline $\begin{array}{l}\text { 5. Students ignore the teacher } \\
\text { instructions, orders and their comments }\end{array}$ & & & & & \\
\hline 6. Lack of motivation to learn science & & & & & \\
\hline $\begin{array}{l}\text { 7. Nonparticipation in classroom science } \\
\text { activities and labs }\end{array}$ & & & & & \\
\hline $\begin{array}{l}\text { 8.Attempts of cheating during tests or } \\
\text { examinations }\end{array}$ & & & & & \\
\hline $\begin{array}{l}\text { 9. Students are chatting among } \\
\text { themselves during science class }\end{array}$ & & & & & \\
\hline 10. Students interrupt others & & & & & \\
\hline 11. Excessive absences & & & & & \\
\hline 12.Students come late to science lessons & & & & & \\
\hline 13. Sleeping during science lessons & & & & & \\
\hline 14. Leaving class early & & & & & \\
\hline $\begin{array}{l}\text { 15. Playing and using mobile phones } \\
\text { during science class }\end{array}$ & & & & & \\
\hline $\begin{array}{l}\text { 16. Students reply to the teacher in the } \\
\text { impolite manner }\end{array}$ & & & & & \\
\hline $\begin{array}{l}\text { 17. Harassment and abuse of other } \\
\text { students }\end{array}$ & & & & & \\
\hline 18.Inapropriate out of seat behavioral & & & & \\
\hline $\begin{array}{l}\text { 19. Students do not complete science } \\
\text { assignments on time }\end{array}$ & & & & & \\
\hline $\begin{array}{l}\text { 20. Lack of concern in performance of } \\
\text { science activities and homework }\end{array}$ & & & & & \\
\hline $\begin{array}{l}\text { 21. Please list any behavioral challenges } \\
\text { encountered in science classes }\end{array}$ & & & & & \\
\hline
\end{tabular}




\section{APPENDIX E: Cover letter of invitation for interview}

Dear Teacher,

I would like to thank you for taking your valuable time to participate in the survey. The thoughts, feedback and input you provided on the survey are highly appreciated and will help me better understand the challenges faced by new science teachers in the Kingdom of Saudi Arabia.

To examine in depth the experience of science teachers in their new profession during their first three years in the Kingdom of Saudi Arabia, I would like to meet with you for a semi-structured interview. By participating to the interview, you have the opportunity to describe your experience as a science teacher, your school environment, and your experience with the use of curriculum and assessment materials and also to share your beliefs and opinions about effective science teaching.

The meeting will take place at your school or a mutually agreed place at your earliest convenience and should take approximately fifteen minutes. The interview will be voice taped so that I can carefully analyze the content of our conversation. After transcribing and analyzing the tapes, they will be destroyed.

If you decide to participate in this interview, your identity and confidentiality will be protected throughout the study. Your participation is completely voluntary and you may withdraw at any time without penalty.

If you have any questions or concerns about this research project, please feel free to contact me by my email atsalman1021@,hotmail.com or by telephone at 0507117110.

Thank you in advance for your help, time and assistance with this research project.

Sincerely,

Salman A1Sharari

Doctoral Student

West Virginia University

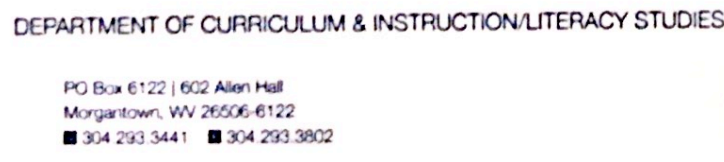

Equai Opontinity / Atlimative Action instrution 


\section{APPENDIX F: Semi-structured interview questions}

1. What science are you teaching?

2. How do you teach science?

3. How would you describe effective teaching of science?

4. What support do you receive in your science teaching?

5. What other comments would you like to add about science or science teaching? 


\title{
APPENDIX G: Semi-structured Interview Transcript
}

\author{
Hello, Mr. Kareem. My name is Salman and I am currently a doctorate candidate at West \\ Virginia University. I am working on a research project about the challenges faced by new \\ science teachers in Saudi Arabia. Thank you for your willingness to participate in the \\ interview. Please tell me, what science subjects do you teach?
}

It is a pleasure to meet you, Salman. I am teaching Earth Science.

By the way, what grade level do you teach?

I am a middle school teacher.

How long have you been teaching?

I am in my first year of teaching

Do you like teaching science?

Yes, I do. I am very passionate about science and love teaching science. I feel that I am competent and have good subject knowledge.

\section{How do you teach science to students?}

In my science classroom, I use the "learn by doing" approach for teaching my students. When introducing a new science topic, I start by first describing a new experience or activity to the students and then ask them to perform it either individually or in group. After experience or activity completion, students were asked to share among themselves their observations, results and reactions. The results shared by students were analyzed through discussions and looking at the experience. Then, students summarized what they have learned from the experience and formulate the concept. Finally, students were asked to implement or execute what they learned from the experience to similar or different situations.

\section{In your opinion, what constitutes effective teaching in science?}

In my opinion, learning by doing method is one of the best methods for teaching science because it provides opportunities for students to enhance and verbalize logical thoughts, develop psychomotor skills, compare experiences, summarize and evaluate their experiences, and utilizes the results in real life environment.

\section{What is the greatest challenge do you face?}

I am really struggling with classroom management. I am facing consistent student behavior challenge in my classroom and did not how to deal with the classroom management challenge. 
I was not able to control my class. It was difficult to achieve learning goals without good student discipline. Challenges in managing classrooms give me feelings of excessive stress and feelings of failure in my profession

\section{As a new science teacher, do you receive support and help from your school?}

The school principal often fails to intervene adequately to solve the classroom management issues. He was expected me to handle student discipline problems and was not ready to step in with support. Students with severe misbehaviors and habitual offenses in my class were sent to the office of the principal. After a few days, the defiant and disruptive students repeat their bad behavior in the class.

\section{Is there anything you would like to add?}

New teachers need significant support from the schools to be successful by improving their classroom management practices and skills. Classroom management and discipline is an important component of positive and successful science classroom.

\section{Thank you for taking time to speak with me.}

You are welcome and I wish you all the best in your studies. 